\title{
Seizing the Mobile Moment: Spectrum Allocation Policy for the Wireless Broadband Century
}

\author{
Charles M. Davidson ${ }^{\dagger} \&$ Michael J. Santorelli ${ }^{\ddagger}$
}

\section{INTRODUCTION}

Communications services have consistently played an important role in U.S. economic development. ${ }^{\prime}$ Characterized by economies of scale and exhibiting network effects, ${ }^{2}$ these services have welfare-enhancing benefits that spur in-

\footnotetext{
${ }^{\dagger}$ Director, Advanced Communications Law \& Policy Institute at New York Law School.

${ }^{\ddagger}$ Director, Advanced Communications Law \& Policy Institute at New York Law School. The authors thank Christopher Tsaganeas and Evan Barquist for their research assistance.

1 For example, the telegraph is often credited with laying the foundation for modern commerce. Robert Horwitz observed, "[t]he telegraph was instrumental in the rise of the large corporation. Instantaneous communication greatly lowered information and transaction costs for many firms, enabling them to widen their markets. This had the effect of increasing their size and scale...Geographically dispersed operations and agents could be brought under centralized supervision." ROBERT BRITT HORWITZ, THE IRONY OF REGULATORY REFORM 92-93 (Oxford Univ. Press 1989) [hereinafter IRONY OF REgUlatoRy REFORM]. More recently, innovation in the communications sector-e.g., widespread use of information technologies-has had a direct impact on facilitating rapid globalization of a number of key industries. See, e.g., MARTIN WOLF, Why GLOBALIZATION WORKS 119-120 (Yale Univ. Press 2004); ERIK BRYNJOLFSSON \& ADAM SAUNDERS, WIRED FOR INNOVATION: How Information TeChNology is Reshaping the Economy xi (MIT Press 2009) ("[I]nformation technology has been responsible, directly or indirectly, for most of the resurgence of productivity in the United States since 1995.").

2 See Lars-Hendrik Röller \& Leonard Waverman, Telecommunications Infrastructure and Economic Development: A Simultaneous Approach, 91 AMER. ECON. REV. 909, 911 (2001) ("One seemingly important characteristic of telecommunication technologies, which is not present in other types of infrastructure, is network externalities: the more users, the more value is derived by those users.").
} 
novation in other sectors by virtue of a spillover effect. ${ }^{3}$ While the full range of communications services has exhibited such impacts throughout the industry's long history, broadband, the newest of the communications technologies, has quickly become the most robust platform to facilitate economic development, enable new business models and stimulate innovation across innumerable sectors. $^{4}$

The recent economic downturn highlights the critical role broadband will play in the recovery and future gains of the U.S. economy. ${ }^{5}$ In early 2009 , at the trough of the recession, the U.S. Congress passed the American Recovery and Reinvestment Act ("ARRA"), ${ }^{6}$ enacted to "jump-start the economy to create and save jobs." $\mathrm{A}$ key part of this initiative is broadband as a means to stimulate economic activity and serve as the primary vehicle to realize the goals of ARRA. ${ }^{8}$ To this end, ARRA allocated over $\$ 7$ billion for broadband deployment to unserved areas of the United States. ${ }^{9}$ ARRA also called upon

3 See, e.g., IRONY OF REgUlatory REForm, supra note 1, at 92 ("In tandem with the railroads, the telegraph forged extra-local links among merchants, shippers, bankers, and brokers, and thus facilitated regional (as opposed to local) commerce."); SUSAN E. MCMASTER, THE TELECOMMUNICATIONS INDUSTRY 6-11 (Greenwood 2002) (discussing the emergence of the telephone as a preferred means of communications over the telegraph and providing an example of stockbrokers preferring to conduct business over the phone rather than via the slower telegraph).

4 Exec. Office of the President, The Recovery Act: Building a Platform for Private SECTOR INNOVATION: INVESTMENTS IN BRoAdBAND, SMART GRID, AND HEALTH INFORMATION TECHNOLOGY 27-30 (Aug. 2010), available at http://www.whitehouse.gov/sites/default/files/microsites/Recovery_Act.pdf.

5 For example, one study suggests that, absent new regulations that discourage investment in networks, broadband is expected to create or sustain 500,000 jobs through 2015 . See Robert W. Crandall \& Hal J. Singer, The Economic IMPaCt of Broadband InvestMENT 3 (Feb. 23, 2010), http://www.ncta.com/PublicationType/ExpertStudy/The-EconomicImpact-of-Broadband-Investment.apx. Conversely, the introduction of new regulations could deter capital expenditures in broadband networks, which could in turn result in the loss or failed creation of at least 500,000 jobs through 2015 and the loss of tens of billions of dollars in economic output. See Charles M. DAVIDSOn \& BRET T. SWANSON, AdVANCED COMMC'NS L. \& POL'y INST., Net NeUtrality, Investment \& Jobs: Assessing the PoTENTIAL IMPACTS OF THE FCC'S PROPOSED NET NEUTRALITY RulES ON THE BROADBAND ECOSYSTEM i-ii (2010), http://www.nyls.edu/user_files/1/3/4/30/83/Davidson \& Swanson NN Economic Impact Paper - FINAL.pdf [hereinafter NET NEUTRALITY, INVESTMENT \& JOBS].

6 American Recovery and Reinvestment Act of 2009, Pub. L. No. 111-5, 123 Stat. 115 (2009).

7 FAQs for Citizens, Recovery.gov, http://www.recovery.gov/FAQ/Pages/ForCitizens.aspx (last visited Jan. 1, 2011).

8 See 155 CONG. REC. H 1048 (daily ed. Feb. 9, 2009) (statement of Rep. Christensen); 155 CONG. REC. H1558 (daily ed. Feb, 13, 2009) (statement of Rep. Waxman); U.S. Gov'T ACCOUNTABILITY OfFICE, GAO-10-823, RECOVERY ACT: FuRTHER OPPORTUNITIES EXIST TO Strengthen OVERsight of BroadBand Stimulus Programs 30 (2010).

9 American Recovery and Reinvestment Act, Pub. L. No. 111-5, 123 Stat. 115, 118, 
the FCC to undertake an extensive review of the current broadband sector and issue a national plan to ensure the deployment and usage of broadband "technology ... intersects with just about every great challenge facing our nation." 10 The FCC's National Broadband Plan was issued in March 2010."

A close look at the ARRA legislation and other supporting legislative and regulatory initiatives seeking to bolster economic activity, however, reveals that, while wired broadband deployment (e.g., build-out of existing cable or fiber networks) is important, it is wireless broadband that is vital to realizing the myriad goals of policymakers at the state and federal levels. ${ }^{12}$ Indeed, as discussed in this article, wireless broadband will be indispensible to key gains in the public safety, healthcare, energy, and education arenas. ${ }^{13}$ The portability and flexibility inherent in wireless broadband facilitates a wider array of applications and uses than are possible via purely wired networks. For example,

$119,128,512-516(2009)$

10 In re A National Broadband Plan for Our Future, Notice of Inquiry, 24 F.C.C.R. 4342 भा 2, 6 (Apr. 8, 2009).

11 Press Release, Fed. Commc'ns Comm'n, FCC Sends National Broadband Plan to Congress (Mar. 16, 2010), available at http://hraunfoss.fcc.gov/edocs_public/attachmatch/DOC-296880A1.pdf. See generally FED. COMmC'Ns COMm'N, CONNeCting AMERica: The National Broadband Plan (2010), available at http://www.broadband.gov/download-plan [hereinafter NATIONAL BROADBAND PLAN].

12 See, e.g., Julius Genachowski, Chairman, Fed. Commc'ns Comm'n, Prepared Remarks at the International CTIA Wireless I.T. \& Entertainment: America's Mobile Broadband Future 2-3 (Oct. 7, 2009), available at http://hraunfoss.fcc.gov/edocs_public/attachmatch/DOC-293891Al.pdf (highlighting the "promise of mobile broadband") [hereinafter Genachowski Wireless Remarks-Oct. 7, 2009]; Julius Genachowski, Chairman, Fed. Commc'ns Comm'n, Prepared Remarks at the International Telecommunications Union Global Symposium for Regulators: ICT: Global Opportunities and Challenges 3-4 (Nov. 10, 2009), available at http://hraunfoss.fcc.gov/edocs_public/attachmatch/DOC-294594Al.pdf (commenting that the FCC believes that "broadband is the future of mobile, and also that mobile is a key part of the strategy for broadband"); Julius Genachowski, Chairman, Fed. Commc'ns Comm'n, Prepared Remarks at the New America Foundation: Mobile Broadband: A 21st Century Plan for U.S. Competitiveness, Innovation and Job Creation 2 (Feb. 24, 2010), available at http://hraunfoss.fcc.gov/edocs_public/attachmatch/DOC-296490Al.pdf ("No area of the broadband ecosystem holds more promise for transformational innovation than mobile.") [hereinafter Genachowski Remarks-Feb. 24, 2010]; NATIONAL BROADBAND Plan, supra note 11 at 9-10 (noting that a core goal of the NBP is to ensure that the "United States should lead the world in mobile innovation").

13 See, e.g., Julius Genachowski, Chairman, Fed. Commc'ns Comm'n, Prepared Remarks at the NAB Show 2010, 3 (Apr. 13, 2010), available at http://hraunfoss.fcc.gov/edocs_public/attachmatch/DOC-297469Al.pdf ("Mobile Internet access can be not only a powerful platform for substantial $21^{\text {st }}$ century job and business creation, but also a critical part of the solution to pressing national challenges like education, health care, energy, and public safety.") [hereinafter Genachowski Remarks-April 13, 2010]. 
while robust wired broadband networks are essential for backhaul content transport, wireless connections at network's edge enable cutting-edge telemedicine applications like real-time in-home monitoring of a patient's vital signs. ${ }^{14}$ Similarly, wireless sensors are being used to make the electric grid more intelligent by monitoring the transmission of energy and providing customers and service providers with real-time usage data. ${ }^{15}$ These are but a few examples of the growing role that wireless broadband is playing in efforts to spur economic growth and modernize antiquated industries.

Yet unlike wired broadband, wireless broadband development is dependent upon a scarce, finite public resource: spectrum. ${ }^{16}$ Indeed, it is this distinguishing characteristic that makes the wireless sector uniquely vulnerable to regulatory adjustments regarding the allocation of this critical element. ${ }^{17}$ To date, the wireless sector has flourished under a regulatory framework that makes spectrum available in a relatively efficient manner. ${ }^{18}$

This article argues that, in order to realize further economic and social gains that are enabled by wireless broadband, innovators must have consistent access to additional, unencumbered spectrum resources. As a result, policymakers must implement policies that make additional swaths of the airwaves available to those innovators that are willing to risk capital in developing and deploying advanced services via wireless broadband.

Part II provides an analysis of the current wireless marketplace and highlights the increasingly indispensible role that mobile technology is playing in everyday life. Consumers use their wireless devices to make calls, send emails, surf the Internet, and participate in an array of activities that were impossible only a few years ago. Part II also describes how wireless broadband is used to deploy cutting-edge services and applications in a variety of industries that, traditionally, have had little interaction with the wireless sector. Examples of new wireless services and applications in the public safety, telemedicine, education, and energy sectors are provided to demonstrate that wireless broadband is beginning to drive innovation across the entire economy. ${ }^{19}$ These and other

\footnotetext{
14 See discussion infra Part II.B.2.

15 See discussion infra Part II.B.3.

16 Fed. Commc'ns Comm'n, Strategic Plan: FY 2003 - FY 2008 14, http://www.fcc.gov/omd/strategicplan/strategicplan2003-2008.pdf; Office of the Press Sec'y, Exec. Office of the President, Fact Sheet: Doubling the Amount of Commercial Spectrum to Unleash the Innovative Potential of Wireless Broadband (Jun. 28, 2010), http://www.whitehouse.gov/the-press-office/fact-sheet-doubling-amount-commercialspectrum-unleash-innovative-potential-wireles.

17 See discussion infra Part III.

18 Id.

19 See discussion infra Part II.; NAT'L ECON. CoUnCIL, EXEC. OfFICE Of The President, Recovery act Investments In BroadBand: Leveraging Federal Dollars To Create
} 
examples represent the results, to date, of a relatively forward-looking and market-driven spectrum allocation regime at the FCC. This regime, which has historically been reactive to market dynamics and consumer demand, is essential to fostering a vibrant wireless sector.

Part III discusses the evolution of the FCC's spectrum allocation policy in order to highlight best practices for developing and implementing effective policies going forward. Historically, the FCC has responded to increased consumer demand for advanced wireless services by making additional spectrum available for auction. However, on a few occasions over the last several years, the FCC has strayed from this approach by, among other things, encumbering spectrum with conditions that sought to ensure specific policy outcomes. At this critical moment in the evolution of both the broadband and wireless markets, it is incumbent upon policymakers to adhere to a regulatory approach that is responsive to market conditions and conducive to the type of experimentation that has positioned wireless broadband to be a key enabler of lifeenhancing, and increasingly lifesaving, services and applications.

Part IV draws upon previously discussed best practices to articulate a set of recommendations to modify the spectrum allocation policy framework. As a first step, policymakers must acknowledge the looming gap between the spectrum resources that innovators need and the spectrum resources likely to be made available, and act swiftly to implement a policy framework that makes these necessary raw materials immediately available. A key tool will be creating and maintaining an inventory that catalogues current spectrum uses and identifies under- and un-used swaths of the airwaves. Understanding how the airwaves are being used is essential to determining whether and how to reallocate spectrum resources to innovators that need them most. Finally, Part IV discusses the importance of providing network owners with wide latitude to employ network management techniques that enable new business models to be deployed.

\section{Foundational Principles}

Policymakers have premised many assumptions about future economic growth on the wide availability of advanced broadband networks. ${ }^{20}$ Wireless

JOBS AND CONNECT AMERICA (2009), available at
http://www.whitehouse.gov/sites/default/files/20091217-recovery-act-investmentsbroadband.pdf.

$20 \quad I d$; Memorandum from the Exec. Office of the President, Office of the Press Secretary, Unleashing the Wireless Broadband Revolution, to Heads of Executive Departments and Agencies (Jun 28, 2010), axailable at http://www.gpoaccess.gov/presdocs/2010/DCPD201000556.pdf [hereinafter Unleashing the Wireless Broadband Revolution]. 
broadband will be a key enabler of many of these anticipated gains. The foundational principles underlying the policy framework outlined in this article provide policymakers with a sufficiently flexible and forward-looking approach to providing additional spectrum for further innovation and to overseeing the continued evolution of the wireless market. These principles include:

Consumer demand for mobile broadband services and devices-including advanced smartphones and netbooks - is increasing rapidly each year. Innovators across the wireless broadband value chain-from device manufacturers to content developers to service providers-continue to provide new tools and applications in order to satisfy a seemingly insatiable demand for these services.

Mobile broadband is driving innovation across the entire wireless ecosystem and increasingly being used to deliver new services in a wide array of industries, including the healthcare, energy, public safety and education sectors. Over the course of the last two decades, the wireless sector has evolved at a rapid pace. As a result, sweeping or monolithic policies that seek micromanage market dynamics are insufficiently rigid and burdensome for a sector that changes daily.

The wireless sector has thrived under a regulatory approach that has implemented policies in reaction to, and not in anticipation of, consumer demand and market dynamics.

Spectrum is the lifeblood of the wireless industry. Without readily available spectrum resources, innovators are unable to deploy next-generation networks. Thus, additional spectrum is needed to continue fueling innovation and competition across the entire sector.

The spectrum that underlies all wireless broadband networks is a unique, finite resource that must be carefully monitored to ensure a consistent user experience. As such, wireless service providers require wide latitude to manage their networks in order to prevent congestion, delays, and outages.

In light of a looming gap between the amount of spectrum needed to support continued growth and innovation in the wireless sector and the relatively paltry amount that is likely to be made available in the short-term, policymakers should implement policies that facilitate a more streamlined process for reallocating underused or unused spectrum and that bolster a more robust secondary market for trading existing spectrum assets. In the longer-term, policymakers should develop a sufficiently flexible regulatory framework that permits regulators to make additional spectrum resources available to innovators in a more predictable and consistent manner. 


\section{INNOVATION UNSTRUNG: CURRENT AND FUTURE USES OF WIRELESS BROADBAND}

The wireless marketplace has fundamentally changed over the last several years. ${ }^{21}$ Whereas the primary use of a cellphone was once restricted to calling, a growing number of consumers use advanced handsets-also known as smartphones-to send and receive text messages and email, surf the Internet, and enable a universe of add-on applications that allow users to participate in a seemingly endless range of activities. ${ }^{22}$ This section assesses the current marketplace and analyzes recent trends in investment, innovation, and usage. It concludes that competition in the wireless marketplace drives a significant amount of innovation and enables the deployment of widely available wireless broadband networks.

\section{A. A Mobile Society: An Overview of the Current Wireless Marketplace}

The United States is fast becoming a society defined by its level of productivity regardless of location. ${ }^{23}$ Indeed, the concept of mobility has begun to

21 See Gary E. Salazar, 25 Years: Generational Changes Highlight Evolution of Wireless Technology, RCRWIRELESS NEWS (Oct. 14, 2008, 6:00 AM), http://www.rcrwireless.com/article/20081014/WIRELESS/810139976/-1/25-yearsgenerational-changes-highlight-evolution-of-wireless (last visited Jan. 1, 2011).

22 For example, a recent Pew report noted a thirty-three percent increase from 2007 to 2009 in the percentage of adults who have used a mobile device to access the Internet. Over this same period of time, Pew observed a similar increase (thirty-two percent) in the percentage of users who have sent and received email via a wireless device. See JOHN HORRIGan, Pew Internet \& American Life Project, Wireless Internet Use 16, 23 (2009), http://www.pewinternet.org/ /media//Files/Reports/2009/Wireless-Internet-Use-WithTopline.pdf [hereinafter PEW WIRELESS STUDY 2009]. A 2010 study by Pew found that "[fifty-five percent] of American adults connect to the internet wirelessly, either through a Wi-Fi or WiMAX connection via their laptops or through their handheld device like a smart phone." See Lee Rainie, Pew InTERnet \& American Life Project, InTERnet, BroadBand, AND CELL PHONE STATISTICS 1 (2010), http://www.pewinternet.org/ /media//Files/Reports/2010/PIP_December09_update.pdf.

23 One study estimates that "by 2016 , the value of the combined mobile wireless voice and broadband productivity gains to the U.S. economy [is estimated to be] $\$ 427$ billion per year ...." See ROGER ENTNER, OVUM, THE INCREASINGLY IMPORTANT IMPACT OF WIRELESS Broadband TeChNOlOgy and SeRvices ON THE U.S. ECONOMY 2 (2008), available at http://files.ctia.org/pdf/Final_OvumEconomicImpact_Report_5_21_08.pdf. Another study has linked investment in wireless infrastructure with economic gains. It estimated:

[N]ew wireless broadband investments of $\$ 17.4$ billion will, within twenty-four months of making this additional investment, increase gross domestic product (GDP) by $0.9 \%$ to $1.3 \%$, which translates into dollar terms to $\$ 126.3$ billion to $\$ 184.1$ billion, and will result in an increase of between 4.5 million and 6.3 million jobs.

See Alan Pearce \& Michael S. Pagano, Accelerated Wireless Broadband Infrastructure Deployment: The Impact on GDP and Employment, 18 MEDIA L. \& POL'Y 105, 105-106 
inure itself into a growing segment of the population, ${ }^{24}$ driven by the wide availability of robust networks and a range of wireless devices, pricing plans and add-on services, all of which are changing the way Americans live and work. ${ }^{25}$ These trends have accelerated in recent years, due mostly to intense competition and innovation across the entire wireless ecosystem ${ }^{26}$ - wireless carriers are investing billions to create more expansive and robust networks; handset makers are designing more advanced devices to accommodate more intensive data usage; and content developers are using new platforms to deploy a universe of add-on applications, that are redefining the wireless market. ${ }^{27}$

There are currently over 292 million wireless subscribers in the United States, which represents a penetration rate of ninety-three percent ${ }^{28}$ The overall number of subscribers increased by fifty-one percent between June 2005 and June 2010 while the number of wireless-only households - those that "cut

(2009).

24 John Horrigan, Pew Internet \& Am. Life Project, Mobile Access to Data and INFORMATION http://www.pewinternet.org/ /media//Files/Reports/2008/PIP_Mobile.Data.Access.pdf.

25 For an overview of how the market has evolved to become more consumer-centric, see, e.g., Charles M. Davidson, Advanced Commc'ns L. \& Pol'y Inst., Losing the Forest For the TREes: Properly CONTEXTUALIZING THE USE OF EARLY TERMINATION FeES IN THE CURRENT WIRELESS MARKETPLACE 11 (2009), http://www.nyls.edu/user_files/1/3/4/30/83/Early Termination Fees - June 2009.pdf [hereinafter Losing the Forest]; TONY Clark \& Michael J. SANTORElli, AdVANCEd COMMC'NS L. \& Pol'y Inst., Federalism in Wireless Regulation: A New Model for a New WORLD $5-6$

(2009),

http://www.nyls.edu/user_files/1/3/4/30/83/Clark\%20\%20\&\%20Santorelli\%20-

$\% 20$ Wireless $\% 20$ Federalism $\% 20-\% 20$ February $\% 202009$.pdf.

26 The FCC has used the "ecosystem" concept to describe the "virtuous cycle" of interactions among "networks, devices, and applications." NATIONAL BROADBAND PlaN, supra note 11 , at 15 .

27 See U.S. Gov't AcCOUNTABILITy OfFice, GAO-10-779, Telecommunications: ENhaNCED DATA COLlection COUld Help FCC BeTter Monitor COMPETITION IN THE WIRELESS INDUSTRY 20 (2010); Phred Dvorak, RIM Tries Harder on Apps, Wall ST. J, Oct. 15, 2010, at B5; Jeffry Bartash, Wireless Carriers Pushing 'Smart' Strategy for Growth, MARKETWATCH (Dec. 10, 2009, 6:01 AM), http://www.marketwatch.com/story/wirelesscarriers-push-smart-strategy-for-growth-2009-12-10 (providing an overview of the wireless industry evolution away from voice-based services towards more data-intensive services and devices); Morgan Stanley, The Mobile InTERnEt RePORT 1 (2009), available at http://www.morganstanley.com/institutional/techresearch/pdfs/mobile_internet_report.pdf (observing " $[t]$ he mobile Internet is ramping faster than desktop Internet did . . . " and predicting "more users may connect to the Internet via mobile devices than desktop PCs within [five] years."); Jefferson Graham, App Developers Punp Up for iPad, USA TODAY, Mar. 24, 2010, at 1B (discussing the "huge market" created for applications developers when Apple released the iPad).

${ }_{28}$ See U.S. Wireless Quick Facts, CTIA - THE WIRELESS ASSOcIATION, $\mathrm{http} / / / \mathrm{www} . c t i a . o r g / a d v o c a c y /$ research/index.cfm/AID/10323 (last visited Jan. 1, 2011) [hereinafter CTIA Wireless Stats]. 
the cord" and relied exclusively on their cellphones for voice service-more than tripled..$^{29}$ Consumers use an average of over 700 minutes per month for calls, ${ }^{30}$ and a rapidly increasing number of subscribers use their handheld devices to participate in an array of non-voice activities, such as sending and receiving text messages (which remains the most widespread activity), ${ }^{31}$ searching online, ${ }^{32}$ purchasing goods and services via mobile phones, ${ }^{33}$ and sending and receiving emails, among many others. ${ }^{34}$ Indeed, these types of data-based, as opposed to voice-based, activities have dramatically increased in popularity over the last few years. ${ }^{35}$ As a result, data services and the revenues they gen-

29 Id. The Centers for Disease Control reported in May that nearly twenty-five percent of U.S. households were wireless-only by the end of 2009. STEPHEN J. BLUMBERG \& JULIAN V. LuKE, CTR. FOR DISEASE CONTROL, WIRELESS SUBSTITUTION: EARLy RElEASE OF EstiMATES FROM THE NATIONAL HEALTH INTERVIEW SURVEY: July-DECEMBER 20091 (2010), available at http://www.cdc.gov/nchs/data/nhis/earlyrelease/wireless201005.pdf.

30 For example, in 2007 , the average number of minutes used per month by subscribers was 769, up from 255 in 2000. In re Implementation of Section 6002(b) of the Omnibus Budget Reconciliation Act of 1993; Annual Report and Analysis of Competitive Market Conditions With Respect to Commercial Mobile Services, Thirteenth Report, 24 F.C.C.R 6185, 6277 at tbl.12 (Jan. 15, 2009) [hereinafter Thirteenth CMRS Report]. However, by June 2009 the average number of minutes used per month dropped to 735, reflecting a shift in utilization patterns by consumers towards more intensive data consumption. See In re Implementation of Section 6002(b) of the Omnibus Budget Reconciliation Act of 1993; Annual Report and Analysis of Competitive Market Conditions With Respect to Commercial Mobile Services, Fourteenth Report, 25 F.C.C.R. 11407, 11522 fig.21 (May 20, 2010) [hereinafter Fourteenth CMRS Report].

31 CTIA Wireless Stats, supra note 28 (reporting the average number of text messages sent per month in the U.S. was over 173 billion by mid-2010 and 1.81 trillion text messages were sent in the year ending June 2010).

32 Several recent high-profile acquisitions of mobile advertising firms by Google and Apple has underscored the enormous and as-yet untapped potential value of the mobile search market. See, e.g., Claire Cain Miller, Apple Buys Quattro, a Mobile Ad Company, N.Y. TIMES BITS BLOG (Jan. 5, 2010, 11:24 AM), http://bits.blogs.nytimes.com/2010/01/05/apple-is-said-to-buy-mobile-ad-company/.

33 Consumer acceptance of mobile transactions has grown significantly over the last two years and has fueled a market for mobile payments that is expected to reach $\$ 300$ billion per year by 2013. See Darcy Travlos, All Eyes on Mobile Commerce, Forbes.com (Nov. 10, 2009, 3:00 PM), http:/www.forbes.com/2009/11/10/travlos-apple-amazon-intelligentinvesting-mobile.html.

34 A December 2009 report by IDC found:

[T] ] most popular uses of the mobile Internet, currently, are visiting search engines, reading news and sports articles, downloading music and videos and sending and receiving e-mails and text messages. Over the next four years, however, IDC expects the fastest-growing applications of the mobile Web to include shopping, participating in online communities and blog creation....

See Michelle Maisto, Mobile Internet Users to Double by 2013, Says Report, EWEEK (Dec. 10, 2009), http://www.eweek.com/c/a/Mobile-and-Wireless/Mobile-Internet-Users-toDouble-By-2013-Says-Report-194522/.

35 In recognition of exponential growth in the popularity of wireless data services and 
erate have become a key component of business models for carriers. ${ }^{36}$ Between 2008 and 2009, the market for mobile data service grew thirty percent; it continues to expand despite recent economic turbulence. ${ }^{37}$ Cisco estimates rapid mobile data service growth over the next five years, driven in large part by greater demand for and use of video-based applications. ${ }^{38}$

\section{Network}

These new mobile uses are the result of three interrelated trends in the wireless sector. First, robust network infrastructure is becoming more available to support intense mobile data usage. With the cell phone market nearly saturated, network owners are investing more money to enhance the overall user experience, including customer service, network capacity, and reliability. ${ }^{39}$ To this end, wireless service providers invested over $\$ 21$ billion in their networks in the year ending June $2010^{40}$ and have averaged nearly $\$ 23$ billion per year in investments since $2001 .^{41}$ Such large-scale investments led to the deployment of third-generation ( $3 \mathrm{G}$ ) networks that facilitate data uses like Internet access

the revenues derived from these services, the FCC expanded its annual assessment of the wireless market to include "all mobile wireless services, such as voice, messaging, and broadband." In so doing, the FCC sought to highlight the "transformative importance of mobile wireless broadband, which has resulted in a shift from devices that can access the entire Internet." See Fourteenth CMRS Report, supra note 30; AARON SMITH, PEW INTERNET \& AMERICAN LIFE PROJECT, MOBILE ACCESS 12 (2010), http://www.pewinternet.com/ /media//Files/Reports/2010/PIP_Mobile_Access_2010.pdf.

36 See, e.g., NET NeUTRALITY, INVESTMENT \& JOBS, suprä note 5, at 21 (observing this shift and noting that additional key inputs - e.g., spectrum - will be needed to support longterm growth in the sector); see also Simon Flannery and Sean Ittel, Wireless Data: The Torch Passes from Voice to Data, at 4, Morgan Stanley Research, Telecom Services (June 1,2010 ) (predicting that "Wireless data revenue growth (excluding upside from emerging devices) should offset the decline in voice revenues").

37 See Jason Ankeny, U.S. Mobile Data Service Revenues Jump to $\$ 10.6 B$ in Q2, FIERCEMOBILECONTENT.COM (Aug. 10, 2009, 9:09 AM), http://www.fiercemobilecontent.com/story/u-s-mobile-data-service-revenues-jump-10-6bq2/2009-08-10.

38 See Cisco White Paper, Cisco Visual Networking Index: Global Mobile Data TRAFFIC FORECAST UPDATE 1 (2009), available at http://www.cisco.com/en/US/solutions/collateral/ns341/ns525/ns537/ns705/ns827/white_pa per_c11-520862.pdf (last visited Jan. 1, 2011) (estimating a global compound annual growth rate in mobile data traffic of 131 percent between 2008 and 2013) (hereinafter CISCO VISUAL NETWORKING INDEX].

39 See Fourteenth CMRS Report, supra note 30, at 168-170.

40 CTIA Wireless Stats, supra note 28.

41 See Ex Parte Letter from CTIA - The Wireless Association, to Chairman Julius Genachowski, Comm'r Michael J. Copps, \& Comm'r Robert M. McDowell, Fed. Commc'ns Comm (July 9, 2009), available at http://files.ctia.org/pdf/filings/2009_Wireless_Economic_Contributions.Letter.Final.pdf. 
and email. ${ }^{42}$ Adoption and usage of these advanced wireless services has increased substantially. ${ }^{43}$ Between 2008 and 2009, the number of $3 \mathrm{G}$ device owners grew by eleven percent. ${ }^{44}$ Recent FCC data on broadband availability reports that there are nearly 60 million wireless broadband connections in use across the United States. ${ }^{45}$ In addition, it is estimated that shipments of consumer electronic devices "embedded with mobile broadband connectivity" will have increased some fifty-five-fold between 2008 and 2014. ${ }^{46}$

New network deployment continues apace. Carriers are investing billions of dollars to bolster $3 \mathrm{G}$ availability and transition towards next-generation infrastructure that can support faster data transmission. ${ }^{47}$ The next iteration of wireless networks-the so-called fourth generation ("4G") - will be based on two different standards: WiMAX ${ }^{48}$ and long-term evolution ("LTE"). ${ }^{49}$

42 Initial 3G deployments began in the early 2000s. At about the same time, the FCC auctioned off 90 megahertz of "advanced wireless spectrum," which was allocated in a "flexible, market-oriented" way so that made carriers could easily aggregate swaths in this band, facilitating the deployment of nationwide networks. See In re Implementation of Section 6002(b) of the Omnibus Budget Reconciliation Act of 1993; Annual Report and Analysis of Competitive Market Conditions With Respect to Commercial Mobile Services, Eleventh Report, 21 F.C.C.R. 10947, 1T 73-74 (Sept. 26, 2006) [hereinafter Eleventh CMRS Report]. By 2008, the majority of the U.S. population lived in areas where $3 \mathrm{G}$ networks were available. Thirteenth CMRS Report, supra note 30, fit 141-147. For an overview of the types of services enabled by $3 \mathrm{G}$ networks, see Marguerite Reardon, $3 G$ Wireless Still Holds Promise, CNET News (Nov. 25, 2009, 4:00 AM), http://news.cnet.com/8301-30686_310404860-266.html (last visited Jan. 1, 2011); see also Scott Taves, 3G Phone Network Standards Vary by Carrier, MSNBC.COM (Sept. 3, 2008, 8:56:41 AM), http://www.msnbc.com/id/26511322.

43 Thirteenth CMRS Report, supra note 30, ๆๆ 204-206.

44 COMSCORE, The 2009 U.S. Digital Year IN REview: A Recap Of the Year IN DigfTAL MARKETING 12-13 (2010).

45 See Fed. Commc'ns Comm'n, Industry Analysis and Tech. Div., High-Speed SERVICES FOR INTERNET ACCESS: STATUS AS OF JUNE 30, 2008, tbl.1 (2009), http://hraunfoss.fcc.gov/edocs_public/attachmatch/DOC-292191A1.pdf.

46 See Michelle Maisto, Broadband-Enabled Devices to Grow 55-Fold by 2014, EWEEK (Jan. 4, 2010), http://www.eweek.com/c/a/Mobile-and-Wireless/BroadbandEnabledDevices-to-Grow-55-Fold-by-2014-210025/.

47 The FCC reports that, by 2009 , nearly 90 percent of the population was served by two or more mobile broadband providers. The FCC has also observed that all of the major wireless providers have detailed plans for $3 \mathrm{G}$ and $4 \mathrm{G}$ network deployments over the course of the next few years. Fourteenth CMRS Report, supra note 30, at 7-8.

48 See Rysavy RESEARCH, 3G AMERICAS HSPA to LTE-AdVANCED: 3GPP BROADBAND EVOLUTION TO IMT-ADVANCED (4G) 36-37 (2009) available at http://www.rysavy.com/Articles/2009_09_3G_Americas_RysavyResearch_HSPA-

LTE_Advanced.pdf [hereinafter BROADBAND EVOLUTION TO 4G]. WiMAX is a "family of interoperable technologies" adhering to the IEEE 802.16 standard that "has emerged as a potential alternative to cellular technology for wide-area wireless networks." Id. It was deployed on a small scale in 2009 by a consortium of companies led by Clearwire and Sprint, and extended in 2010. These companies plan to make WiMAX service available in eighty 


\section{Devices}

Second, the diversity of smartphones available and their increasing affordability drive data usage by increasing the number of consumers who utilize wireless services. A January 2010 survey found that, by the end of 2009 , fortytwo percent of consumers owned a smartphone. ${ }^{50}$ By 2011 , it is estimated that smartphone sales will overtake standard phone sales. ${ }^{\text {sl }}$ Some even predict that "by 2015 almost all shipped handsets will be smart." 52 This trend is significant since smartphone owners are much more likely to access the Internet on their handheld devices than those with traditional mobile handsets. ${ }^{53}$ According to the FCC, BlackBerry owners consume twice as much data per month than traditional handset owners, while iPhone owners consume eleven times as much data per month. ${ }^{54}$

Netbooks are also becoming a popular means of accessing the Internet wirelessly. These low-cost and lightweight laptop computers, designed primarily for web-browsing and email via a built-in wireless data cards (or air cards), have become enormously popular among business travelers and students alike. ${ }^{55}$ It is estimated that the number of netbooks sold in the United States in

markets by the end of 2010. See Marguerite Reardon, Clearwire to Bring WiMAX to 10 More Markets, CNET NEws (Aug. 3, 2009, 11:30AM), available at http://news.cnet.com/8301-1035_3-10301928-94.html.

49 LTE is an approach to spectrum management that allows for more efficient use of existing spectrum assets in order to provide faster and more reliable data speeds. See, e.g., ERICSSON, LTE: AN INTRODUCTION http://www.ericsson.com/res/thecompany/docs/whitepapers/tte_overview.pdf. LTE will be deployed by Verizon Wireless, AT\&T, and T-Mobile. These carriers are in different stages of upgrading their networks. See Marin Perez, T-Mobile Lays Out $3 G$ Plans, INFO. WEeK (Nov. 11, 2009, 3:22 http://www.informationweek.com/news/mobility/3G/showArticle.jhtml?articleID=2216013 38 (reporting that T-Mobile's 3G network will cover 200 million by the end of 2009; AT\&T's 3G upgrade will be complete in 2011; and Verizon Wireless continues to pursue its LTE upgrades).

so See Paul Carton \& Jean Crumrine, New Survey Shows Android OS Roiling the Smart Phone Market, CHANGEWAVE RESEARCH (Jan. 4, 2010), http://www.changewaveresearch.com/articles/2010/01/smart_phone_20100104.html.

51 See Presentation, Fed. Commc'ns Comm'n, Broadband Gaps 14 (Nov. 18, 2009) available at http://hraunfoss.fcc.gov/edocs_public/attachmatch/DOC-294708A1.pdf (citing TELECOMM. IndUSTRY Ass'N, ICT MARKET REVIEW \& ForeCAST (2009)) [hereinafter FCC Presentation].

52 See The Apparatgeist Calls, THE ECONOMIST, Jan. 2, 2010, at 56.

53 Thirteenth CMRS Report, supra note 30, at 192 (noting that fifty-eight percent of smartphone users had accessed information via their handheld device compared to just thirteen percent of all wireless subscribers).

${ }_{54}$ See Fourteenth CMRS Report, supra note 30, ๆ 182.

55 See Rik Myslewski, Apple Loses Students to Netbooks and Windows, THE REGISTER (UK)

(Aug.

19 ,

2009), 
2009 increased 137 percent from $2008 .{ }^{56}$ Given their popularity, portability and ability to access the Internet wirelessly, netbooks - and laptops-can, according to some estimates, at any given time consume nearly three-fourths of available network capacity despite comprising less than four percent of subscribers. ${ }^{57}$ Indeed, the FCC observes that owners of laptops/aircards consume 56 times as much data per month than traditional handset owners and six times as much data per month than iPhone owners. ${ }^{58}$

\section{Applications}

The third trend evident in the current wireless marketplace is a direct result of the first two: innovation at the network level has spurred innovation at the handset level, which has in turn spawned a new and vibrant market for add-on applications that leverage fast networks and advanced mobile devices to provide users with an array of services. ${ }^{59}$ Indeed, competition and innovation in each of these sectors has trickled down the value chain and empowered a new segment of innovators-software developers and other content providers-to contribute new inputs to the wireless marketplace. ${ }^{60}$

Perhaps the clearest example of this new segment is the marketplace for mobile applications that run on a growing number of smartphones. These applications are enabled by operating system (OS) software that allows users to download and install programs onto their phones. ${ }^{61}$ For example, the iPhone, iPad, and iPod Touch ${ }^{62}$ allow users to purchase and install any of the over three

http://www.theregister.co.uk/2009/08/19/apple_losing_out_to_netbooks/ (citing a study by DisplaySearch); see also Rafe Needleman, "Netbooks" Play Sidekick to Laptop, CBSNEWS.COM (Mar. 19, 2009), http://www.cbsnews.com/stories/2009/03/12/tech/real_technology/main4861664.shtml.

56 See Myslewski, supra note 55 (citing a study by DisplaySearch).

57 See Stacey Higginbotham, The Wireless Boom Will Cost the Carriers, BloomBERG BusINESS WEEK.COM (July 13, 2009, 7:05 PM), http://www.businessweek.com/technology/content/jul2009/tc20090710_158985.htm (last visited Jan. 1, 2011) (citing estimates made by Ericsson).

58 Fourteenth CMRS Report, supra note 30, $\uparrow 182$.

s9 Id. at Tा 299-338 (discussing the emergence of innovative and competitive "downstream" segments of the wireless market, including handsets and add-on applications).

60 The FCC defines the "value chain" in the wireless context as "the chain of individual, value-creating activities. This chain includes not only those activities performed by wireless communications service providers themselves, but also those performed by all other entities, including providers of inputs and complements to wireless communications services." See In re Fostering Innovation and Investment in the Wireless Communications Market, Notice of Inquiry, 24 F.C.C.R. 11322, 11323 n.2 (Aug. 27, 2009).

61 See, e.g., Fourteenth CMRS Report, supra note 30, 19 318-332 (discussing mobile applications).

62 Although not a cell phone, the iPad and iPod Touch are important mobile computing 
hundred thousand applications, many developed by third parties, that Apple, the device's developer, previously vetted and approved for use on the device. ${ }^{63}$ To date, over six billion applications have been downloaded via Apple's App Store for use on its mobile devices. ${ }^{64}$ The popularity of this service has spurred the development and incorporation of similar operating systems in a number of other phones. T-Mobile and Verizon Wireless, for example, have released myriad new phones that use the Android OS and that support applications made available in the Android Market. ${ }^{65}$ BlackBerry, an early leader in the smartphone market, has also launched its own application marketplace, App

devices that include all of the functionality of an iPhone expect for the ability to make and receive calls. Indeed, according to one recent analysis, "of the 58 million iPhone OS devices sold worldwide through September, the iPod Touch ... represents 40 percent of the market, with 24 million units sold." Andy Patrizio, iPod Touch Asserts Its Presence, INTERNETNEWS.COM (Dec. 7, 2009), http://www.internetnews.com/hardware/article.php/3851716/iPod+Touch+Asserts+Its+Pres ence.htm (citing an analysis by mobile analytics company Flurry). The iPad is able to run most of the apps available for the iPhone and iPod touch, and 11,000 additional apps have been created exclusively for the device. See Press Release, Apple, Apple Sells Three Million iPads in 80 Days (June 22, 2010), available at http://www.apple.com/pr/library/2010/06/22ipad.html.

63 See 148APPS.BIZ, App Store Metrics, http://148apps.biz/app-store-metrics/ (last updated Aug. 17, 2010). Apple's veto power over the content of applications for sale on iTunes has led to criticism, especially with regard to a perceived lack of clear and transparent criteria for rejecting applications. See Brian Chen, A Call for Transparency in Apple's App Store, WIRED.COM (Apr. 26, 2010, 8:00 AM), http://www.wired.com/gadgetlab/2010/04/app-store-transparency/.

64 See, e.g. MG Siegler, Apple Has Paid \$1 billion to App Developers (and Other Key Stats), TECH CRUNCH (June 7, 2010), available at http://techcrunch.com/2010/06/07/ipadibooks-app-store-stats/. The growth of Apple's App Store has been remarkable. The App Store was launched in July 2008 with "just 500 applications." Jim Dalrymple, Apple Reaches 100,000 Apps, 2 Billion Downloads, CNET News (Nov. 4, 2009, 7:51 AM), http://news.cnet.com/8301-13579_3-10390454-37.html. That number swelled to over 100,000 by November 2009 and 220,000 by June 2010 . The one billionth app downloaded from the store took place in April 2009, nine months after the store was launched. See Arik Hesseldahl, Almost a Billion iPhone Apps Downloaded, BusINESSWEEK.COM BYTE OF THE APPLE BLOG (Apr. http://www.businessweek.com/technology/ByteOfTheApple/blog/archives/2009/04/almost_ a billio.html. The two billionth download occurred in November 2009. See Brad Stone, Apple's App Store Tops 3 Billion Downloads, N.Y. Times Bits Blog (Jan 5, 2010, 1:08 PM), available at http://bits.blogs.nytimes.com/2010/01/05/apples-app-store-tops-3-billiondownloads/. In sum, it took about two years for six billion apps to be downloaded from the App Store. See Charles Cooper, Apple Revamps iPod Line, Upgrades iTunes, Apple TV, CBSNEws.COM (Sept. 1, 2010, 1:57 PM), http://www.cbsnews.com/8301-501465_16220015327-501465.html.

65 See Android Market, http://www.android.com/market/ (last visited Jan. 1, 2011). For an extensive list of information about current Android handset offerings, see ANDROPHONES.COM, http://www.androphones.com (last visited Jan. 1, 2011). 
World. ${ }^{66}$ Microsoft ${ }^{67}$ and Sprint, ${ }^{68}$ among others, have also launched online stores for wireless applications. Innovators are also developing add-on applications for use on a wider array of handsets. For example, one companyGetJar-offers "about 60,000 applications for nearly 2,000 different mobile phones." ${ }^{\prime 69}$ As a result of such vibrant and swift innovation, the market for addon apps is expected to grow nearly fourfold over the next several years, increasing from a $\$ 1$ billion a year business in 2009 to $\$ 4$ billion per year by $2012 .^{70}$

\section{Effects on Marketplace}

The immense success of the applications market has impacted the wireless market in two key ways. First, the applications market provides subscribers with access to a universe of new data services that are not available on other, less sophisticated phones. ${ }^{71}$ Smartphone users are thus much more dataintensive users. ${ }^{72}$ Second, and perhaps most important, this new business model has opened the wireless market to a new group of third-party innovators that would otherwise not have entered the wireless space. ${ }^{73}$ Traditionally, thirdparties were relegated to producing hardware add-ons for cell phones (e.g., head-sets) or coordinating software additions with mobile service providers. ${ }^{74}$

66 See BlackBerry App World, BLACKBERRY http://na.blackberry.com/eng/services/appworld/ (last visited Jan. 1, 2011).

67 See Sean Ludwig, Hands On with the Windows Mobile Marketplace, PC MAGAzINE (Oct. 8, 2009), http:/www.pcmag.com/article2/0,281 7,2354012,00.asp.

68 See Jason Ankeny, Sprint to Open Mobile App Store in 2010, FIERCEMoBILECoNTENT (Oct. 30, 2009, 9:23 AM), http://www.fiercemobilecontent.com/story/sprint-launchmobile-app-store-2010/2009-10-30.

69 See Jenna Wortham, Giving Your Phone More Oomph: Entrepreneurs Venture Beyond the iPhone with Apps for the Not-Quite-Smartphone Set, N.Y. TIMES, Jan. 4, 2010, at $\mathrm{B} 1$.

70 See Douglas MacMillan, Peter Burrows \& Spender E. Ante, Inside the App Economy, BLOOMBERG BUSINESS WEEK.COM (Oct. 22, 2009, 5:00 PM), http:/www.businessweek.com/magazine/content/09_44/b4153044881892.htm [hereinafter App Economy].

71 Cf. id. ("[S]martphones and other portable devices are transforming the tech world.")

72 See Nate Anderson, Wireless Carriers Beg FCC for Spectrum, Blame Smartphones, ARS TECHNICA (Sept. 27, 2009, 7:00 PM), http://arstechnica.com/techpolicy/news/2009/09/wireless-carriers-beg-fcc-for-spectrum-blame-smartphones.ars. For example, AT\&T has reported 5,000 percent growth in wireless data usage since the iPhone was released. Similarly, T-Mobile reported that users of its advanced smartphone, the Gl, use 50 times more data than the average T-Mobile subscriber. Id.

73 NET NEUTRALITY, INVESTMENT \& JOBS, supra note 5, at 14-15 (noting the app market represents another avenue for job creation in the broadband sector).

${ }_{74}$ See Jenna Wortham, Apple's Game Changer, Downloading Now, N.Y. TIMES, Dec. 6, 2009, available at http://www.nytimes.com/2009/12/06/technology/06apps.html (last visited 
This new openness on the part of carriers is fostering new modes of innovation across each segment of the market. ${ }^{75}$

The three trends described above have positioned the wireless market for further fundamental change. Indeed, the FCC has posited that "mobile broadband represents the convergence of the last two great disruptive technologiesInternet computing and mobile communications-and may be more transformative than either of those previous breakthroughs."76 As a result of the wide availability and usage of wireless broadband in the many ways discussed above, other sectors of the economy are rapidly incorporating wireless broadband into new products and business models. Indeed, as discussed in the next section, wireless broadband is driving innovation in a number of nontraditional contexts as non-communications companies seek to leverage ubiquitous networks and insatiable consumer demand for mobile services in order to further inure wireless into additional aspects of everyday life.

\section{B. Where Wireless Broadband is Taking Us: An Analysis of Four Sectors on the Cutting Edge}

Stakeholders in the public safety, telemedicine, energy, and education spaces are using wireless broadband to create new life-enhancing services for use in an array of contexts. Innovators in each space are leveraging the mobility and reliability inherent in wireless broadband networks to develop cuttingedge solutions to address a number of problems identified by policymakers.

\section{Public Safety}

Wireless connectivity has proven to be invaluable in recent public emergencies at both the local and national levels. ${ }^{77}$ In these instances, subscribers have relied on their cell phones and wireless data devices to contact emergency personnel and to communicate with family. ${ }^{78}$ The reliability and mobility inherent in wireless networks provides subscribers with a sense of personal protection

\footnotetext{
Jan. 1, 2011) (noting that "Gone are the days when mobile developers had to negotiate with major telecommunications companies if they had any hopes of publishing their applications on a mobile phone") [hereinafter Apple's Game Changer].

75 NET NEUTRALITY, INVESTMENT \& JOBS, supra note 5, at 15.

76 National Broadband Plan, supra note 11 , at 75.

77 See Wireless Communication Solutions for Emergency Situations, HoMELAND SECURITY NEwSWIRE, (Mar. 8, 2010) http:/homelandsecuritynewswire.com/wirelesscommunication-solutions-emergency-situations.

78 Lee Rainie \& Scott Keeter, Pew Internet \& Am. Life Project, Pew Internet Project DATA MEMO 9 (2006), available at http://www.pewinternet.org/ /media//Files/Reports/2006/PIP_Cell_phone_study.pdf.pdf.
} 
in dire situations. According to one recent study, a majority of mobile users cite their phone's availability in an emergency situation as one of its most important features. ${ }^{79}$ As a result, policymakers and other stakeholders are leveraging this level of consumer comfort with wireless services in order to provide more robust public safety applications, many of which are enabled by a wireless broadband connection.

Wireless broadband helps emergency services, such as police and fire departments, communicate and act more efficiently. Police departments, for example, use wireless devices to improve response time and bolster their effectiveness. ${ }^{80}$ Wireless computing devices in emergency vehicles allow technicians to load maps directing them to the location of an emergency call, receive real-time updates about criminal activities, access patient health records, and "beam images of a patient wirelessly from the road so that emergency room doctors can review them while the patient is in transit." ${ }^{\text {"11 }}$ Municipalities are also exploring the feasibility and value of deploying proprietary wireless networks to facilitate these public safety gains. ${ }^{82}$ New York City, for example, recently launched a next-generation wireless broadband network that supports high-speed data and video transmission for use by first responders. ${ }^{83}$

Policymakers are also using wireless technologies to provide real-time news updates and alerts during emergency situations. For example, the use of text

79 See Nicholas P. Sullivan, Cell Phones Provide Significant Economic Gains FOR LOW-INCOME AMERICAN HOUSEHOLDS 14-15 (2008), available at http://www.newmillenniumresearch.org/archive/Sullivan_Report_032608.pdf. Some discrete user groups view cell phones as especially indispensible in emergency situations. For example, more than three-quarters of people with disabilities reported their reliance on wireless devices in potential emergency situations, and seventy percent reported wireless devices provided a sense of security. These trends parallel general population patterns of wireless device reliance. See WIRELESS RERC, SECOND REPORT: FINDINGS OF THE SURVEY OF USER NEEDS (SUN) FOR WIRELESS TECHNOLOGY 2007-2009 5-6 (2009), http://www.wirelessrerc.org/publications/SUN Second Findings Report_2009-03-25.doc.

80 Motorola Wireless Broadband, Motorola Licensed $4.9 \mathrm{GHz}$ Wireless Broadband SOlutions FOR GOVERnMENT AND Public SAFETy (2009), http://ezine.motorola.com/government? $\mathrm{a}=346$ (follow "View PDF" hyperlink under "Motorola Licensed 4.9 GHz Wireless Broadband Solutions for Government and Public Safety Brochure").

81 Genachowski Remarks-Feb. 24, 2010, supra note 12, at 3.

82 According to MuniWireless.com, as of March 2009, 55 cities are deploying wireless public safety networks. See MUNIWIRELESS.COM, MUNIWIRELESS.COM 28 MARCH 2009 LiST OF US CITIES AND REGIONS 4 (2009), available at http://www.muniwireless.com/reports/Mar-28-2009-list-of-cities.pdf (last visited Jan. 1, 2011).

${ }_{83}$ See Gary E. Salazar, New York City Rolls Ahead with Public-Safety Network Plans, RCR WIRELESS (Jan. 21, 2009, 12:39 PM), http://www.rcrwireless.com/article/20090121/WIRELESS/901219992/new-york-city-rollsahead-with-public-safety-network-plans. 
messaging during and after recent tragedies like university shootings spurred the FCC and Congress to adopt a voluntary Commercial Mobile Alert System. ${ }^{84}$ This system allows providers to blast presidential alerts, threat alerts, and Amber alerts to those users who wish to receive such messages. ${ }^{85}$ In its National Broadband Plan, the FCC outlined a number of recommendations for using broadband to "enhance[e] the safety and security of the American people." ${ }^{86}$ Key among these proposals is the allocation of $10 \mathrm{MHz}$ to serve as the foundation for a "nationwide, interoperable public safety wireless broadband communications network." 87

Ubiquity of wireless broadband and the decreasing costs of wireless-enabled services are spurring innovation in a number of other public safety areas. More affordable wireless sensors are enabling engineers to monitor the safety of critical infrastructure like bridges. For example, in the wake of a major bridge collapse in Minnesota, a replacement bridge included wireless sensors that monitor a number of metrics in real-time, including corrosion levels and air temperature to trigger the automatic spraying of antifreeze on the roadway when temperatures fall below the threshold temperature set for the system. ${ }^{88}$ Application developers are also creating public safety-related services for use on smartphones. For example, one (controversial) application for the iPhone allows a user to identify the location of sexual offenders living in a given area. ${ }^{89}$

84 In re Commercial Mobile Alert System, First Report and Order, 23 F.C.C.R. 6144 ๆ 4-5. 26, 29 (Apr. 29, 2008).

85 See Chloe Albanesius, Emergency Alerts via Cell Phones Move Ahead, PC MAG. (Apr. 10, 2008), http://www.pcmag.com/article2/0,1759,2282812,00.asp.

86 NATIONAL BROADBAND PLAN, supra note 11 , at 313.

87 Id. at 313, 317. See Jon M. Peha ET Al., Fed. CommC'ns Comm'N, The Public SafeTy Nationwide Interoperable Broadband Network: A New Model for Capacity, PERFORMANCE AND COST 1 (2010), available at http:/hraunfoss.fcc.gov/edocs_public/attachmatch/DOC-298799A1.pdf (providing "a technical analysis of the capacity and performance of the public safety broadband network assuming that the National Broadband Plan recommendations concerning this network are implemented"). See infra, Part III.D for additional D-Block discussion.

88 See, e.g., Span of Control, THE ECONOMIST, Sept. 3, 2009, at 6 (noting that "[t]he cost of all this technology was around $\$ 1 \mathrm{~m}$, less than $1 \%$ of the $\$ 234 \mathrm{~m}$ it cost to build the bridge.").

89 See MG Siegler, The iPhone's Latest Hit App: A Sex Offender Locator, TECH CRUNCH (July 25, 2009), http://techcrunch.com/2009/07/25/the-iphones-latest-hit-app-asex-offender-locator/. Siegler notes that

The app allows you to see a list of offenders based on your current location (using the iPhone's location services), any contact's address, or it allows you to manually enter an address. The app then scours the database and lists the sexual offenders based on their proximity to the location you gave. You can click on any of these names to get a picture of the person, their information like date of birth, height, weight, and a picture. And you can also see the specific sexual crime they were charged with. Id. 
These and many other innovations are reliant on wireless broadband networks that support real-time data transmission. ${ }^{90}$

\section{Telemedicine \& Healthcare}

Broadband is playing an increasingly important role in healthcare by enabling a universe of telemedicine services that provide a number of lifeenhancing, and potentially lifesaving, benefits. ${ }^{91}$ Broadband-enabled telemedicine and health information technology (HIT) services provide quality medical care to rural parts of the country, streamline the administration of healthcare, and empower individuals to have more control over medical decisions. ${ }^{92}$

Wireless broadband in particular is of critical importance to the shift towards more individualized, in-home care of patients. ${ }^{93}$ For example, wireless broadband is a key component of in-home monitoring systems that track the movements and vital signs of patients in real-time in order to, among other things, prevent falls. ${ }^{94}$ These types of services are increasingly popular among seniors, people with disabilities and others, and could enable enormous costsavings. ${ }^{95}$ According to one study, "a full embrace of remote monitoring alone could reduce healthcare expenditures by a net of $\$ 197$ billion (in constant 2008 dollars) over the next [twenty-five] years with the adoption of policies that reduce barriers and accelerate the use of remote monitoring technologies."96 The

90 See, e.g., Advanced Wireless Broadband Technology Will Help Reduce Crime in El Salvador, RTI Int'l (June 3, 2010), http://www.rti.org/news.cfm?objectid=8D07A966-0111C4B2-59D8DEFAA03A0CD6.

91 National Broadband Plan, supra note 11, at 199. The FCC dedicated a chapter of its National Broadband Plan to examining how broadband impacts and enhances healthcare. Id. at 199-222.

92 See generally Charles M. Davidson \& Michael J. Santorelli, The Impact of Broadband on Telemedicine, A Report to the U.S. Chamber of Commerce (2009), available at http:/www.nyls.edu/user_files/1/3/4/30/83/BroadbandandTelemedicine.pdf [hereinafter BROADBAND \& TELEMEDICINE].

93 See Elizabeth G. Olson, The Virtual Doctor Visit, Wash. Post, Nov. 17, 2009, at E5 (describing a number of recent innovations that facilitate in-home care for senior citizens, some of which use wireless Internet connections to relay data between patient and doctor); Genachowski Remarks-Feb. 24, 2010, supra note 12, at 3 ("Mobile medicine takes remote monitoring to a new level. A patient's heart rhythm can be monitored continuously, regardless of her whereabouts, and diabetics can receive continuous, flexible insulin delivery through real-time glucose monitoring sensors that transmit date to wearable insulin pumps.").

94 See, e.g., Steve Lohr, Watch the Walk and Prevent a Fall, N.Y. TIMES, Nov. 8, 2009, at 4 (describing a pilot program that uses wireless sensors to track and prevent falls by senior citizens, which are fairly prevalent among the elderly and result in $\$ 75$ billion of healthcare and other costs each year).

95 Id

96 See Robert litan, Better Healthcare Together, Vital Signs via Broadband: 
market for such services is poised to become a multi- billion dollar per year industry, and, by 2012, it is estimated that 3.4 million seniors will be using networked sensor applications to monitor and improve their health. ${ }^{97}$

In-home monitoring via wireless broadband provides a number of benefits. First, wireless monitoring makes the administration of healthcare more efficient. A pilot initiative sponsored by the U.S. Veterans Association, for example, found that in-home chronic disease management tools (e.g., teleconsultations, remote diabetes monitoring) resulted in forty percent fewer emergency room visits and a sixty-three percent reduction in hospital admissions. ${ }^{98} \mathrm{Sec}-$ ond, real-time monitoring is of particular importance to older Americans, as regular data collection allows doctors and caretakers to track and diagnose the early onset of chronic diseases like Alzheimer's, for example. ${ }^{99}$ Treatment of chronic diseases in the elderly is extremely costly, ${ }^{100}$ yet estimates show that early "interventions that could delay the onset of Alzheimer's disease by as little as one year would reduce prevalence of the disease by 12 million fewer cases in 2050" and potentially provide dramatic cost savings for this disease alone. ${ }^{101}$ However, concerns regarding the reliability and affordability of these systems could create barriers to more robust adoption in the near term. ${ }^{102}$

Each of these broadband-enabled telemedicine services will generate data that can be aggregated in electronic health records (EHRs). ${ }^{103}$ EHRs allow

Remote Health Monitoring Transmit Savings, Enhances Lives 2 (2008), available at http://www.betterhealthcaretogether.org/Library/Documents/VITAL SIGNS via BROADBAND FINAL with FOREWORD and TITLE pp 10 22.pdf.

97 See Senior Citizens to See High Tech Sensors in Homes, on Bodies to Monitor Health, SENIOR JOURNAL.COM, (Dec. 6, 2007), http://www.seniorjournal.com/NEWS/Features/2007/7-12-06-SenCit2See.htm.

98 See Marlis Meyer et al., Virtually Healthy: Chronic Disease Management in the Home, 5 DisEASE MANAGEMENT, no. 2, June 2002, available at www l.va.gov/visn $8 / \mathrm{v} 8 /$ clinical/cccs/articles/virtually.doc.

99 See Yung Bok Kim \& Daeyoung Kim, Healthcare Service with Ubiquitous Sensor Networks for the Disabled and Elderly People, LeCTURE NOTES IN COMPUTING SCIENCES, Vol. 4061 (2006), http://www.springerlink.com/content/056710u827874021.

100 These diseases cost the United States more than $\$ 148$ billion annually in Medicaid and Medicare services and in indirect costs to businesses that employ [Alzheimer's] and dementia caregivers. See Alzheimer's Association, InTERnAtional Conference on ALZHEIMER'S DisEASE: HighlightS OF RESEARCH FINDINGS 2 (2008) available at http://www.alz.org/icad/documents/2008_ICADhighlights.pdf.

101 See Press Release, Johns Hopkins Univ. Bloomberg Sch. of Pub. Health, Alzheimer's Disease to Quadruple Worldwide by 2050 (June 10, 2007), available at http://www.jhsph.edu/publichealthnews/press_releases/2007/brookmeyer_alzheimers_2050. html.

102 See generally, BROADBAND \& TELEMEDICINE, supra note 92, at 36-46 (discussing an array of other potential barriers to more robust adoption of broadband-enabled telemedicine services).

103 NAtional BroadBand Plan, supra note 11, at 200-01. 
healthcare providers and patients to access a patient's full medical history via an Internet connection. ${ }^{104}$ In addition to providing patients with more power over individual health decisions, ${ }^{105}$ widespread implementation and use of EHRs can drastically reduce healthcare costs. ${ }^{106}$ One study estimates that costsavings could total $\$ 80$ billion each year. ${ }^{107}$ Mobile carriers and application developers are making available first-generation EHRs for use by subscribers on an array of mobile phones, ${ }^{108}$ and EHRs are a key component of healthcare reform. The stimulus legislation included some $\$ 19$ billion for the continued deployment and adoption of EHRs by providers across the country. ${ }^{109}$

Going forward, wireless broadband is poised to play an ever more critical role in healthcare. In the near-term, basic services like text messaging will continue to provide a primitive platform for the transmission of personal health data like blood sugar to a doctor for monitoring purposes. ${ }^{110}$ Hospitals and other healthcare providers are also increasingly using mobile phones to enhance communication ${ }^{\prime \prime \prime}$ and to make more informed decisions at the point of care. ${ }^{112}$ In the long-term, wireless telemedicine services are poised to become

104 See id. at 201-02.

105 See Richard Hillestad et al., Can Electronic Medical Record Systems Transform Helathcare? Potential Health Benfits, Savings, and Costs, in 24 HEALTH AFFaIRS 1103, 1107. 1109 (2005).

$106 \mathrm{Id}$.

107 See Richard Hillestad et al., Can Electronic Medical Record Systems Transform Healthcare? Potential Health Benefits, Savings, and Costs, 24 HEALTH AFFAIRS 1103 (2005).

108 For example, an application called Health Tracker allows users to store personal health information (e.g. weight, blood pressures, etc.) on their BlackBerry. See Production Information - Health Tracker for BlackBerry, T-MOBILE, https://tmobile.handango.com/home (follow "Blackberry" hyperlink: then follow "T-Mobile Blackberry Curve 8900" hyperlink; then follow "Health \& Fitness" hyperlink; then follow "Health Tracker for Blackberry" hyperlink) (last visited Jan. 1, 2011).

109 See Joseph Conn, Money to Boost EHR Initiatives Nationwide: Stimulus, ModerNHEALTHCARE.COM, (Feb. 23, 2009, 12:01 AM), available at http://www.modernhealthcare.com/article/20090223/REG/302239983 (last visited Jan. 1, 2011).

110 See Mark Terry, Text Messaging in Healthcare, 14 J. Telemedicine \& E-Health 520, 521 (2008).

111 See Mitch Wagner, Florida Hospitals Dial up iPhones for Nurses, INFo. WEEK, (Nov. 8, 2009), available at http://www.informationweek.com/news/healthcare/mobilewireless/showArticle.jhtml?articleID $=221600691$ (last visited Jan. 1, 2011) (reporting on a pilot program that used iPod touch devices to wirelessly relay text messages among nurses in lieu of traditional announcements, pages, and alarms. Patients reported better conditions due to a decrease in noise levels, and nurses reported an increase in the effectiveness of their care).

112 One article has observed:

The use of mobile information technology to assist healthcare professionals in making treatment decisions at the point of care is expected to improve the quality, safety, and 
seamlessly integrated into everyday life. For example, according to a recent report issued by OfCom, the British regulator of communications, wireless telemedicine applications will likely include services that can monitor personal information in real-time and automatically send emergency alerts when a person gets into an accident or suffers a sudden health event like a heart attack. ${ }^{113}$ The FCC has observed that "[w]ireless body sensor networks reduce infection risk and increase patient mobility by eliminating cables; they also improve caregiver effectiveness." vices and health-related add-on applications for smartphones, will depend on fast broadband connections to deliver real-time services that can save lives or detect the early onset of chronic diseases. ${ }^{115}$

\section{Energy \& The Smart Grid}

The electric power grid in the United States is tragically out-of-date. ${ }^{116}$ Increasing energy demand has put enormous strain on this antiquated infrastructure, leading to outages that have devastated small towns and, on occasion, large swaths of the country. ${ }^{117}$ Over the past forty years, five massive blackouts have occurred, three of which have taken place in the past nine years. ${ }^{118}$

Large-scale blackouts have enormous economic impacts. For example, the Northeast blackout of 2003 resulted in $\$ 6$ billion in economic losses in the re-

value of care delivery. Added value from these applications is extremely important for the growing number of seniors who want to independently age in place in the least restrictive environment possible."

See Gregory L. Alexander \& William R. Kehr, Mobile IT Applications, Long Term Living, Jan. 2009, at 20, 21.
113 OFCOM,
TOMORROW's
WIRELESS
WORLD
12
(2008),

http://www.stakeholders.ofcom.org.uk/binaries/research/technology-

research/randd0708.pdf; see also Adam Sherwin, New Wi-Fi Devices to Tell Doctors: Help!

I'm Having a Heart Attack, TimEs (London), May 7, 2008, at 4.

114 NATIONAL BROADBAND Plan, supra note 11, at 202.

$115 \mathrm{Id}$. at 206-207 (observing that "[s]martphones have become useful tools for many physicians managing patient care on the go" and providing "examples of the convergence between communications and medicine," including "[m]obile applications that help individuals manage their asthma, obesity or diabetes," a "[s]martphone application that displays real-time fetal heartbeat and maternal contraction data" and an "iPhone application that presents images for clinicians making appendicitis diagnoses.").

116 U.S. DEPT. OF ENERGY, THE SMART GRID: AN INTRODUCTION, 6-7, available at http://www.oe.energy.gov/DocumentsandMedia/DOE_SG_Book_Single_Pages(1).pdf [hereinafter DOE SMART GRIDS].

117 Id. at 6-7; see, e.g., Jaime Holguin, Biggest Blackout in U.S. History, CBS NEwS (Aug. 15, 2003), http://www.cbsnews.com/stories/2003/08/15/national/main568442.shtml.

118 DOE SMART GRIDS, supra note 116 , at 7. 
gion. ${ }^{119}$ A single blackout in Silicon Valley in the early 2000 s totaled $\$ 75$ million in losses. ${ }^{120}$ In 2000, a one-hour outage at the Chicago Board of Trade resulted in $\$ 20$ trillion in delayed trades. ${ }^{121}$ With energy demand continuing to outstrip energy transmission capacity growth, ${ }^{122}$ policymakers are examining a number of ways to upgrade the grid to increase energy efficiency. The $\mathrm{Na}$ tional Broadband Plan proposes integration of broadband technologies to modernize the grid and make it "smart." 123

A smart grid would provide energy companies and consumers with realtime usage and transmission data, ${ }^{124}$ allowing consumers to easily cut energy usage and utilities to better monitor their infrastructure and protect against blackouts. ${ }^{125}$ Wireless sensors placed at strategic points throughout the energy infrastructure use mobile broadband networks to relay supply and demand data across the many miles of transmission infrastructures. ${ }^{126}$ Currently, many utilities are experimenting with mobile networks to monitor transmission and usage, and some have begun to experiment with different spectrum bands to send and receive this data. ${ }^{127}$ The FCC is also exploring its role in facilitating the deployment of the smart grid via wireline and wireless broadband, ${ }^{128}$ and the Department of Energy, in a study regarding the communications requirements for the smart grid, has underscored the critical role that wireless networks will play in spurring deployment of advanced energy infrastructure. ${ }^{129}$

The smart grid will enable innovative solutions to spur energy efficiency.

119 Id. at 8.

$120 \mathrm{Id}$.

$121 \mathrm{Id}$.

122 The U.S. Department of Energy has found that demand for electricity in the United States has exceeded transmission growth by almost $25 \%$ each year since 1982 . DOE estimates that new and necessary electricity infrastructure to support great demand would require a $\$ 1.5$ trillion investment. Id. at 6,17 .

123 Chapter Twelve of the FCC's National Broadband Plan focuses on how broadband could be used to optimize the provision and consumption of energy. NATIONAL BROADBAND PLAN, supra note 11, at 263-80.

124 Id. at 272.

125 Id. at 269.

126 Katie Fehrenbacher, FAQ: Smart Grid, GlGAOM (Jan. 26, 2009, 9:00 PM), http://gigaom.com/cleantech/faq-smart-grid/; see NATIONAL BROADBAND PLAN, supra note 11 , at 269 .

127 See What if a WiMAX Gear Maker Tuned into Affordable UHF for You?, SMART GRID TODAY, (Sept. 11, 2009), http:/www.smartgridtoday.com/members/710.cfm (describing how a WiMAX equipment manufacturer retrofits its products to provide access to alternative wireless bands for use by energy utilities).

128 Nick Sinai, Clean-tech Investor Summit, BlogBand: THE OfFicial Blog of tHE NATIONAL BROADBAND PLAN (Jan. 21, 2010), http://blog.broadBand.gov/?entryId=111153.

129 See Communications Requirements of SMART GRID TECHNOlogies, U.S. DEPT. OF ENERGY (Oct. 2010) [hereinafter COMMUNICATIONS REQUIREMENTS OF SMART GRID TECHNOLOGIES]. 
For example, wireless smart meters will relay usage data from a customer's home to the grid for monitoring by the utility. ${ }^{130}$ Some wireless carriers, including T-Mobile, Verizon, and AT\&T, have partnered with smart meter companies to install data cards and other components to facilitate deployment. ${ }^{131}$ Eventually, smart grids and smart meters will communicate, likely via a wireless connection, ${ }^{132}$ with appliances and other items that consume energy in order to provide customers with a much more granular view of their energy footprint. $^{133}$

Many energy reform proposals focus on smart grid deployment as a method to realize cost savings and reduce carbon emissions. The U.S. Department of Energy estimates significant implementation of the smart grid could eliminate fuel and greenhouse gases equivalent to current emissions from 53 million cars. ${ }^{134}$ The smart grid also allows for diversification of the fuel supply through incorporation of intermittent renewable energy like wind power. ${ }^{135}$ The ARRA of 2009 appropriated billions of dollars for smart grid deployment to spur continued investment and innovation in wireless broadband for deployment of the smart grid. ${ }^{136}$

In sum, an array of mobile technologies - including wireless network infrastructure, sensors, and devices - will be critical to the timely deployment of a national smart grid. ${ }^{137}$

130 NATIONAL BROADBAND Plan, supra note 11, at 269.

131 See Ariel Schwartz, T-Mobile Joins the Smart-Grid Wireless Network Brigade, FAST COMPANY.COM, (April 23, 2009), http://www.fastcompany.com/blog/arielschwartz/sustainability/t-mobile-joins-smart-grid-wireless-network-brigade; AT\&T Finally Jumps into the Smart Grid Pool, SMARTSYNCH, (Mar 25, 2009), http://www.smartsynch.com/smartsynch_news_att.htm; Vodafone, Verizon Wireless and nPhase Announce Strategic Alliance to Provide Global M2M Solutions, Vodafone, (Feb. 15, 2010), http://enterprise.vodafone.com/insight_news/2010-02-15_vodafone_verizonwireless_nphase_announce_strategic_m2m_alliance.jsp.

132 See Building the Smart Grid, ECONOMIST TECH. Q., June 6, 2009, at 15-16; Campbell McCool, SmartSynch CEO Stephen Johnston: "Public Wireless Networks Will Drive the Smart Grid", SMARTSYNCH, (June 9, 2010), http://blog.smartsynch.com/smart-metertechnology/smartsynch-ceo-stephen-johnston-public-wireless-networks-will-drive-the-

smart-grid/.

133 See Building the Smart Grid, supra note 132, at 16.

134 DOE SMART GRIDS, supra note 116, at 3, 7, 17, 21.

135 See DOE SMART GRIDS, supra note 116 , at 9 .

136 See Katherine Ling, DOE Makes \$3OB Available to Jumpstart Renewable Energy, 'Smart Grid' Projects, N.Y. Times (July 30, 2009), http://www.nytimes.com/gwire/2009/07/30/30greenwire-doe-makes-30b-available-tojumpstart-renewable-16564.html.

137 For example, some have argued that Wi-Fi technologies, which operate at the edges of broadband networks, are well suited to address the three segments - home area network, neighborhood area network, and wide area network - of the smart grid. See WI-FI ALLIANCE, WI-Fi for the SMART GRID: Mature, INTEROPERABLE, SeCurity-ProteCted TeCH- 


\section{Education}

Wireless broadband technologies bring educational service to primary, secondary, continuing education, and "eager learners wherever they may be." 138 One of the important short-term uses of wireless broadband is for students in remote rural areas of the country, where wireless broadband will be a key enabler of distance learning services and Internet access, providing students with an opportunity to have similar resources as their urban and suburban counterparts. ${ }^{139}$ As the FCC has observed, broadband "can significantly improve the quality of education by providing students in rural America with the ability to do online research, interact with their teachers and schools from home, and obtain college credit and college degrees, even though they are not physically on campus." 140 Online learning via a wireless or wired broadband connection represents a new mode of learning that is a boon to all students. ${ }^{141}$

A recent pilot program in North Carolina, Project K-Nect, ${ }^{142}$ illustrates how wireless broadband can transform the educational experience and enhance individual achievement. The program used "smartphones with advanced mobile broadband technologies to deliver educational material to ninth-grade students." ${ }^{143}$ According to its project director, "[seventy-five] percent of partici-

NOLOGY FOR ADVANCED UTILITY MANAGEMENT COMMUNICATIONS 6-9 (2009), available at http://www.wi-fi.org/knowledge_center_overview.php?docid=4583. See also COMMUNICATIONS REQUIREMENTS OF SMART GRID TECHNOLOGIES, supra note 129, at 2, 11.

138 See Statement of Michael J. Copps, Comm'r, Fed. Commc'ns Comm'n, Fostering Innovation and Investment in the Wireless Communications Market (GN Docket No.09157); A National Broadband Plan For Our Future (GN Docket No. 09-51); Implementation of Section 6002(b) of the Omnibus Budget Reconciliation Act of 1993; Annual Report and Analysis of Competitive Market Conditions with Respect to Mobile Wireless Including Commercial Mobile Services (WT Docket No. 09-66); Consumer Information and Disclosure (CG Docket No. 09-158); Truth-in-Billing and Billing Format (CG Docket No. 98170); IP-Enabled Services (WC Docket No. 04-36) (Aug. 27, 2009) available at http://hraunfoss.fcc.gov/edocs_public/attachmatch/FCC-09-66A3.pdf. See generally NATIONAL BROADBAND Plan, supra note 11, ch. 11 at 241-62 (exploring how broadband can enhance education at all levels).

139 Bringing Broadband to Rural America: Report on a Rural Broadband Strategy, Public Notice, 24 F.C.C.R. 12791, I 19 (Oct. 19, 2009).

140 Id. 99.

141 A recent report by the U.S. Department of Education concluded that, "[o]n average, students in online learning conditions performed better than those receiving face-to-face instruction." Steve Lohr, Study Finds That Online Education Beats the Classroom, N.Y. TimES BITS BLOG, (Aug. 19, 2009, 1:08 PM), http://bits.blogs.nytimes.com/2009/08/19/study-finds-that-online-education-beats-theclassroom (citing U.S. Dept. OF Educ., Evaluation of Evidence-Based Practices in OnLINE LEARNING: A META-ANALYSIS AND REVIEW OF ONLINE LEARNING STUdies (2009)).

142 See Project K-Nect, http://www.projectknect.org/Project K-Nect/Home.html (last visited Jan. 1, 2011).

143 Carly Shuler, Joan Ganz Cooney Ctr. at Sesame Workshop, Pockets of Po- 
pating classes outperformed other cohorts in math subjects in the recently completed first phase of research. Students also displayed increases in average study time [and] significant gains in parental involvement."144

In addition to enhancing the in-classroom experience, wireless broadband provides access to an array of innovative services and applications available on devices (e.g., mobile handsets and netbooks) that can be used in the home. ${ }^{145}$ For example, students can supplement their learning by using smartphones to access supplemental materials such as podcasts, updated syllabi, reading materials, and discussion groups. ${ }^{146}$ Smartphones are indeed becoming a popular locus of innovation for an array of new add-on applications that enable students to access a wide array of tools and services targeted at enhancing educational performance. ${ }^{147}$ Digital textbooks are becoming increasingly available for wireless download on e-book readers like Amazon's Kindle and on handsets like the iPhone. ${ }^{148} \mathrm{~A}$ number of schools and states are shifting towards these more affordable and easily updatable versions of textbooks. ${ }^{149}$ Newer

tential: Using Mobile Technologies to Promote Children's Learning 14 (2009), http://joanganzcooneycenter.org/upload_kits/pockets_of_potential_1_.pdf.

144 See id.

145 The FCC's National Broadband Plan recommends opening a rulemaking proceeding to "fund wireless connectivity to portable learning devices" in an effort to ensure that all students are able to use the Internet outside of school. NATIONAL BROADBAND PLAN, supra note 11 , at 225-227.

146 See John Timmer, College Courses: Even "Offline" Classes are Online Now, ARS TECHNICA (Jan. 4, 2009, 5:00 PM), http://arstechnica.com/business/news/2009/01/trackingthe-evolution-of-online-education.ars.

147 See, e.g., Tim Devaney, Smartphones dial up learning experience, THE DETrorT NEws, Oct. 9, 2010, http://www.detnews.com/article/20101009/BIZ/10090310/1001/biz .

148 See, e.g., Daniel Etherington, Textbooks Now On iPhone, iPod Touch, THE APPLE BLOG (Aug. 10, 2009, 9:32 AM), http://theappleblog.com/2009/08/10/textbooks-now-oniphone-ipod-touch/; Declan Butler, The Textbook of the Future, NATURE, Apr. 2, 2009, at 568-70; Todd R. Weiss, College Textbooks Hit iPhone, iPod Touch, PCWOrLD (Aug. 12, 2009 , $11: 24$

AM), http://www.pcworld.com/article/170075/college_textbooks_hit_iphone_ipod_touch.html; Eric Engleman, CourseSmart Takes on Kindle, Puts Textbooks on iPhoñe, TeCHFLASH (Aug. $10, \quad 2009, \quad 9: 41 \quad$ AM), http://www.techflash.com/seattle/2009/08/CourseSmart_takes_on_Kindle_puts_textbooks_o n iPhone52896024.html.

${ }_{149}$ California, for example, recently announced that it has begun approving the use of digital textbooks in schools across the state. See John Timmer, Open Source, Digital Textbooks Coming to California Schools, ARs TECHNICA (June 9, 2009, 11:13 PM), http://arstechnica.com/tech-policy/news/2009/06/open-source-digital-textbooks-coming-tocalifornia-schools.ars. Proposed federal legislation would provide funding to schools for ereaders via the E-Rate program. See Press Release, Office of Rep. Ed Markey, Markey Introduces E-Rate 2.0 Bill to Bring Successful Program into $21^{\text {st }}$ Century (Feb. 9, 2010); see also Ron Schachter, Digital Classrooms Take Flight, District ADMIN., Oct. 2009, at 30-37; Michael Baumann, Bringing Digital Textbooks to the Masses, ECONTENT, Jan./Feb. 2010, at 
devices like the $\mathrm{iPad}$, with a $3 \mathrm{G}$ connectivity option for a fee and $\mathrm{Wi}-\mathrm{Fi}$, have spurred development of unique educational applications and tools currently unavailable on laptops or e-readers. ${ }^{150}$ Wireless-enabled services like these provide students, teachers, and parents with an array of innovative new approaches to learning.

\section{Takeaways}

Three important and interrelated ongoing trends in the wireless sector signal the critical role that wireless broadband services and the networks that support them will continue to play in all aspects of the economy. Market saturation and increasing consumer demand for additional and more robust mobile data services have spurred innovation and increased investment in networks, and have made service providers much more attentive and responsive to shifts in consumer preferences. ${ }^{151}$ As a result, wireless carriers are investing billions of dollars to bolster and extend existing networks and to deploy next-generation networks that can support more robust data uses. Second, innovation at the network level has spurred innovation at the handset level. Smartphones are increasingly prevalent and a new market for add-on software (e.g., applications and services) is thriving as consumers seek to increase mobility, productivity, and quality of life. Moreover, increased smartphone ownership and usage of add-on applications is further inuring a sense of mobility among a growing portion of consumers. Untethering from a wired broadband connection allows users to be more productive and reap a number of individual benefits that, in the aggregate, have important and discernible impacts on the economy. Third, these new usage patterns spur other sectors to leverage wireless ubiquity and insatiable demand for wireless services in order to provide new services to

\section{$12-13$}

150 See, e.g., Dennis Carter, Developers Seek to Link iPad with Education, ESCHOOL NEws (Apr. 5, 2010), http://www.eschoolnews.com/2010/04/05/ipad-app-store-has-wideselection-of-education-options/; see also iPad Features, APPLE, INC., $\mathrm{http}: / / \mathrm{www}$. apple.com/ipad/features (last visited Jan. 1, 2011) (explaining exclusivity of apps available for $\mathrm{iPad})$.

151 LOSING THE FOREST, supra note 25 (observing that, as a result of carriers competing to retain existing customers and poach customers from competitors, service providers are competing on array of terms other than price, including the number and type of service plans and handsets available to customers, the range of advanced services available and able to be amply supported by a given network, and customer service, among many others). A November 2009 study by the Government Accountability Office (GAO) found that the vast majority - eighty-four percent - of wireless customers were satisfied with their wireless phone service. U.S. Gov'T ACCOUNTABILITY OfFICE, GAO-10-34, FCC NEEDS TO IMPROVE $\begin{array}{llllll}\text { OVERSIGHT OF WIRELESS PHONE SERVICE } & 8 & \text { (2009), }\end{array}$ http://www.gao.gov/new.items/d1034.pdf. 
consumers. As detailed above, innovations in the public safety, healthcare, energy, and education sectors are providing consumers with heretofore unseen opportunities and services. These types of innovative business models are poised to spill over into a wider array of sectors across the economy. Private investment will drive innovation across these sectors and provide consumers with access to a nearly limitless universe of new services and applications, all of which will be available via wireless broadband on advanced handsets.

These three trends interrelate because they each rely on the availability of robust, next-generation mobile networks to enable new handsets, new applications, and new services. These networks are comprised of multiple components, including physical infrastructure (e.g., cell phone towers) and a more intangible resource that is essential for bolstering existing networks and deploying new ones: spectrum. Indeed, spectrum is the most important component of a wireless network. In order to ensure that these trends continue to evolve and multiply, it is essential that innovators have access to additional swaths of the airwaves. Thus, policymakers must immediately implement a forward-looking allocation strategy that makes additional spectrum available in a timely manner in order to support continued innovation across the wireless ecosystem.

\section{PAST AS PROLOGUE? DERIVING BEST PRACTICES FROM THE EVOLUTION OF FCC SPECTRUM ALLOCATION POLICY}

The present success of the wireless industry has been largely fostered by the FCC's careful approach to crafting policies and regulations that seek to guide rather than control the marketplace. The evolution of FCC spectrum allocation policy over the last three decades has largely paralleled an explosion in consumer demand for ever more innovative wireless devices and services, and has been largely successful in making spectrum available to innovators in a timely and efficient manner. In most instances, the FCC has forged policies reflective of the market rather than pursue anticipatory policies to predict consumer demand or technological innovation. ${ }^{152}$ This cautious yet forward-looking approach has spurred competition, fostered innovation, and provided consumers

152 Some have argued, though, that the FCC has not been aggressive enough in its approach to wireless spectrum allocation. For example, cellular technology was conceived in the 1940's but it was not until the early 1980's that the FCC was satisfied that the technology would benefit consumers and began licensing for its use. It is estimated that this delay cost the U.S. economy about $\$ 86$ billion (measured in 1990 dollars). See JEFFERY H. ROLPHS Et Al., Nat'l. Econ. Research Assocs.,Estimate Of loss To The United States Caused By THe FCC'S DELAY In LiCENSING Cellular Communications 1 (1991). 
with many welfare gains. ${ }^{153}$ The evolution of FCC spectrum allocation policy highlights best practices for policymakers as they develop policies for the wireless broadband future.

\section{A. Growing Pains: The FCC's Early Approach to Spectrum Allocation (1984- 1992)}

Once it deemed wireless telephony a viable technology that would likely appeal to consumers, ${ }^{154}$ the FCC initially took a very heavy-handed and deliberate approach to spectrum allocation ${ }^{155}$ in order to protect other spectrumdependent technologies from harmful interference (e.g., radio and television) and to foster the newborn market. ${ }^{156}$ Through its band plan, which outlined the accepted uses of a particular portion of spectrum, the FCC decided which services could be offered over which frequencies and how many licensees would be able to offer those services. ${ }^{157}$ Because of the strict limitations placed on the licensee and the marketplace, this approach to spectrum allocation was termed "command and control." 158 Major justifications for the command and control

153 Philip J. Weister \& Dale Hatfield, Spectrum Policy and The Next Frontier of Property Rights, 15 GEO. MASON L. REV. 549, 564 (2008) [hereinafter Next Frontier of Property Rights].

154 The FCC issued an NPRM and NOI in the late 1960s seeking comment on the reallocation of spectrum, some of which would be dedicated to "land mobile radio service." See, e.g., 47 C.F.R. $\$ 2.102$ (1968). In 1977, the FCC considered an application "to construct and operate the first developmental Mobile Radio Telecommunications system using Cellular concepts." The FCC was enthusiastic about this petition, specifically, and more generally about the promise of wireless telephony as a way to "achieve [its] objective of a nationwide, high capacity radiotelephone service." IIl. Bell Tel. Co., 63 F.C.C. 2d 655, 657 (1977).

155 See Next Frontier of Property Rights, supra note 153, at 558-59 (2008) ("The traditional command-and-control model of spectrum management operates based on the wise man theory of regulation .... [T]his approach generally presumes that regulatory decisions, and not market forces, are capable of deciding what uses of spectrum are best for the public.") (internal quotation marks omitted).

156 See id.

In essence, the FCC's early concern about interference in the radio spectrum was that, without close government supervision, everyone would use the identical frequency at the same time in the same place and no one would be heard as a result. Based on this fear, the FCC viewed interference like a virus to be avoided-as opposed to a fact of Id.

life (like different sources of light) that can be managed (say, by wearing sunglasses).

157 See Stuart Minor Benjamin Et Al., Telecommunications Law and Policy 67 (2nd ed. 2006) [hereinafter TELECOMM. LAW \& POLICY].

158 Id. From the beginning, critics of the "command and control" approach submitted that even though spectrum was a scare resource, it did not necessitate government control because free-market mechanisms could self-regulate and produce efficient outcomes. Ronald H. Coase first made this argument in the 1950s regarding licenses for television and radio. See Ronald H. Coase, The Federal Communications Commission, 2 J. L. \& EcoN. 1, 17-18 
policy included scarcity of spectrum and the potential for harmful interference. ${ }^{159}$ Because of the technological limitations of the first cellular networks, multiple users could not simultaneously use a portion of spectrum without interfering with other services. ${ }^{160}$

Even though wireless telephony service quality was unreliable and initially expensive, wireless carriers acquired a healthy number of new consumers each year. Between 1984 and 1985, the number of wireless consumers nearly tripled, increasing from 91,600 to 340,213 ; over the following year, that number doubled. ${ }^{161}$ Recognizing the inherent flaws of the command and control approach and the limitations it placed on the market in light of growing demand, the FCC began to implement more flexible spectrum use policies. ${ }^{162}$ For example, in 1988 the FCC allowed wireless license holders to employ a wider range of technologies when deploying cellular networks, a move intended to further spur growth in the cellular market and led to the development of new digital transmission technologies. ${ }^{163}$

By the 1990s, cell phones became more than just a novelty as consumer demand for wireless services increased significantly. At the end of 1990, over 5

(1959).

159 The Supreme Court first recognized the scarcity rationale to justify government control over spectrum in the context of broadcasting. NBC v. US, 319 U.S. 190, 213 (1943) ("[There are] certain basic facts about radio as a means of communication - its facilities are limited, they are not available to all who may wish to use them...[r]egulation of radio was therefore as vital to its development as traffic control was to the development of the automobile."); see also TELECOMM. LAW \& POLICY, supra note 157, at 30-37; Introduction to Cellular Communications, http://www.gsmfavorites.com/documents/introduction/gsm/ (last visited Jan. 1, 2011).

160 The Supreme Court first recognized the scarcity rationale to justify government control over spectrum in the context of broadcasting. NBC v. US, 319 U.S. 190, 213 (1943) (stating that "[there are] certain basic facts about radio as a means of communication - its facilities are limited, they are not available to all who may wish to use them...[r]egulation of radio was therefore as vital to its development as traffic control was to the development of the automobile."); see also TELECOMM. LAW \& POLICY , supra note 157 at $30-37$.

161 Eleventh CMRS Report, supra note 42, at 996 tbl. 1.

162 The FCC later admitted that when it was first forging policies for the wireless market, "no one predicted that the service would be as popular" as it quickly became. See In re Implementation of Section 6002(B) of the Omnibus Budget Reconciliation Act of 1993, First Report, 10 F.C.C.R. 8844, ๆ 3 (July 28, 1995) [hereinafter First CMRS Report].

163 See Thomas Hazlett, Wireless Craze, The Unlimited Bandwidth Myth, The Spectrum Auction Faux Pas, and the Punchline to Ronald Coase's "Big Joke": An Essay on Airwave Allocation Policy, 14 HARV. J. OF LAW \& TECH. 335, 485-86 (2001) ("Only in 1988, after licensees had built their big-city systems (where capacity was stretched) did the FCC allow digital telephones, in one of the great blunders in the history of telecommunications.") [hereinafter Wireless Craze]; see also In re Amendment of Parts 2 and 22 of the Commission's Rules to Permit Liberalization of Technology and Auxiliary Service Offerings in the Domestic Public Cellular Radio Telecommunications Service, Report and Order, 33 F.C.C.R. 7033, 19 1-2 (Oct. 13, 1988). 
million consumers subscribed to wireless services; by the turn of the century, this number approached 100 million. ${ }^{164}$ As a result of the explosion in consumer demand, Congress and the FCC sought to bolster competition by auctioning off roughly $140 \mathrm{MHz}$ of spectrum for "personal communications services" (PCS) in local and regional blocks. ${ }^{165}$ In addition, the FCC adopted a more flexible spectrum use approach by allowing PCS licensees to employ "any mobile communications service," not just the analog technology. ${ }^{166}$ This policy change spurred competition within the market and fostered creative approaches. For example, Nextel created a competitive network comprised of spectrum originally limited to specialized mobile radio (SMR) licenses and intended only for use as a private dispatch service. ${ }^{167}$ Through various FCC waivers, Nextel was able to transform the SMR spectrum into a competitive wireless network that did not require new policymaking by the FCC. ${ }^{168}$

The FCC's more flexible spectrum policies provided license holders latitude to experiment with using their portion of the airwaves rather than confining them to limited uses under the command and control approach. ${ }^{169}$ This created incentives for carriers to make more efficient and highly-valued choices in spectrum use. ${ }^{170}$ It was during this period that the FCC set a precedent by adjusting its policies vis-à-vis spectrum in reaction to market forces. ${ }^{171}$ This trend would continue well into the next decade as the wireless market evolved and matured.

\section{B. Growth Spurt: FCC Spectrum Allocation Policy during the First Wireless Boom (1993-2001)}

Between 1990 and 1993 the wireless market added an average of three million new subscribers per year, which represented an average annual growth of

\footnotetext{
164 Eleventh CMRS Report, supra note 42.

165 Wireless Craze, supra note 163, at 513-14.

166 TElECOMM. LAW \& POLICY, supra note 157, at 77.

167 See Jonathan E. Nuechterlein \& Philip J. Weiser, Digital Crossroads: AmeriCAN TElecommunications Policy in the InTERnet Age 244 (MIT Press 2005).

168 See id.

169 Cf. id. at 244-45 (discussing the evolution of FCC towards a "market-based model," in particular the "allocation of several bands to 'personal communications service' (PCS) licenses, which the holder [could] use to provide any mobile communications service, as well as fixed services, if provided in combination with mobile ones (but not broadcasting services under any circumstances).") (internal quotation marks omitted).

170 SPECTRUM POlicy TASK FORCE, FCC REPORT OF The SPECTRUM EfFiciency WorkING GROUP 16 (Nov. 15, 2002), available at http://www.fcc.gov/sptf/files/SEWGFinalReport_1.pdf [hereinafter SPTF REPORT].

171 NUECHTERLEIN \& WEISER, supra note 167 , at 244-45.
} 
about forty-four percent. ${ }^{172}$ By 1993 , there were sixteen million wireless subscribers in the United States. ${ }^{173}$ In order to accommodate this robust growth and ensure that the market would continue to expand, Congress in 1993 amended the 1934 Communications Act in the Omnibus Budget Reconciliation Act of 1993 (1993 Act) to create a national deregulatory framework for wireless services. ${ }^{174}$ The core provisions of the 1993 Act acknowledged the interstate nature of wireless, ${ }^{175}$ which required a more streamlined approach to unburden the market of many inconsistent state-level regulations. ${ }^{176}$

With regard to spectrum, the FCC, in 1994, implemented a radical new allocation strategy: auctioning off portions of the airwaves instead of just giving them away. ${ }^{17}$ The first ten licenses, earmarked for nationwide advanced paging services, were sold at auction for a total of $\$ 617$ million. ${ }^{178}$ Less than a year later, spectrum for personal communications services, which would form the first digital wireless networks, was auctioned off for a then-record of $\$ 7$ billion. ${ }^{179}$ The goals of the auction approach were to "promote efficient and intensive use of the electromagnetic spectrum; promote rapid deployment of new technologies; promote economic opportunity and competition by dissemination of licenses to a wide variety of applicants; [and] recover for the public a portion of the value of the public spectrum resource." ${ }^{180}$ Indeed, ahead of the very first spectrum auction in 1994, then-FCC Chairman Reed Hundt proclaimed that the auctions would "offer Americans the opportunity to purchase a piece

172 Eleventh CMRS Report, supra note 42.

173 Id.

174 Omnibus Budget Reconciliation Act of 1993, Pub. L. No. 103-66, § 6002(b), 107 Stat. 312,392 (codified in relevant part at 47 U.S.C. $\$ 332(2006)$ ). For an analysis of section 332, see Leonard J. Kennedy \& Heather A. Purcell, Section 332 of the Communications Act of 1934: A Federal Regulatory Framework That Is "Hog Tight, Horse High, and Bull Strong," 50 FED. COMM. L.J. 550 (1998) (analyzing section 332 as freeing wireless carriers "from the dual (federal and state) regulatory jurisdictional system designed to regulate the monopoly" wireline industry).

175 See Omnibus Budget Reconciliation Act of 1993, Pub. L. No. 103-66, § 6002(b), 107 Stat. 312, 392 (codified in relevant part at 47 U.S.C. $\$ 332(2006)$ ).

176 See Leonard J. Kennedy \& Heather A. Purcell, Wandering Along the Road to Competition and Convergence - The Changing CMRS Roadmap, 56 FED. COMM. L.J. 489, 498-99 (2004).

177 Omnibus Budget Reconciliation Act of 1993, Pub. L. No 103-66, Sect. 6002, 107 Stat. 312, 379086 (codified as 47 U.S.C. 309 (j) (2000)).

178 See Edmund L. Andrews, Airwaves Auctions Brings in $\$ 833$ Million for U.S. Treasury, N.Y. TiMES, July 30, 1994, at 1.

179 See Edmund L. Andrews, Winners of Wireless Auction to Pay $\$ 7$ Billion, N.Y. TIMES, Mar. 14, 1995, at D1.

180 R. Preston McAfee et AL., The Greatest Auction in History, in BetTer Living Through ECONOMICS 168, 170 (J. Sigfreid, ed., 2008). For an insightful analysis of how these initial auctions were designed to meet their Congressional mandate, see id. at 168-83. 
of the airwaves and then they - and their customers-will decide how to use it. The government is not deciding what is to be done with those airwaves-it is deciding to open that opportunity to everyone." 181 The "skylight," as Hundt put it, had truly been opened and a new age of wireless innovation began in earnest. ${ }^{182}$

Between 1993 and 1996, the number of wireless subscribers increased from just over sixteen million to forty-four million. ${ }^{183}$ At the time, price was considered a primary indicator of whether the wireless market was competitive. ${ }^{184}$ From 1993 to 1996 , the average monthly bill dropped from $\$ 61.48$ to $\$ 47.70$; between 1988 and 1996, prices halved, decreasing from $\$ 98$ to around $\$ 47$ per month. ${ }^{185}$ Similarly, the number of wireless carriers increased due to the availability of additional spectrum. ${ }^{186}$ This new dynamic pressured all carriers to invest heavily in their networks in order to ensure a minimum level of service quality, which quickly became another key indicator of competition. ${ }^{187}$ Consequently, the number of cell sites nationwide increased 134 percent, and the number of employees of carriers rose by roughly 110 percent during the 19931996 period. $^{188}$

As a result of these market forces, policymakers did not radically alter spectrum allocation policy in the 1990 s. For example, not even the massive regulatory overhaul of the telecommunications market in the middle of the decadewhich culminated in the landmark 1996 Telecommunications Act-impacted FCC spectrum allocation policy. ${ }^{189}$

The ready availability of robust spectrum resources, an increase in consumer demand, and the emergence of viable competitors in the marketplace drove

\footnotetext{
181 See Reed Hundt, Chairman, Fed. Commc'ns Comm'n, FCC Nationwide Narrowband PCS Auctions (July 25, 1994), available at http://www.fcc.gov/Speeches/Hundt/spreh421.txt.

$182 \mathrm{Id}$.

183 Eleventh CMRS Report, supra note 42, at 11033 tbl.1.

184 First CMRS Report, supra note 162, at 70.

185 Eleventh CMRS Report, supra note 42, at 11033 tbl.1.

186 See In re Implementation of Section 6002(b) of the Omnibus Budget Reconciliation Act of 1993; Annual Report and Analysis of Competitive Market Conditions With Respect to Commercial Mobile Services, Third Report, 13 F.C.C.R. 19746, 19751 (May 14, 1998) [hereinafter Third CMRS Report].

187 William R. Drexel, Telecom Public Policy Schizophrenia: Schumpeterian Destruction Versus Managed Competition, 9 VA. J. L. \& TECH. 5, 45-47 (2004).

188 Eleventh CMRS Report, supra note 42, at 11033 tbl. 1.

189 See, e.g., Wireless Craze, supra note 163, at 359; James Speta, Deregulating Telecommunications in Internet Time, 61 WASH. \& LEE. L.R. 1063, 1111 (2004); see Reed Hundt, Ten Year $s$ Under the 1996 Telecommunications Act, 58 FED. COMM. L.J. 399, 401 (2006); see In re Federal-State Board on Universal Service, Report \& Order, 12 F.C.C.R.

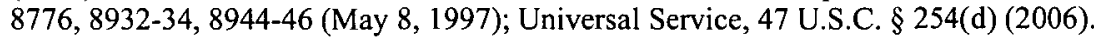


innovation in the late 1990s. Technological convergence, a hallmark of the wireless industry throughout its history, began in earnest in the late 1990s. ${ }^{190}$ In 1997, for example, a new service offering - mobile data - was first observed by the FCC, ${ }^{191}$ along with a rise in the use of digital technologies to increase network capacity. ${ }^{192}$ By the end of the century, the wireless market had fully blossomed. Subscribership surpassed 100 million in $2000,{ }^{193}$ networks were more national in nature, ${ }^{194}$ and mobile data was a much more integral part of wireless service. ${ }^{195}$ Indeed by 2000-2001, many wireless carriers announced plans to develop and deploy $3 G$ networks to provide consumers with better mobile data services like Internet access and email. ${ }^{196}$

By the dawn of the twenty-first century, the wireless market was developing more quickly than ever. ${ }^{197}$ The number of minutes used per month by consumers skyrocketed between 1999 and 2002, rising from 185 to $427 .{ }^{198}$ Upwards of three percent of wireless consumers had completely "cut the cord" by 2000 , relying solely on their mobile devices for telephony. ${ }^{199}$ By 2002, consumers used more minutes on their cell phones than on their landline phones for the first time ever. ${ }^{200}$ With an increase in consumer demand for more minutes and

190 Third CMRS Report, supra note 186,,at 19753-54 ("The convergence of product and service offerings continues to be a driving force in the wireless industry. Markets are defined by services, not legal or regulatory terms. One of the most easily recognizable results of this process is the increased use of "bundles" (i.e., multiple services from the same device) as a marketing tool. For example, a consumer might purchase a mobile telephone with paging services or a pager that offers voice messaging or data transmission.").

191 See In re Implementation of Section 6002(b) of the Omnibus Budget Reconciliation Act of 1993; Annual Report and Analysis of Competitive Market Conditions With Respect to Commercial Mobile Services, Second Report, 12 F.C.C.R. 11266, 11321 (Mar. 6, 1997).

192 Id. at 19754.

193 Third CMRS Report, supra note186, at 11033 tbl.1.

194 See In re Implementation of Section 6002(b) of the Omnibus Budget Reconciliation Act of 1993; Annual Report and Analysis of Competitive Market Conditions With Respect to Commercial Mobile Services, Sixth Report, 16 F.C.C.R. 13350, 13354, 13362 (July 17, 2001) [hereinafter Sixth CMRS Report].

195 ld. at $13355-56$.

196 Id. at 13356.

197 See Wireless Craze, supra note 163, at 345-47 (comparing the "runaway performance" of NASDAQ during 1998-2000 where "[1]arge wireless equipment suppliers saw annualized returns of $181.2 \%$, wireless broadband operators returned $177.4 \%$ for shareholders, and small wireless broadband suppliers rose an incredible $365.9 \%$ " to $13.63 \%$ per annum return from 1984 to 1998 ).

198 Eleventh CMRS Report, supra note 42, at 11043 tbl.10.

199 Sixth CMRS Report, supra note 194 (citing to Judy Sarles, Wireless users Hanging Up On Landline Phones, Nashville Business Journal (Feb. 2, 2001) http://nashville.bizjournals.com/nashville/stories/2001/02/05/focus2.html; Simon BarkerBenfield, Consumers Replacing Landline Phones with Wireless, FlA. TIMES UNION, Jan. 10, 2001 , at F1.

200 Yankee Group Finds that Wireless Calling Surpasses Wireline Calling. California 
more data-rich mobile services like text messaging and email, along with a concomitant rise in competition among carriers and commitments to upgrade networks to $3 \mathrm{G}$, the private sector demanded additional spectrum to enable the rollout of such services. ${ }^{201}$ In response, the FCC began the process of making additional swaths available for auction. ${ }^{202}$ There was a sense, however, that a more fundamental reexamination of spectrum allocation policies was necessary to ensure that demand for more advanced wireless services (e.g., data services) would be met. ${ }^{203}$

C. The Second Wireless Boom: Spectrum Allocation in the Age of Mobile Data (2002-2006)

In an effort to "keep pace with the ever-increasing demand for spectrum and the continuing advances in wireless technology and applications," the FCC, in 2002, established a Spectrum Policy Task Force (SPTF), an internal effort

Science and Technology News, http://ccnmag.com/article/yankee_group_finds_that_wireless_calling_surpasses_wireline_c alling (last visited Jan. 1, 2011).

201 Sixth CMRS Report, supra note 194, at 50-51; see e.g., Eleventh CMRS Report, supra note 42 , at 11011,11013 .

202 Sixth CMRS Report, supra note 194, at 51-52. "In January 2001, the Commission released a Notice of Proposed Rulemaking exploring the possibilities of using five different spectrum bands for advanced mobile services: $1710-1755 \mathrm{MHz}, 1755-1850 \mathrm{MHz}, 2110$ $2155 \mathrm{MHz}, 2160-2165 \mathrm{MHz}$, and 2500-2690 MHz," citing In re Amendment of Part 2 of the Commission's Rules to Allocate Spectrum Below 3GHz for Mobile and Fixed Services, Including Third Generation Wireless Systems; Petition for Rulemaking of the Cellular Telecommunications Industry Association Concerning Implementation of WRC-2000: Review of Spectrum and Regulatory Requirements for IMT-2000; Amendment of the U.S. Table of Frequency Allocations to Designate the $2500-2520 / 2670-2690 \mathrm{MHz}$ Frequency Bands for the Mobile Satellite Service, Notice of Proposed Rulemaking and Order, 16 F.C.C.R. 596 (Dec. 29, 2000). "[T] hertz of spectrum in the upper $700 \mathrm{MHz}$ band on September 12, 2001. This spectrum is part of a larger band, $698-806 \mathrm{MHz}$, that the WRC-2000 identified for possible implementation of 3G systems," citing In re Service Rules for the 746-764 and 776-794 MHz Bands, and Revisions to Part 27 of the Commission's Rules, First Report and Order, 15 F.C.C.R. 476 (Jan. 6, 2000).

${ }_{203}$ See, e.g., Wireless Craze, supra note 166, at 556-57; see, e.g., Elia Noam, Spectrum Auctions: Yesterday's Heresy, Today's Orthodoxy, Tomorrow's Anachronism. Taking the Next Step to Open Spectrum Access, 41 J.L. \& ECON. 765-90 (1988); LAWRENCE LeSSIG, THE FUTURE OF IDEAS (Random House 2001), available at http://the-future-of-ideas.com (last visited Jan. 1, 2011); Yochai Benkler, Some Economics of Wireless Communications, 16 Harv. J. Law \& Tech. 25 92002); see Jerry Brito, The Spectrum Commons in Theory and Practice, 2007 STAN. TECH. L. REv. 1 (2007), available at http://stlr.stanford.edu/pdf/britocommons.pdf (last visited Jan. 1, 2011); SPTF REPORT, supra note 170, at 1,4; Press Release, FCC, Press Statement of Chairman Michael K. Powell on Spectrum Policy Task Force (Nov. 7, 2002) (on file with author). 
comprised of staff members from an array of departments, ${ }^{204}$ to undertake a comprehensive evaluation of its existing spectrum practices. ${ }^{205}$ The primary responsibility of the SPTF was to recommend more market-oriented policies that would encourage investment, promote innovation, and provide the marketplace with regulatory certainty. ${ }^{206}$

With regard to spectrum allocation, the SPTF recommended a hybrid approach, one that mixed the best elements of a variety of approaches, including the "commons model" 207 and command and control. ${ }^{208}$ New technologies had begun to enhance and maximize the use of spectrum, thus allowing for more capacity to be wrung from individual swaths of spectrum. ${ }^{209}$ This meant that the scarcity argument used to justify the historically rigid command and control approach was being undermined by technological innovation. ${ }^{210}$ Yet spectrum, by its nature, is a scarce and finite resource, ${ }^{211}$ which supports the granting of exclusive rights to swaths of the airwaves. ${ }^{212}$ However, flexible use requirements for individual licensees would allow each to tailor their use in such a way that would increase access to spectrum for other users. ${ }^{213}$ Overall, the task force concluded that a more flexible and market-oriented spectrum policy would create incentives for incumbent market participants to use their spectrum more efficiently and lure new entrants. ${ }^{214}$

204 Press Release, FCC, FCC Chairman Michael K. Powell Announces Formation of Spectrum Policy Task Force (Jun. 6, 2002) (on file with author).

205 See SPTF REPORT, supra note 170, at 1.

206 Id. at 1 . The SPTF invited public comment and held "numerous information meetings as well as four public workshops," in an effort to produce a comprehensive report. Id. at 2.

207 The "commons" model "[a]llows unlimited numbers of unlicensed users to share frequencies, with usage rights that are governed by technical standards or etiquettes but with no right to protection from interference." Id. at 29-30. For additional information on the commons model, see Brito, supra note 203.

208 This has been described as a "hedging" strategy by the FCC. See John S. Leibovitz, The Great Spectrum Debate: A Commentary on the FCC Spectrum Policy Task Force's Report on Spectrum Rights and Responsibilities, 6 YALE J.L. \& TECH. 390, $406-407$ (200304) [hereinafter Great Spectrum Debate].

209 SPTF REPORT, supra note 170, at 15.

210 Id. at 403-05 ("The notion that the scarcity of a wireless system might actually decrease as transmission increases of course turns an assumption underpinning decades of spectrum policy on its head.").

211 Next Frontier of Property Rights, supra note 153, at 556-557 (observing that, even though spectrum is "infinitely renewable," it is "still a scarce resource in the sense that two individuals cannot use the same frequency at the same time in the same place without canceling out-or at least interfering with-both transmissions.").

212 Great Spectrum Debate, supra note 208, at 408-409 (observing four approaches to spectrum allocation available under the framework outlined by the Spectrum Policy Task Force).

213 SPTF REPORT, supra note 170, at 15.

214 Id. 
The idea of flexibility in spectrum use and allocation was certainly not new to the FCC, but innovative technologies and surging consumer demand required a more fundamental reevaluation of how best to optimize the seemingly finite universe of spectrum. ${ }^{215}$ The SPTF recommended the creation of more spectrum rights for individual licensees in response to this dilemma. ${ }^{216}$ These rights included a grant of maximum authority to choose how to use spectrum (i.e., which services to offer), which technology to use to deliver those services, and the ability to transfer, lease or subdivide spectrum in a secondary market free of FCC intervention. ${ }^{217}$ In sum, the SPTF sought to implement a more consistent approach to apportioning spectrum across all bands in the hope that such a framework would "significantly reduce the artificial scarcity of spectrum that currently exists as a result of barriers to access."218 In other words, the SPTF recommended the adoption of policies that would bolster efficient use of spectrum by all licensees. ${ }^{219}$

The SPTF report underscored the FCC's evolving view of the wireless marketplace-market-oriented policies that balanced consumer welfare with the overall public interest. ${ }^{220}$ While acknowledging that there was a role for the FCC in regulating spectrum, the SPTF also recognized the enormous consumer welfare gains being provided to consumers across the United States. In order to ensure continued growth, the FCC understood that it had to either reform its policies or risk impeding the progress of the marketplace. ${ }^{221}$ To this end, the FCC began to implement some of the recommendations in the Task Force's report while it continued to auction new swaths of spectrum to wireless carriers. ${ }^{222}$ For example, in 2003 and 2004, the FCC adopted policies to expand and

215 SPTF REPORT, supra note 170, at 1-4 (discussing the pressures technology places on current spectrum policy and the need for new policy to better utilize available spectrums).

216 Id. at 17.

217 Id.

218 Id. at $9,13,16,21$.

219 Id.

220 For background on the FCC's role in regulating spectrum, see, e.g., SPTF REPORT, supra note 170, at 7-10. See id. at 41 ("To the extent domestic policies and allocations complement international decisions, U.S. consumers and businesses will reap important benefits such as more international roaming and better economies of scale with regard to equipment manufacturing.").

221 Spectrum Bridge, InC., Analysis Of FCC Secondary Spectrum Markets PosiTIONS, POLICIES AND COMMENTS 3 (2008).

222 As then-FCC Chairman Michael Powell noted upon release of the SPTF report, its:

"findings, recommendations and ideas...resonated in this new, technology driven global economy; we can no longer suffer under decades-old spectrum policy regimes that hinder, rather than promote, innovation." As a result, "the Commission ... considered and incorporated the Task Force's findings and recommendations in a number of spectrum allocation and licensing proceedings"

See Press Release, Michael Powell, Fed. Commc'ns Comm'n Chairman, Press Statement 
facilitate the creation of secondary markets in spectrum ${ }^{223}$ and to create incentives for a licensee to maximize the use of their swath of spectrum. ${ }^{224}$ Moreover, the technology necessary for enabling more efficient use of spectrum was beginning to be developed and adopted, ushering the market into what some hoped would be an era of spectrum abundance. ${ }^{225}$

As a result of adopting some SPTF policies and wider technological innovations, the wireless market continued to expand. Between June 2000 and June 2005 , the wireless industry added almost 100 million customers, equal to the amount of users added from the birth of the wireless market to $2000 .{ }^{226}$ Over this same period of time, carriers increased annual investments in networks from $\$ 10$ billion in 2000 to $\$ 20$ billion in $2005 .{ }^{227}$ The number of cell sites increased to 178,025 from 95,733 , and wireless penetration reached sixty-six percent. ${ }^{228}$ Yet the most startling trend was the dramatic rise in wireless data usage.

As the FCC observed in 1997, wireless data applications were poised to become an integral part of the industry. ${ }^{229}$ By June 2000 , annual revenue derived from mobile data was $\$ 139.4$ million; by June 2005 it was $\$ 8.5$ billion, an increase of more than 6,000 percent. ${ }^{230}$ Yet as late as 2003 , the mobile data mar-

Concerning the Spectrum Policy Task Force Report (Nov. 13, 2003), http://hraunfoss.fcc.gov/edocs_public/attachmatch/DOC-241195A2.pdf.

223 In re Promoting the Efficient Use of Spectrum Through Elimination of Barriers to the Development of Secondary Markets, Report and Order, 18 F.C.C.R. 20604, at 20607 (May 15, 2003). In re Promoting Efficient Use of Spectrum Through Elimination of Barriers to the Development of Secondary Markets, Second Report and Order, 19 F.C.C.R. 17503, at 17505-6 (July 8, 2004). A secondary market for spectrum is a mechanism by which unused portions of spectrum could be either leased or assigned by owners to third-parties. The goal of secondary markets is to ensure that spectrum resources are put to maximum use in an effort to increase "opportunities for the development and operation of new services and competition." See In re Principles for Promoting the Efficient Use of Spectrum by Encouraging the Development of Secondary Markets, Policy Statement, 15 F.C.C.R. 24178 (Nov. $9,2000)$.

224 The development of the Commission's approach to secondary spectrum markets has evolved since it first considered the idea in 2000. See id.; In re Promoting Efficient Use of Spectrum through Elimination of Barriers to the Development of Secondary Markets, Report and Order, 18 F.C.C.R. 20604 (May 15, 2003); Second Report and Order, 19 F.C.C.R. 17503 (July 8, 2004); Third Report and Order, 22 F.C.C.R. 7209 (Apr. 6, 2007).

225 See Gregory Staple \& Kevin Werbach, The End of Spectrum Scarcity, IEEE SPECTRUM (Mar. 2004), http://spectrum.ieee.org/telecom/wireless/the-end-of-spectrum-scarcity (last visited Jan. 1, 2011).

226 CTIA Wireless Stats, supra note 28.

227 Id.

228 CTIA Wireless Stats, supra note 28.

229 Third CMRS Report supra note 186, at 3-4.

230 CTIA Wireless Stats, supra note 28. 
ket was still maturing. ${ }^{231}$ That year, the FCC observed that the market for "simple handset-based" mobile applications like text messaging was "more developed" than the market for more advanced services such as Internet access. ${ }^{232}$ Disparate pricing plans and a spate of new services and applications reflected the fledgling nature of this market. ${ }^{233}$ However, during this same period of time, there was a concomitant explosion in demand for broadband services, which increased from 2.5 million in December 1999 to 27.7 million in December 2003. ${ }^{234}$ Along with the trend of wireless telephony substituting for, and in many cases replacing, wireline voice services, ${ }^{235}$ consumers, especially younger ones, showed a demonstrated preference for mobile devices and mobile data in the early $2000 \mathrm{~s}^{236}$

In response to these trends, the FCC auctioned off additional swaths of spectrum in order to speed $3 \mathrm{G}$ network deployment. For example, in 2006 the FCC auctioned off spectrum to further bolster "advanced wireless services" ("AWS"). ${ }^{237}$ This spectrum was reallocated from a variety of users, including the U.S. Department of Defense, ${ }^{238}$ for use by wireless carriers in order to facilitate the deployment of "a wide range of voice, data, and broadband services

231 See Ken Dulaney, Gartner, InC., The Wireless and Mobile Market Starts to MATURE 2-4 (2002) (predicting the ways in which the wireless market would mature in 2003).

232 See In re Implementation of Section 6002(b) of the Omnibus Budget Reconciliation Act of 1993; Annual Report and Analysis of Competitive Market Conditions With Respect to Commercial Mobile Services, Ninth Report, 19 F.C.C.R. 20597, 1117 (Sept. 9, 2004).

233 Id. at 118.

234 Fed. COMmC'ns COMm'N, Industry Analysis and Tech. Div., High-Speed SerVICES FOR INTERNET ACCESS: STATUS AS OF DECEMBER 31, 2006, tbl.10 (2007).

235 See Om Malik, Access Line Losses Hurt: Verizon CEO, GIGAOM.COM (Oct. 30, 2008, 10:34 AM), http://gigaom.com/2008/10/30/access-line-losses-hurt-verizon-ceo/.

236 The Pew Internet \& American Life Project, in 2003, observed that there was a discernible trend in the "growth in consumption of information goods and services," which was being led by a distinct group of active users of technology that Pew broke down into three discrete segments - "Young Tech Elites, the Wired GenXers, and the Older Wired Baby Boomers." See generally, JOHN HORRIGAN, CONSUMPTION OF INFORMATION GOODS AND Services in the United States, PEW InTERnet \& AMERiCAN Life Project (2003).

237 Auction of Advanced Wireless Services, Licenses Scheduled for June 29, 2006, Comment Sought on Reserve Prices or Minimum Opening Bids and Other Procedures, AU Docket No. 06-30 at 1, 4 (Jan. 31, 2006), http://hraunfoss.fcc.gov/edocs_public /attachmatch/DA-06-238A1.pdf; Auction of Advanced Wireless Services Licenses Schedules for June 29, 2006, Notice and Filing Requirements, Minimum Opening Bids, Upfront Payments and Other Procedures for Auction No. 66, 21 F.C.C.R. 4562 at 99 7-8 (Apr. 12, 2006).

238 See Scott Fox \& JefFrey Walkenhorst, Global View Partners, Mobile BROADBAND IN THE AMERICAS: MOMENTUM BUILDING IN THE AWS BAND 10 (2009), available http://www.gsmworld.com/documents/Momentum_Building_in the_AWS_Band.pdf [hereinafter MOMENTUM BUILDING]. 
over a variety of mobile and fixed networks." ${ }^{239}$ This auction-also known as the AWS-1 auction-generated over $\$ 13$ billion in revenue and allocated licenses to over 100 bidders. ${ }^{240}$ However, a number of problems in clearing some swaths of spectrum in this band resulted in the delayed deployment of $3 \mathrm{G}$ network infrastructure. ${ }^{241}$

\section{Arrested Development: FCC Spectrum Allocation Policy Gone Awry (2007-2008)}

The relatively consistent approach to spectrum allocation developed by the FCC over previous decades eventually yielded to a more experimental and uncertain approach in 2007 and 2008 . Four separate proceedings at the FCC, encompassing two large spectrum auctions and an inquiry into unlicensed wireless uses, are illustrative of the turbulence vis-à-vis spectrum policy evident at the Commission in these years.

\section{1. $700 \mathrm{MHz}$ Auction - Rules for the C-Block}

The first example came during the auction of spectrum in the $700 \mathrm{MHz}$ range. ${ }^{242}$ This swath of "beach front" spectrum was freed by broadcasters in their transition from analog to digital transmission. ${ }^{243}$ During the rulemaking process for this auction, which stretched from $2002^{244}$ to $2007,{ }^{245}$ some stake-

239 See In re Amendment of Part 2 of the Commission's Rules to Allocate Spectrum Below $3 \mathrm{GHz}$ for Mobile and Fixed Services to Support the Introduction of New Advanced Wireless Services, including Third Generation Wireless Systems; Service Rules for Advanced Wireless Serivces In the $1.7 \mathrm{GHz}$ and $2.1 \mathrm{GHz}$ Bands, Ninth Report and Order, 24 F.C.C.R. 4473, ๆ 1 (Apr. 12, 2006) [hereinafter AWS-1 Rules].

240 See, e.g., Peter Pollack, FCC Spectrum Auction Moves to Higher Gear, ARS TECHNICA (Aug. 29, 2006, 5:22 PM), http://arstechnica.com/old/content/2006/08/7617.ars; Frank Ahrens, FCC Wireless Auction Could Open Up Airwaves, WASH. PosT, Sept. 19, 2006, at D1.

241 See discussion infra, Part IV.C.

242 See In re Service Rules for the 698-746, 747-762 and 777-792 MHz Bands, Second

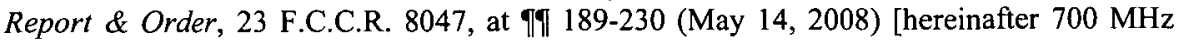
Rules - 2008].

243 Congress Amended DTV Transition Rules in 2005. See Deficit Reduction Act of 2005, Pub. L. No. 109-171, § 3003, 120 Stat. 4 (2006) (Title III of the DRA is the DTV Act).

244 In re Reallocation and Service Rules for the 698-746 MHz Spectrum Band (Television Channels 52-59), Memorandum Opinion and Order, 17 F.C.C.R. 11613 (June 14, 2002).

${ }_{245}$ In re the Matter of Service Rules for the 698-746, 747-762, and 777-792 MHz Bands, et al, Report and Order and Further Notice of Proposed Rulemaking, 22 F.C.C.R. 8064 (Apr. 27, 2007). 
holders sought to use the proceeding as a way to fundamentally reassess the wireless business model and the state of competition in the wireless market. ${ }^{246}$ The concept that resulted from these deliberations, and that was ultimately adopted by the FCC, was "open access." ${ }^{247}$ The open access rules that the FCC imposed on one block of the $700 \mathrm{MHz}$ band - the C-block-"require[d] licensees to allow customers, device manufacturers, third-party application developers, and others to use or develop the devices and applications of their choice, subject to certain conditions." 248 Even though this portion of spectrum was successfully auctioned off to Verizon Wireless, ${ }^{249}$ one study found that the imposition of these rules on this block of spectrum deterred more robust bidding and ultimately cost taxpayers upwards of $\$ 3.1$ billion in lost revenues to the U.S. Treasury. ${ }^{250}$

Moreover, during this lengthy proceeding there was evidence that the wireless market was moving towards more openness on its own. For example, even before the auction, Verizon Wireless announced that it would open its net-

246 Google and Skype, among others, were vocal advocates of using the auction rulemaking as a way to fundamentally alter the wireless business model. Skype, for example, submitted a petition to the FCC in 2007 that requested the "basic connectivity principle" of Carterfone be extended to wireless networks, which would allow a wireless consumer to connect any handset to the network of their choice, among other things. In re Matter of Skype Communications S.A.R.L, Petition to Confirm a Consumer's Right to Use Internet Communications Software and Attach Devices to Wireless Networks, RM-11361 (submitted Feb. 20, 2007). Google used the rulemaking proceeding a way to advocate for using the available spectrum as a "third pipe" to increase broadband access. See Rick Whitt, Tapping the Nation's Airwaves for More Net Access, Google Public Policy Blog, (Apr. 24, 2007, 6:21 PM), http://googlepublicpolicy.blogspot.com/2007/04/by-richard-whitt-washingtontelecom-and.html; In re Service Rules for the 698-746, 747-762 and 777-792 MHz Bands, Google Ex Parte Filing, WC Docket No. 06-150 (submitted May 21, 2007); In re Service Rules for the 698-746, 747-762 and 777-792 MHz Bands, Comments of Google Inc., WC Docket No. 06-150 (submitted May 23, 2007).

247 Nate Anderson, FCC Sets $700 \mathrm{MHz}$ Auction Rules: Limited Open Access, No Wholesale Requirement, ARS TECHNICA (July 31, 2007, 3:32 PM), http://arstechnica.com/old/content/2007/07/fcc-sets-700mhz-auction-rules-limited-openaccess-no-wholesale-requirement.ars; Anne Broache \& Marguerite Reardon, FCC Approves Some Open Wireless Requirements, CNET NEWS (July 31, 2007, 4:56 PM), http://news.cnet.com/FCC-approves-some-open-wireless-requirements/2100-1039_36199990.html.

$248700 \mathrm{MHz}$ Rules - 2008, supra note 242, \ 195.

249 George S. Ford, Thomas Koutsky \& Lawrence J. Spiwak, Phx. Ctr. for AdVANCEd LEgal \& ECON. Pub. POL'y Stud., Using AuCtion REsults to Forecast the IMPACT OF Wireless Carterfone REgulation on Wireless Networks, PHOENIX CEnTER POLICY BULlETIN No. 20, at 2 (2008), available at http://www.phoenix-center.org/Policy Bulletin/PCPB20Final2ndEdition.pdf. [hereinafter IMPACT OF WIRELESS Carterfone REGULATION ON WIRELESS NETWORKS].

$250 I d$. at 3. 
work. ${ }^{251}$ AT\&T also opened its network in late 2007. ${ }^{252}$ The winning bidder of the encumbered C-block has yet to deploy services in this band, ${ }^{253}$ yet, as previously discussed, the wireless ecosystem currently provides for a wide range of "open" activities, e.g., open development of smartphone applications. ${ }^{254}$ In addition, the "closed" business model of the iPhone, which does not allow for open application development, ${ }^{255}$ has proven to be enormously successful and popular among consumers and innovators. ${ }^{256}$ Thus, the FCC's attempt to assure a specific policy outcome-openness-via the imposition of conditions on spectrum use appears to have been ill-conceived given the organic evolution of the wireless market. ${ }^{257}$

\section{2. $700 \mathrm{MHz}$ Auction-Rules for the D-Block}

Second, in addition to adding an open access encumbrance to the C-block of

251 See Marguerite Reardon, Verizon Wireless Opens its Network, CNET News (Mar. 19, 2008, 11:42 AM), http://news.cnet.com/8301-10784_3-9898119-7.html.

${ }_{252}$ See Leslie Cauley, AT\&T Flings Cellphone Network Wide Open, USA TODAY (Dec. 5, 2007, 11:08 PM), http://www.usatoday.com/tech/wireless/phones/2007-12-05-att_N.htm.

253 Sam Churchill, Phoney Spectrum Scarcity, DAILY WIRELESS.ORg (June 18, 2010, 9:52 AM), http://www.dailywireless.org/2010/06/18/phoney-spectrum-scarcity.

254 See, e.g., Matt Assay, In Mobile, Open Source Is a Winning Strategy, CNET News (Oct. 8, 2009, 12:26 PM), http://news.cnet.com/8301-13505_3-10370702-16.html.

255 See, e.g., Jenna Wortham, Apple Lifts the Curtain on App Store Approvals, N.Y.

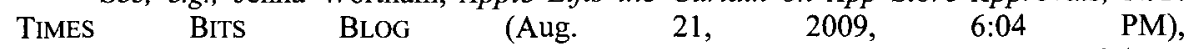
http://bits.blogs.nytimes.com/2009/08/21/apple-lifts-the-curtain-on-app-store-approvals/ (“Apple receives 8,500 new applications and updates to applications each week. The company employs a team of 40 full-time trained reviewers, and each application is independently evaluated by two separate reviewers before getting a green light."); Apple's Game Changer, supra note 74 (observing that Apple has bolstered its review process in order to speed along approvals).

256 See Brian X. Chen, How Microsoft Blew it with Windows Mobile, WIRED.COM GADGET LAB (Nov. 17, 2009, 12:45 PM), http://www.wired.com/gadgetlab/2009/11/microsoftwindows-mobile/. Chen writes:

The iPhone operates on a closed system, which can only run on Apple hardware, meaning third-party developers can produce apps and games that work exclusively with the iPhone. Therefore, despite Apple's questionable and controversial approval policy for iPhone apps, developers can code one app that works with 40 million iPhone and iPod Touch devices, which is less time consuming than developing several versions of one app for a variety of [other] smartphones. In turn, that spells out to a larger number of apps in the App Store, which enables Apple's hardware to cater to a larger and broader audience. Id.

257 The market for smartphone applications is still developing. Application developers and other stakeholders continue to debate the relative merits of more "open" platforms like Android and the more "closed" platform on the iPhone. See, e.g., Mark Sigal, Android vs. iPhone: Why Openness May Not Be Best, GIGAOM.coM (Feb. 22, 2009, 9:00 AM), http://gigaom.com/2009/02/22/is-being-"open"-an-absolute-in-mobile/. 
spectrum during the $700 \mathrm{MHz}$ auction, the FCC initially designated another block-the D-block-for public safety purposes. ${ }^{258}$ As originally conceived, this block of spectrum would be auctioned off to a commercial provider with the understanding that the winning bidders would be required to "partner with public safety constituencies to make use of the adjacent public safety broadband spectrum." 259 However, after multiple rounds of bidding, the auction for the D-block failed to attract a bid that met the reserve price set by the FCC. ${ }^{260}$ An audit of the auction proceedings conducted by the FCC revealed that several stakeholders withheld bids on the D-block because of a number of "uncertainties and risks "stemming from the many usage requirements attached to this particular swath of spectrum. ${ }^{261}$ In 2008, the FCC issued two further notices of rulemaking for the D-block ${ }^{262}$ in the hope that it could devise a framework that resulted in a "nationwide interoperable broadband wireless network for public safety entities." ${ }^{263}$ By the time the FCC issued its National Broadband Plan in early 2010 , the D-block auction remained stalled despite a number of proposals by public safety officials and wireless carriers. ${ }^{264}$ However, the Commission's

$258700 \mathrm{MHz}$ Rules - 2008, supra note 242, ๆ甲 122-24, at 8091 .

259 See Blake Harris, Larger Cities View FCC 700MHz "D Block" Public Safety Plan as Critically Flawed, GOVERNMENT TECHNOLOGY (Oct. 28, 2009), http://www.govtech.com/gt/articles/426176.

260 See, e.g., Stephen Labaton, Wireless Spectrum Auction Raises $\$ 19$ billion, N.Y. Times, Mar. 19, 2008, at C2.

261 See Kent R. Nilsson, FCC, D Block InVESTIGATION 2 (2008), available at http://hraunfoss.fcc.gov/edocs_public/attachmatch/DOC-281791Al.pdf. In particular, these encompassed a number of "uncertainties and risks" stemming from the requisite negotiation and costs associated with actually building out a public safety network. Id.

262 See In re Service Rules for the 698-746, 747-762 and 777-792 Bands; Implementing a Nationwide, Broadband, Interoperable Public Safety Network in the $700 \mathrm{MHz}$, Second Further Notice of Proposed Rulemaking, 23 F.C.C.R. 8047 (May 14, 2008); In re Service Rules for the 698-746, 747-762 and 777-792 Bands; Implementing a Nationwide, Broadband, Interoperable Public Safety Network in the $700 \mathrm{MHz}$ Band, Third Further Notice of Proposed Rulemaking, 23 F.C.C.R. 14301 (Sept. 25, 2008) [hereinafter Third FNPRM-D Block].

263 Third FNPRM-D Block, supra note $262, \uparrow 1$.

264 See Phil Goldstein, What Will Become of the D-Block?, FIERCEWIRELESS.COM (Sept. 17, 2009, 10:44 AM), http://www.fiercewireless.com/story/what-will-become-d-block/200909-17. Goldstein notes that

[a] coalition of public-safety organizations - with the hefty backing of AT\&T and Verizon Wireless-have coalesced around a proposal that asks Congress to direct the FCC to allocate $10 \mathrm{MHz}$ of spectrum in the $\mathrm{D}$ Block directly to the public-safety community in regional chunks. The organizations would then choose private companies through a request for proposal bidding process to build out the network.

Id.

Other carriers, e.g., T-Mobile, have recommended that the FCC should auction off the Dblock for commercial uses and use the proceeds to "fund the build-out and maintenance of a nationwide, interoperable public-safety network." See Comments of T-Mobile, In re Na- 
Plan envisions a nationwide public safety broadband network undergirded by spectrum in the D-block. ${ }^{265}$ To this end, the FCC expects to auction this spectrum by early $2011 .^{266}$

\section{AWS-3 Auction \& The "Free" Broadband Requirement}

The third example stems from a rulemaking for an auction of spectrum in the AWS-3 band. In the AWS-3 auction, much like in the $700 \mathrm{MHz}$ proceeding, the FCC sought to attach a usage condition to a portion of the spectrum ahead of the auction. In particular, the FCC proposed the imposition of a "free" broadband rule, which would have required the winning bidder to "provide free, two-way broadband Internet service including . . . data rates of at least $768 \mathrm{kbps}$ downstream using up to 25 percent of the licensee's network capacity" and to "provide for open devices for its free service." ${ }^{267}$ The FCC received a spate of comments in this proceeding arguing against this rule for a number of reasons, including that such encumbrances and conditions ultimately devalue the spectrum ${ }^{268}$ and slow innovation because it limits the choices a provider can make for using it. ${ }^{269}$ Others viewed the "free" broadband encumbrance as a way of spurring network deployment to unserved parts of the country. ${ }^{270}$ Ultimately, the FCC decided against moving forward with the "free"

tional Broadband Plan for our Time, Public Notice \#6, at 14-15 (submitted Oct. 23, 2009).

265 National BroadBand PlaN, supra note 11, at 76, 316.

266 See Fed. COMMn'CNS COMm'N, BROAdBAND ACTION Agenda 2, available at $\mathrm{http} / / / \mathrm{www}$.broadband.gov/plan/national-broadband-plan-action-agenda.pdf (noting that by "late Q2 or early Q3 2010" the FCC will "adopt an order and [Notice of Proposed Rulemaking] to pave the way for an auction of the $10 \mathrm{MHz}$ of spectrum in the ... D Block in the first half of 2011.").

${ }^{267}$ In re Service Rules for Advanced Wireless Services, Further Notice of Proposed Rulemaking, 23 F.C.C.R. 9859, $\$ 3$.

268 See George Ford, Calculating the Value of Unencumbered AWS-III Spectrum 3 (PHOENIX CENTER PERSPECTIVES 2008) available at http://www.phoenixcenter.org/perspectives/Perspective08-01Final.pdf [hereinafter Value of Unencumbered AWS-III Spectrum] (estimating the cost of unencumbered AWS-III spectrum would be in the "upper \$2 billion range" and that, even though no prediction was offered regarding how much the encumbrances might devalue the spectrum, "I see no reason to believe such a substantial discount would not appear in the AWS-III auction given the proposed conditions.").

269 Thomas M. Lenard, Lawrence J. White \& James L. Riso, Tech. Policy. Inst., INCREASING SPECTRUM FOR BROADBAND: WhAT ARE THE OPTIONS? i (2010) (commenting that " $[\mathrm{t}]$ he growth of wireless broadband is a bright spot in the U.S. economy, but a shortage of flexibly licensed spectrum rights could put a crimp on this expansion.").

270 See, e.g., Jeffrey Silva, FCC Again Urged to Vote on AWS-3 Plans: Spectrum Auction on Hold, RCR WIRELESS NEWS (Dec. 18, 2008, 1:47 PM), http://www.rcrwireless.com/ARTICLE/20081218/WIRELESS/812189989/fcc-again-urgedto-vote-on-aws-3-plans; Nancy Gohring, Lawmakers Urge FCC to Move Forward with 'Free' Plan, PC WorLd, (Aug. 11, 2008, 4:00 PM), 
broadband encumbrance for AWS-3 and will instead attempt to pair this swath of spectrum with other portions of the airwaves in order to provide innovators with more robust wireless resources. ${ }^{271}$

\section{Unlicensed Wireless Uses via the "White Spaces"}

Fourth, in late 2008 the FCC approved the use of "white spaces" for wireless broadband purposes. White spaces are "unused airwaves that abut broadcast TV spectrum, providing a buffer zone from stray signals and other interference." ${ }^{272}$ These slivers of the airwaves could, in the aggregate, provide " $300 \mathrm{MHz}$ and $400 \mathrm{MHz}$ of unlicensed spectral capacity throughout the country." 273 The FCC order would allow for the "development of new and innovative types of unlicensed devices."274 Given the characteristics of this portion of the airwaves-it is national in scope and able to "easily penetrate obstacles such as buildings and trees and can reach longer distances than the higher frequencies currently utilized by unlicensed Wi-Fi devices"--some have argued that these bands can be used to facilitate rural broadband deployment and otherwise bolster affordable broadband access across the United States. ${ }^{275}$ However, despite the potential upside for devices and services enabled by the freed white spaces, there are concerns that the continued proliferation of unlicensed access to spectrum could inadvertently skew the market and undercut the investments and innovations of service providers who paid billions to secure exclusive spectrum rights. ${ }^{276}$ The FCC finally adopted rules to govern use of the white spaces in $2010 .^{277}$

http://www.pcworld.com/businesscenter/article/149693/lawmakers_urge_fcc_to_move_for ward_with_free_plan.html.

${ }^{271}$ See Nancy Gohring, FCC Strikes Down Free Broadband Plan, COMPUTER WORLD,

$\begin{array}{llll}\text { (Sept. } & 1, & 2010, & 3: 20\end{array}$ http://www.computerworld.com/s/article/9183220/FCC_strikes_down_free_broadband_plan ?taxonomyId=16\&pageNumber $=1$.

272 See Leslie Cauley, FCC Approves 'Whites Spaces' for Broadband, USA TODAY (Nov. 14, 2008), http://www.usatoday.com/tech/news/2008-1 1-04-white-space_N.htm.

273 See Marguerite Reardon, Broadcasters Challenge FCC 'White Spaces' Report, CNET

NEws (Oct. 17, 2008, 7:52 PM), http://news.cnet.com/8301-1035_3-10069428-94.html.

274 See In re Unlicensed Operation in the TV Broadcast Bands; Additional Spectrum for Unlicensed Devices Below $900 \mathrm{MHz}$ and in the $3 \mathrm{GHz}$ Band, Second Report and Order and Memorandum Opinion and Order, 23 F.C.C.R. 16807, 12 (Nov. 4, 2008).

275 See Sascha D. Meinrath \& Michael Calabrese, "White Space Devices" \& the Myths of Harmful Interference, 11 N.Y.U. J. LEGIS. \& PUB. POL'Y 495, 500-501 (2008).

276 See Priya Ganapati, FCC White Spaces Decision Kicks Off the Next Wireless Revolution, WIRED GADGET LAB (Nov. 5, 2008, 12:45 PM), http://www.wired.com/gadgetlab/2008/1 1/fccs-decision-t/.

277 See In re Unlicensed Operation in the TV Broadcast Bands; Additional Spectrum for Unlicensed Devices Below $900 \mathrm{MHz}$ and in the $3 \mathrm{GHz}$ Band, Second Memorandum Opinion 


\section{E. Maturation: A Renewed Commitment to Bolstering Spectrum Access (2009-present)}

In 2009, the FCC began a forward-looking, comprehensive review of the wireless market from a variety of vantages. First, the Commission issued a series of notices of inquiries (NOIs) focused on the wireless market generally.

The first NOI focused on "fostering innovation and investment in the wireless communications market" and was issued in order to "further [the FCC's] understanding of where and how key innovations are happening across the full "value chain" of the wireless market, including spectrum utilization, technologies, business models, and services." 278

The second NOI focused on how to refine the FCC's approach to analyzing the wireless market and how the Commission might "expand [its] understanding of the mobile wireless industry" by broadening its traditional inquiry to include additional data sources and "market segments not covered thoroughly in previous [mobile competition] reports."279

The third NOI requested comments regarding whether or not the FCC needed to update its consumer policies in light of recent technological changes and innovations. ${ }^{280}$

During the development of its National Broadband Plan, the Commission issued two public notices ("PN") specifically focused on reforming its spectrum allocation policy. The first PN sought comment on "the fundamental question of whether current spectrum allocations . . . are adequate to support near-term and longer-term demands of wireless broadband."281 The second PN sought data on a variety of different spectrum uses and their impacts on satisfying near-and long-term demand. ${ }^{282}$

These PNs and other public comments informed the final version of the Plan. In addition to the Plan's many spectrum-specific recommendations, which are discussed in more detail infra, the document made a series of prom-

and Order, FCC 10-174, ET Docket No 04-186, ET Docket No. 02-380, at 11 , (Sep. 23, 2010), available at http://www.fcc.gov/Daily_Releases/Daily_Business/2010/db0923/FCC10-174A1.pdf.

278 FCC Wireless Innovation NOI, supra note 62, ๆ 4.

279 See In re Implementation of Section 6002(b) of the Omnibus Budget Reconciliation Act of 1993; Annual Report and Analysis of Competitive Market Conditions With Respect to Commercial Mobile Services, Notice of Inquiry, 24 F.C.C.R. 11357, 15 (Aug. 27, 2009).

280 See In re Consumer Information and Disclosure, Notice of Inquiry, 24 F.C.C.R. 11380 , ๆ 3 (Aug. 28, 2009) (updating the FCC's consumer policies in light of recent technological changes and innovations).

281 See Comment Sought on Spectrum for Broadband NBP Public Notice \# 6, Public Notice, 24 F.C.C.R. 12032, 19 1-2 (Sept. 23, 2009) [hereinafter FCC Spectrum PN].

282 See Data Sought on Uses of Spectrum NBP Public Notice \# 26, Public Notice, 24 F.C.C.R. 14275, ๆף 1-2 (Dec. 21, 2009); see also infra Part IV.B. for further discussion. 
ising observations about the need for modernizing the Commission's overall approach to managing the nation's airwaves. ${ }^{283}$ In particular, the FCC observed that:

[B]ecause mission needs and technologies evolve, there must be a public review process to ensure that decisions about federal and non-federal [spectrum] use that may have worked in the past can be revisited over time. In general, where there is no overriding public interest in maintaining a specific use, flexibility should be the norm. ${ }^{284}$

Such flexibility is essential to spurring additional network deployments and upgrades, which in turn will spur continued innovation at the edges of the network. ${ }^{285}$

In some cases, notably the auction of spectrum in the C- and D-blocks of the $700 \mathrm{MHz}$ band and in the AWS-3 band, the FCC has demonstrated a willingness to control spectrum usage in order to ensure a particular outcome (i.e., open access, a nationwide public-safety system and broadband deployment, respectively). ${ }^{286}$ In other cases, notably the series of NOIs it issued in 2009 and the final version of its National Broadband Plan, the Commission has shown a more thoughtful approach to modernizing its approach to spectrum. However, the market has continued to rapidly evolve, oftentimes at a faster pace than FCC inquiries or rulemaking. Best intentions aside, the FCC has struggled in recent years to fashion an appropriately forward-looking spectrum allocation framework that is flexible enough to accommodate the brisk pace of innovation and competition of the wireless market.

\section{F. Lessons Learned}

Four observations stemming from the preceding historical analysis provide policymakers with potential best practices for forging new spectrum allocation policies that seek to support continued innovation across the entire wireless ecosystem. First, the FCC has generally made additional spectrum available in a timely manner to facilitate continued innovation and network deployment. ${ }^{287}$ Over the past 15 years, the FCC has conducted some 88 auctions for spectrum. ${ }^{288}$ As of December 2010, seven additional auctions were either scheduled

283 National BROADBAND Plan, supra note 11 , at 78.

284 Id. (emphasis added).

285 Id. at 77 ("If the U.S. does not address [growing spectrum needs] promptly, scarcity of mobile broadband could mean higher prices, poor service quality, an inability for the U.S. to compete internationally, depressed demand, and, ultimately, a drag on innovation.").

286 Ellen Goodman, Spectrum Auction and The Public Interest, 7 J. Telecomm. \& HigH TECH. L. 343, 343-45 (2009).

287 Kathleen Q. Abernathy et al., Major Wireless Policy Developments, September 2008 - September 2009, 990 PraC. LAW INST. 125, 148 (2009).

288 See generally Auctions Summary, FED. COMMC'NS COMM'N, 
or waiting to be scheduled for some future date. ${ }^{289}$ However, as discussed below, the amount of spectrum readily available for auction in the near-term will not meet the demands of innovators. ${ }^{290}$ But the $\mathrm{FCC}$ has acknowledged this shortcoming and has pledged to rectify it in a timely manner. ${ }^{291}$

Second, the FCC has generally kept the regulatory hand off the wireless market, deferring to market forces to provide welfare gains. ${ }^{292}$ However, as discussed above, there have been cases where the FCC has tried to impose its own policy agenda in lieu of actual consumer demand, mostly by encumbering spectrum with rules that attempt to ensure a certain outcome. ${ }^{293}$ The result has been a devaluation of spectrum ${ }^{294}$ and regulatory uncertainty as the FCC sends mixed signals to wireless innovators regarding the exact role of the Commission in the modern marketplace. ${ }^{295}$ Thus, spectrum allocation policies should be adjusted to reflect actual market conditions. Moreover, spectrum should not be encumbered with conditions that seek to achieve certain policy outcomes. Such policies could deter investment, ${ }^{296}$ stifle innovation, slow network deployments, and undermine ownership rights in spectrum. ${ }^{297}$

http://wireless.fcc.gov/auctions/default.htm?job=auctions_all (follow "Completed Auctions" hyperlink) (last updated Dec. 15, 2010).

289 Id.

290 See infra, Part IV.A.

291 See Blair Levin, You Can't Coach Height: A Winning Spectrum Strategy, FCC BLoGBand: The Official Blog of the National Broadband Plan (Oct. 29, 2009), $\mathrm{http} / / /$ blog.broadband.gov/?entryld=10624 (noting that the many innovations and advancements predicted by many stakeholders in the wireless market cannot happen "without spectrum"); Genachowski Remarks-April 13, 2010, supra note 13, at 3-5 (discussing the serious lack of spectrum to meet future "mobile Internet access" demands and how the National Broadband Plan will solve the problem).

292 See Tony Clark \& Michael J. Santorelli, Advanced Commc'ns L. \& Pol'y Inst., Federalism IN Wireless Regulation: A New MOdel fOR A New World 5-6 (2009), http://www.nyls.edu/user_files/1/3/4/30/83/Clark \& Santorelli - Wireless Federalism - February 2009.pdf (discussing the impact of a deregulatory approach to wireless on competition, innovation, and consumer welfare).

293 See supra, Part III.D.

294 Value of Unencumbered AWS-III Spectrum, supra note 268; IMPACT OF WIRELESS Carterfone REGULATION ON WIRELESS NETWORKS, supra note 249. An analysis of auctions from the early 1990s found that heavily encumbered spectrum resulted in more tentative bidding by companies. See Peter C. Cramton, The FCC Spectrum Auctions: An Early Assessment 6 J. of ECON. \& MGMT. STRATEGY 431-495 (1997).

295 LOSING THE FOREST, supra note 25, at 19-22 (discussing the impact of regulatory certainty on innovation in the wireless marketplace).

296 NeT NeUTRALITY, INVESTMENT \& JOBS, supra note 5, at 26-33 (assessing the negative impacts of proposed network neutrality and Title II regulations on broadband service provider business models).

297 See, e.g., Thomas W. Hazlett, A Law \& Economics Approach to Spectrum Property Rights: A Response to Weiser \& Hatfield, 15 GeO. MASON L. Rev. 975, 1004-1015 (2008) [hereinafter Spectrum Property Rights] (comparing and contrasting the spectrum allocation 
Third, the FCC has acknowledged that spectrum allocation policy must evolve along with the market. ${ }^{298}$ The SPTF convened in the early 2000 s was a high point of internal self-reflection and yielded useful, forward-looking policies for ensuring continued growth of the wireless market. ${ }^{299}$ For example, secondary markets for spectrum were expanded and bolstered by the SPTF. ${ }^{300}$ These markets have been moderately successful in creating new opportunities for innovators to access additional swaths of spectrum. ${ }^{301}$ As one commentator has observed, one current success of secondary spectrum markets has involved educational licensees:

"The FCC ... allowed the educational licensees, subject to certain conditions, to lease the right to operate under those licenses to commercial providers. Companies such as Sprint/Nextel and Clearwire . . . have taken many such leases. Although the terms are private, one indication of the success of this plan is the more than one thousand lease notifications on file with the FCC." 302

These types of comprehensive spectrum policy reviews often result in new frameworks that favorably position the wireless market for continued innovation. ${ }^{303}$ In addition, these reviews have important direct and indirect impacts on the amount of spectrum available to innovators.

Fourth, the FCC is not immune to backsliding in its approach to allocating spectrum or to adjusting its agenda to support specific outcomes. ${ }^{304}$ The Com-

approach in the cellular market, which has a relatively liberal spectrum policy, and the broadcast TV market, which has a relatively restrictive licensing model with more encumbrances attached to licenses. Hazlett observes that "Cellular's productive activities, efficiently organized via market transactions that dynamically reconfigure spectrum rights to seize evolving opportunities, contrasts with broadcasting's common interest tragedies," and concludes that "When liberal licenses supply the spectrum rights necessary for productive market transactions, economic incentives generate rational tradeoffs.").

298 Spectrum Allocation, Assignment and Enforcement, FED. CoMmC'NS COMM'N, http://www.fcc.gov/connectglobe/sec7.html (last visited Jan. 1, 2011).

299 Michael K. Powell, Chairman, Fed. Commc'ns Comm'n, Broadband Migration III: New Directions in Wireless Policy, Remarks at the Silicon Flatirons Telecommunications Program at University of Colorado at Boulder (Oct. 30, 2002).

300 See James B. Speta, Spectrum Policy Experiments: What's Next?, 2008 U. CHI. LEGAL F. 389, 395 (2008).

301 In re Promoting Efficient Use of Spectrum Through Elimination of Barriers to the Development of Secondary Markets, Second Report and Order, Order on Reconsideration, and Second Further Notice of Proposed Rulemaking, 19 F.C.C.R. 17503, 19 1-3 (July 8, 2004).

302 See Speta, supra note 300 , at 393.

303 The FCC announced the launch of another Spectrum Task Force in May 2010. The Task Force will "will play a critical role in the execution of the spectrum recommendations in the National Broadband Plan, including long-term spectrum planning." See Press Release, Fed. Commc'ns Comm'n, FCC Chairman Julius Genachowski Announces Launch of Spectrum Task Force (Apr. 26, 2010), available at http:/hraunfoss.fcc.gov/edocs_public/attachmatch/DOC-297722A1.pdf.

304 See Philip Weiser, Institutional Design, FCC Reform, and the Hidden Side of the 
mission has long been accused of being susceptible to "regulatory capture," which further compounds the perceived vulnerability of this agency to the demands of special interests and limits its ability to undertake bold action. ${ }^{305}$ However, recent action by the Commission on this point suggests that the FCC is addressing these shortcomings and implementing policies that support openness and transparency. ${ }^{306}$ To this end, the various inquiries initiated in 2009 in conjunction with the development of the National Broadband Plan were among the most inclusive and open on record, and could ultimately result in a valuable set of forward-looking wireless policies. ${ }^{307}$ Thus, open, transparent, and inclusive rulemakings, and other policy proceedings that are data-driven, tend to yield effective policies that provide stakeholders with regulatory certainty. ${ }^{308}$

Keeping in mind the lessons of the past while creating a forward-looking set of proposals for spectrum allocation will result in a policy framework that allows the wireless market-including its millions of subscribers and the everincreasing number of innovators that contribute to a vibrant mobile ecosystem-to continue fostering competition, enabling innovation, and producing cutting-edge services and applications.

\section{TURNING POINT: RECOMMENDATIONS FOR A 21ST CENTURY SPECTRUM ALLOCATION POLICY}

A surfeit of oftentimes contradictory proposals for revising the FCC's spectrum allocation policy has been offered over the last few years. Some have

\footnotetext{
Administrative State, 61 ADMIN. L. R. 675, 692 (2009).

305 See, e.g., id., at 683-684 (2009) (citing former FCC staff criticisms of the agency's vulnerability to capture and observing that "the FCC's challenge is not so much the classic portrait of agency capture (e.g., the revolving door) or even the more subtle version of the intertwined interests model (i.e., taxation by regulation) advanced by [Judge Richard] Posner. Rather, it is the agency's institutional limitations - a failure to approach issues strategically, to develop independent solutions, and to anticipate issues ahead of particular crises that often lead it to miss opportunities to chart independent courses of action ....").

306 See, e.g., Julius Genachowski, Chairman, Fed. Commc'ns Comm'n, Remarks to the Staff of the Federal Communications Commission (June 30, 2009), available at http://hraunfoss.fcc.gov/edocs_public/attachmatch/DOC-291834Al.pdf (noting that the FCC will be "open and transparent"); In re Amendment of the Commission's Ex Parte Rules and Other Procedural Rules, Notice of Proposed Rulemaking, FCC 10-31, GC Docket No. $10-43$, โT 1-2 (Feb. 18, 2010) (soliciting comment on enhancing participation in FCC rulemaking proceedings).

307 See Recent FCC Broadband Initiatives, FED. COMMC'NS COMM'N (July 9, 2009), http://www.fcc.gov/cgb/consumerfacts/broadband_initiatives.html; FCC to Release Ambitious but Pragmatic, National Broadband Plan, WIRED.COM (Mar. 15, 2010, 5:48 PM), http://www.wired.com/epicenter/2010/03/fcc-ambitious-broadband-plan/.

308 National BroadBand Plan, supra note 11, at 37, 52.
} 
theorized that alternative spectrum allocation approaches such as open spectrum or heavily encumbering spectrum with onerous usage requirements, could produce significant consumer welfare gains, ${ }^{309}$ while others have argued that the imposition of policies that further this experimentation with valuable portions of the continually shrinking airwaves risks impeding the organic innovation described above. ${ }^{310}$ Some predict that promoting unlicensed wireless devices will result in "less expensive and more readily deployable forms of wireless service." 311 Many counter by saying that strong spectrum property rights are essential to supporting continued innovation. ${ }^{312}$ Still others have proposed a middle-ground approach that combines a more open "commons" model with traditional property rights. ${ }^{313}$ Despite an array of differences, these and many other proposals do share one common thread: the FCC's spectrum allocation regime needs to fundamentally change in order to accommodate further market growth and innovation. Such a policy shift must be framed around the concept of supporting the current wireless ecosystem, applying historical best practices to spectrum allocation that have proven to be effective, building sufficient flexibility into the FCC's wireless regulatory approach, and fostering a competitive and innovative environment going forward.

\section{A. Appreciate the Scale \& Scope of the Looming Spectrum Crisis}

As discussed above, mobile data usage continues to increase across all user groups and demographics. ${ }^{314}$ Indeed, Nielsen reported that mobile data usage

309 See, e.g. Michael Calabrese, The End of Spectrum Scarcity: Building on the TV Bands Database to Access Unused Public Airwaves, (New Am. Found. Working Paper No. 25, 2009), (advocating for an open spectrum model that would maximize utilization of the nation's airwaves) [hereinafter End of Spectrum Scarcity]. available at http:/www.newamerica.net/files/Calabrese_WorkingPaper25_EndSpectrumScarcity.pdf

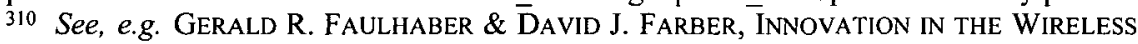
Ecosystem: A CuSTOMER-CENTRIC FRAMEWORK 1-4, [hereinafter CuSTOMER-CENTRIC FRAMEWORK], available at http://fjallfoss.fcc.gov/ecfs/document/view?id=7020039960 (arguing that "there is no market failure [in the wireless sector] which would necessitate market intervention by the FCC.").

311 See, e.g., Harold Feld, From Third Class Citizen to First Among Equals: Rethinking the Place of Unlicensed Spectrum in the FCC Hierarchy 15 COMMLAw CONSPECTUS 53, 54 (2006) (noting unlicensed deployments tend to be less reliable than licensed deployments and more prone to interference).

312 Next Frontier of Property Rights, supra note 153; Spectrum Property Rights, supra note 297.

313 See, e.g., Ellen Goodman, Spectrum Rights in the Telecosm to Come, 41 SAN DIEGo L. REV. 269, 379-80 (2004) (outlining how such an approach might work in practice).

314 See Women, Teens, and Seniors Help Fuel 34\% Mobile Web Spike, NIELSENWIRE (Sept. 30, 2009), http://blog.nielsen.com/nielsenwire/online_mobile/mobile-web-up-34percent-july-09/. 
increased 34 percent between 2008 and 2009. ${ }^{315}$ Growth was observed across every age group, with adults over the age of 65 experiencing the largest growth rate. ${ }^{316}$ Data usage among people with disabilities also continues to increase ${ }^{317}$ and certain minority groups, particularly African-Americans and Hispanics, utilize mobile devices for Internet access much more frequently than other demographic groups. ${ }^{318}$ Overall, Cisco estimates that mobile data traffic will increase some sixty-six times by $2013 .{ }^{319}$ In the U.S., demand for mobile Internet services is expected to increase forty-fold between 2010 and $2015 .^{320}$

These upward trends in usage by individual subscribers, coupled with the increasing integration of wireless broadband into sectors like healthcare and energy (as discussed in Part II.B.2), undergird projections for the amount of spectrum that is needed to support more intensive use and innovation across all sectors of the economy. ${ }^{321}$ To this end, several organizations have estimated that a large amount of spectrum must be made available in order to support more intensive network usage by consumers and entire sectors of the economy. For example, in 2006 the International Telecommunications Union (ITU) issued a report that called for a substantial amount of new spectrum to support new innovations and deployments. ${ }^{322}$ Indeed, the ITU predicted that "[b]ased

315 Id.

316 Senior mobile data usage increased sixty-seven percent between 2008 and 2009. This large spike, however, is due to a very low percentage of older adults using mobile data. As of 2009 , only three percent of adults over sixty-five used mobile data services. $I d$.

317 A 2009 study by the Wireless Rehabilitation Engineering Research Center (RERC) found that "wireless information and communications technologies play an increasing role in education, employment, healthcare, and other aspects of independent living for people with and without disabilities." See Background: Addressing a Significant Need, WIRELESS RERC, http:/www.wirelessrerc.org/about-us/background-addressing-a-significantneed.html (last visited Jan. 1, 2011). A recent survey by the Wireless RERC found that after voice communications, text messaging, email, and Internet access were the most important uses of a cell phone among people with disabilities. See SECOND REPORT: FINDINGS OF THE SURVEY OF USER NEEDS (SUN) FOR WIRELESS TECH., 2007-2009 2 (2009), available at http://www.wirelessrerc.org/publications/SUN Second Findings Report_2009-03-25.doc.

318 PEW WIRELESS STUDY 2009, supra note 22, at 29 (finding these two demographic groups are more likely to participate I most mobile data activities than Whites); see id. at 33 (observing African-Americans are "[seventy percent] more likely to [access the Internet on a wireless device on a typical day] than white Americans.").

319 Cisco Visual NetworkIng INDEX, supra note 38; see Brad Reed, Cisco: Mobile Data Traffic to Grow 66-Fold by 2013, NETwORK WORLD (Feb. 11, 2009, 2:27 PM), http://www.networkworld.com/news/2009/02/109-cisco-mobile-data-traffic.html.

320 Genachowski Remarks-April 13, 2010, supra note 13, at 4.

321 Supra Part II.B.2.

322 See Estimated Spectrum Bandwidth Requirements for the Future Development of IMT-2000 and IMT-Advanced, INTERNATIONAL TELECOMMUNICATIONS UNION (ITU), Report ITU-R M.2078, at 25 (2006), available at http://www.itu.int/dms_pub/itu-r/opb/rep/R-REPM.2078-2006-PDF-E.pdf (estimating that an additional $1,300 \mathrm{MHz}$ of spectrum would be needed by 2015). 
on current trends . . . in the next 12 years the mobile industry will utilize three times more spectrum than in the last 20 years." ${ }^{323}$ Similarly, 3G Americas has observed that "with the projected increase in the use of mobile-broadband technologies, the amount of spectrum required by the next generation of wireless technology . . could be substantial." ${ }^{324}$ CTIA-The Wireless Association considered these various proposals and called for the allocation of $800 \mathrm{MHz}$ of spectrum in order to "meet[] rapidly increasing demand" for wireless services. ${ }^{325}$

Despite the high demand for spectrum by innovators, spectrum is in short supply. CTIA has estimated that wireless service providers currently "operate with just under $450 \mathrm{MHz}$ of spectrum," which is much less than the spectrum available to innovators in other developed nations, and that only $40 \mathrm{MHz}$ of spectrum is "in the pipeline" for use by network operators. ${ }^{326}$ However, there is a growing appreciation among policymakers for the possibility of a spectrum shortage as the United States fully transitions to a society and economy defined by wireless broadband-enabled transactions and services. ${ }^{327}$ Indeed, the FCC has acknowledged that even though the FCC has "authorized a 3-fold increase in commercial spectrum" over the last several years, "many anticipate [a dramatic increase] in wireless traffic," which presages a potential "spectrum gap." 328

323 Momentum BuILDING, supra note 238 , at 8.

324 BROADBAND Evolution TO 4G, supra note 48, at 21.

325 See In re A National Broadband Plan for Our Future, Written Ex Parte Communication of CTIA - The Wireless Association, GN Docket No. 09-51, at 1 (Sept. 29, 2009) (accessible via FCC Electronic Comment Filing System).

326 Comment Sought on Spectrum for Broadband, Public Notice, 24 F.C.C.R. 12032, 12034 (Sept. 23, 2009) (citing comments filed by CTIA in the Commission's national broadband docket on June 8, 2009).

327 See Ann Compton, Yunji de Nies \& Sunlen Miller, The Spectrum Crunch: President Obama Takes on the Shortage of Wireless Capacity, ABC NEwS.COM (June 28, 2010, 9:49 AM), http://blogs.abcnews.com/politicalpunch/2010/06/-the-spectrum-crunch-presidentobama-takes-on-the-shortage-of-wireless-capacity.html; see also Tim Conneally, Legislation Begins on the Next Great Spectrum Shift, BETANEWS.COM (Dec. 15, 2009, 1:16 PM), http://www.betanews.com/article/Legislation-begins-on-the-next-great-spectrum-

shift/12609091014 (citing Steve Largent, President and CEO of CTIA - The Wireless Association, "[T]here is less than $500 \mathrm{MHz}$ of commercial spectrum available for commercial deployments, and that the demand is expected to exceed $1300 \mathrm{MHz}$."); Stacey Higginbotham, Spectrum Shortage Will Strike in 2013, GigaOM (Feb. 17, 2010, 1:00 PM), http://gigaom.com/2010/02/17/analyst-spectrum-shortage-will-strike-in-2013/.

328 Genachowski Wireless Remarks-Oct. 7, 2009, supra note 12, at 5; see Charles Mathias, Is There Enough Spectrum?, FCC BlogBand (Oct. 6, 2009), http://blog.broadband.gov/?entryId=10878 ("The amount of spectrum available for use for broadband devices is crucial in determining an overall national broadband plan. With the continued rise of the use of smartphones, and the needs for spectrum associated with their use, we have to look to the future availability of spectrum and where that spectrum is lo- 
The Commission's various inquiries and proceedings related to spectrum signal a strong commitment to reforming its allocation policy, but there appears to be tension between the amount of spectrum needed by innovators and the time it will take to make that spectrum available. ${ }^{329}$ As a result, a clear framework for identifying, clearing, and making available viable swaths of the airwaves to innovators is needed to assure continued innovation.

\section{B. Undertake a Comprehensive \& Rapid Inventory of the Airwaves}

A key component of a new spectrum allocation framework will be a comprehensive effort to understand how the airwaves are currently being used. Without a thorough comprehension of how this scarce resource is utilized, the possibility exists that spectrum will be inefficiently used or squandered. ${ }^{330}$ Moreover, the speed with which such an inventory is completed is critical to making new swaths available to mobile broadband providers in a timely manner. ${ }^{331}$ However, the completion of an inventory should not delay efforts focused on reallocating or otherwise making additional spectrum available to innovators.

Currently, both the FCC and the National Telecommunications and Information Administration (NTIA) have responsibility for administering and monitoring spectrum in the United States. The NTIA oversees spectrum use by the

cated.'); Kim Hart, FCC to Release Broadhand Airwaves in Big Win for Cell Phone Companies, HilliCON VALLEY (Feb. 23, 2010, 6:50 PM), http://thehill.com/blogs/hilliconvalley/technology/83263-fcc-to-release-airwaves-in-big-win-for-cell-phone-companies ("FCC Chairman Julius Genachowski has repeatedly warned of an impending spectrum shortage that could hinder the United States' efforts to stay competitive in the broadband market."); Genachowski Remarks-April 13,2010, supra note 13, at 4.

329 See Allie Winter, $3 G$ Buildouts Tied to Spectrum Availability, RCR WiRELESS NEWS (Oct. 16, 2008, $16: 00 \quad$ AM), http://www.rcrwireless.com/article/20081016/WIRELESS/810139966/3g-buildouts-tied-tospectrum-availability.

330 See New america foundation, Dupont Circle Spectrum Utilization During Peak Hours: A Collaborative EfFort of the New america Foundation and the SHARED SPECTRUM COMPANY 4 (2003), available at http://www.newamerica.net/files/archive/Doc_File_183_1.pdf (arguing the current spectrum allocation and utilization policies can lead to a "fundamentally broken and inefficient" use of the resource).

331 See, e.g., John Eggerton, Spectrum Inventory Bill Fails to Pass on Unanimous Consent, BROAD. \& CABLE.COM (Apr. 14, 2010, 1:06 PM), http://www.broadcastingcable.com/article/451466-

Spectrum_Inventory_Bill_Fails_To_Pass_On_Unanimous_Consent.php; see also Conneally, supra note $3 \overline{27}$ (discussing how the two upcoming bills, H.R. 3019 and H.R. 312, are aimed to "speed up the inventory and reallocation of spectrum" and explains how the two are working in tandem to achieve that end). 
federal government, while the FCC manages "non-federal and commercial uses." ${ }^{332}$ Each agency maintains a spectrum use database that tracks licenses and other such uses. ${ }^{333}$ The FCC has also deployed a spectrum "dashboard" that "provides a public means of reviewing how spectrum bands are allocated and for what uses, and who holds licenses and in what areas." ${ }_{334}$ However, since thousands of spectrum bands exist and since thousands of licenses have been doled out, ${ }^{335}$ the scope of spectrum usage is vast and often difficult to monitor.

The federal government, for example, is one of the most intensive users of spectrum. ${ }^{336}$ According to a 2008 report issued by the NTIA, "[s]ixty-nine Federal agencies and departments further their missions by using radio frequency spectrum for communications, navigation, broadcasting and other purposes." ${ }^{337}$ These agencies "use over [forty] specific radio services and their frequency assignments are recorded in the Government Master File maintained by NTIA." ${ }^{338}$ However, monitoring the myriad agencies using spectrum has proven to be unwieldy for the NTIA. By its own admission, "the current spectrum management system at times lacks the flexibility to rapidly accommodate new operational requirements and innovative technologies." ${ }^{339}$ As a result, the federal government is a very inefficient user of its spectrum. Indeed, several surveys suggest that, at any one time, a significant amount of government-owned spectrum is unused or underused. ${ }^{340}$ Other studies that examined public uses of spectrum confirmed that this resource is generally underused by government. ${ }^{341}$

332 See Spectrum Reform,CCIANET.ORG, http://www.ccianet.org/Spectrum-Reform (last visited Jan. 1, 2011).

333 For example, the FCC maintains several Frequency Assignment Data Bases, available at http://www.fcc.gov/oet/info/database/Welcome.html (last updated Aug. 4, 2010).

334 See About the Spectrum Dashboard, REBOoT.FCC.GOV, http://reboot.fcc.gov/reform/systems/spectrum-dashboard/about (last visited Jan. 1, 2011 ).

335 See, e.g., Patricia Fusco, FCC Closes Spectrum License Auction, INTERNETNEWS.COM (May 9, 2000), http://www.internetnews.com/xSP/article.php/357581/FCC-ClosesSpectrum-License-Auction.htm.

336 End of Spectrum Scarcity, supra note 309, at 3 (estimating "the federal government exclusively controls over 13 percent of all allocated spectrum bands and has primary access to shared bands comprising 56 percent of all other bands" and "federal government exclusive and shared bands account for 64 percent of all allocations below $3.1 \mathrm{GHz}$ ").

337 Carlos M. Gutierrez \& Meredith A. Baker, U.S. Dep'T of Com., Spectrum Management for the 21 st Century: The President's Spectrum Policy Initiative 3 (2008), available

http://www.ntia.doc.gov/reports/2008/FederalStrategicSpectrumPlan2008.pdf.

338 Id.

339 Id.

340 End of Spectrum Scarcity, supra note 309, at 3 (citing government documents obtained by the New America Foundation and studies conducted by Mark McHenry).

341 End of Spectrum Scarcity, supra note 309, at 3 (citing NEW AMERICA FOUNDATION, 
Most agree that additional information is needed in order to better understand how this resource is being used and to identify fallow or underutilized bands that could be reallocated. ${ }^{342}$ To this end, two bills were introduced in Congress in 2009 that would require a federal spectrum inventory, the results of which would be made publicly available via a web portal. ${ }^{343}$ The wireless industry ${ }^{344}$ and a number of other stakeholders have endorsed the idea of an inventory. ${ }^{345}$ While there is some disagreement among stakeholders regarding whether a spectrum inventory should result in reallocation or not, most agree that a comprehensive and rapid review of current spectrum usage is a necessary condition precedent to adjusting allocation policies that support further wireless broadband deployment. ${ }^{346}$

Dupont Circle Spectrum Utilization During Peak Hours: a Collaborative Effort of The New America Foundation and The Shared SpeCtrum Company (2003), available at http://www.newamerica.net/files/archive/Doc_File_183_1.pdf); Spectrum Occupancy Measurements, SHARED - SPECTRUM Co., http://www.sharedspectrum.com/measurements (last visited Jan. 1, 2011).

342 See, e.g., Joelle Tessler, Government Working on Wireless Spectrum Inventory, $\begin{array}{lllll}\text { MSNBC.COM (July } & 14, & 2010, & 5: 44 & \text { PM), }\end{array}$ http://www.msnbc.msn.com/id/38249699/ns/technology_and_science-tech_and_gadgets/ (discussing the reasons behind the forthcoming government inventory of the entire spectrum, including the identification and reallocation of certain bands for the "cutting-edge $4 \mathrm{G}$ services now being rolled out by the big mobile carriers").

343 The Radio Spectrum Inventory Act of 2009 (S. 649 ) was introduced in March 2009 and calls on the NTIA and FCC to compile a report that "includes an inventory of each radio spectrum band, from 300 Megahertz to 3.5 Gigahertz, managed by each such agency." The Radio Spectrum Inventory Act, S. 649, 111 th Cong. $\$ 2$ (2009). The Radio Spectrum Inventory Act of 2009 (H.R. 3125) was introduced in July 2009 and calls on the NTIA and FCC to "create an inventory of each radio spectrum band of frequencies used in the United States Table of Frequency Allocations, from 225 megahertz to 10 gigahertz." Radio Spectrum Inventory Act of 2009 , H.R. 3125, 11 th Cong. $\$ 2$ (2009) The House passed this version of the bill in April 2010. See John Eggerton, House Passes Spectrum Inventory Bill, Broad. \& CABle (Apr. 14, 2010, 5:15 PM), http://www.broadcastingcable.com/article/451482-

House_Passes_Spectrum_Inventory_Bill.php.

344 See, e.g., Press Release, CTIA - The Wireless Ass'n, CTIA-The Wireless Association Applauds Introduction of Radio Spectrum Inventory Act (March 20, 2009) available at http://www.ctia.org/media/press/body.cfm/PRID/1803.

345 End of Spectrum Scarcity, supra note 309, at 5; see also Richard Whitt, Taking Stock of the Nation's Airwaves, Google PuB. PoL'Y Blog (May 4, 2009, 10:55 AM), http://googlepublicpolicy.blogspot.com/2009/05/taking-stock-of-nations-airwaves.html (announcing Google's support of a spectrum inventory); Elise Ackerman, Google and Others Urge Inventory of National Airwaves, PHYSORG, May 6, 2009, http://www.physorg.com/news $160850607 . h t m l$ (noting that "In a rare show of unity over national communications policy, Google, the wireless industry and consumer advocates have come together to support a bill that would require the federal government to take a complete inventory of the national airwaves to determine what spectrum is being used, how it is being used and who is using it.").

346 Overview of the National Broadband Plan, 18 Commlaw Conspectus 517, 518 
C. Develop \& Implement Clear Policy Mechanisms for Making Additional Spectrum Available in a Timely Manner: Reallocation

Another critical step towards making additional spectrum available in a timely manner is the development and implementation of clear policy mechanisms for reallocating underused and unused portions of the airwaves.

Reallocating spectrum is a complicated and time-intensive process that requires, among other things, identifying contiguous bands that would support a certain type of wireless deployment (e.g., broadband), clearing that spectrum, which entails relocating incumbent users, and auctioning the spectrum. ${ }^{347}$ This process typically takes several years to complete, and, in some cases, can take as long as a decade. ${ }^{348}$ For example, it took approximately 13 years for the spectrum in the $700 \mathrm{MHz}$ proceeding to be cleared and made available for auction. ${ }^{349}$ As previously discussed, a portion of this spectrum has yet to be auctioned. ${ }^{350}$

The mechanics of reallocating spectrum vary from proceeding to proceeding. In general, most reallocations involve multiple technical inquiries and rulemaking proceedings in order to assure that incumbent users are relocated to spectrum bands that will support their uses and that the spectrum is able to support the new deployments that it is being cleared to support. ${ }^{351}$ For example,

(2010).

347 End of Spectrum Scarcity, supra note 309, at 7.

348 FCC Presentation, supra note 51, at slide 16 (estimating that it takes approximately 613 years to make spectrum available); NATIONAL BROADBAND PlAN, supra note 11, at 79 (providing several additional examples of how long it takes to clear spectrum).

349 The process began with provisions regarding digital television in the Balanced Budget Act of 1997. See Balanced Budget Act of 1997, Pub. L. No. 105-33, 111 Stat. $251 \S 3004$ (1997) (codified as amended at 47 U.S.C. $\$ 337$ (2006); see also LENNARD G. KRUGER, CONG. Research Serv., RL 31260, Digital Television: AN OVERVIEW, available at $\mathrm{http}: / / \mathrm{www}$.usembassy.it/pdf/other/RL31260.pdf (providing a comprehensive discussion of the digital TV transition, which freed up the spectrum available in the $700 \mathrm{MHz}$ auction)

350 See, Jonathan B. BaKer \& PaUl de Sa, Fed Commc'ns Comm'N, The Year IN ECONOMics At The FCC: A National Plan For Broadband (Oct. 13, 2010) (As of October 2010, the FCC has yet to hold an auction but has plans to do so).

${ }^{351}$ In re Service Rules for the 698-746, 747-762 and 777-792 MHz Bands; Revision of the Commission's Rules to Ensure Compatibility with Enhanced 911 Emergency Calling Systems; Section 68.4(a) of the Commission's Rules Governing Hearing Aid-Compatible Telephones; Biennial Regulatory Review - Amendment of Parts 1, 22, 24, 27, and 90 to Streamline and Harmonize Various Rules Affecting Wireless Radio Services; Former Nextel Communications, Inc. Upper $700 \mathrm{MHz}$ Guard Band Licenses and Revisions to Part 27 of the Commission's Rules; Implementing a Nationwide, Broadband, Interoperable Public Safety Network in the $700 \mathrm{MHz}$ Band; Development of Operational, Technical and Spectrum Requirements for Meeting Federal, State and Local Public Safety Communications Requirements Through the Year 2010; Declaratory Ruling on Reporting Requirement Under Commission's Part 1 Anti-Collusion Rule, Second Report and Order, 22 F.C.C.R. 15289, 9 | 
during the broadband PCS proceeding, the FCC issued new licenses under flexible use rules while requiring incumbents to clear, relocate or retune to alternative bands by a specified date. ${ }^{352}$ Ahead of the first AWS auction in 2006, which reallocated a large swath of government-owned spectrum for broadband purposes, ${ }^{353}$ the FCC required the relocation of Broadband Radio Service and Fixed Microwave Service incumbents from the $2.1 \mathrm{GHz}$ band, and set forth a comprehensive cost-sharing framework for such relocations. ${ }^{354}$ In addition, the FCC adjusted the terms and conditions associated with these licenses in order to "give licensees more time to build out service in a spectrum band where equipment did not yet exist." 355 Yet despite these adjustments and the creation of a relocation fund to "provide a mechanism whereby federal agencies can recover the costs of moving from one spectrum band to another," carriers encountered a number of problems during their attempts to deploy network infrastructure. ${ }^{356}$ Foremost among these obstacles were the delays associated with clearing portions of the auctioned spectrum. ${ }^{357}$ These delays pushed back scheduled network deployments for several carriers. ${ }^{358}$

Other considerations may complicate the reallocation process. For example, in the $700 \mathrm{MHz}$ reallocation process, television broadcasters were required to relocate their services in order to free up spectrum for commercial wireless services and to make available digital television services. ${ }^{359}$ The original target date for completing this transition was $2006 .{ }^{360}$ However, this date was moved back several times for a variety of reasons, ${ }^{361}$ including a lack of public awareness regarding the need for acquiring a digital receiver that would be necessary

432-43 at 15443-46 (July 31, 2007); see SPTF REPORT, supra note 170, at 50-51 (describing the various methods for spectrum transitions with particular attention to incumbent transitions).

352 SPTF REPORT, supra note 170 , at 48-51.

353 See Linda K. Moore, Cong. Research Serv., RL 31764, Spectrum Management: AUCTIONS, 9-10 (2008) [hereinafter SPECTRUM MANAGEMENT: AUCTIONS].

354 AWS-1 Rules, supra note 239.

355 MOMENTUM BUILDING, supra note 238, at 12.

356 Linda K. Moore, Cong. Research Serv., RL 31764, Spectrum Management: Auctions 9 (2008) (discussing the genesis of the Commercial Spectrum Enhancement Act, Title II of P.L. 108-494.

357 See Winter, supra note 329 (discussing the difficulties that T-Mobile faced when trying to clear spectrum for their $3 \mathrm{G}$ network).

358 See, e.g., id. (noting that some carriers, including T-Mobile, were forced to delay the deployment of $3 \mathrm{G}$ services in several markets due to such delays).

359 Kruger, supra note 349 , at 2-3; Auction of $700 \mathrm{MHz}$ Band Licenses Scheduled for January 16, 2008; Comment Sought on Competitive Bidding Procedures for Auction 73, Public Notice, 22 F.C.C.R. 15004, ๆ 1-4 (Aug, 17, 2007) (introducing and describing the $700 \mathrm{MHz}$ auction).

$360 \mathrm{Id}$. at 3.

$361 \mathrm{Id}$. 
to convert new digital television signals on older televisions. ${ }^{362}$

Ensuring that reallocations are successfully completed in a timely manner is essential given the high costs associated with acquiring the spectrum and deploying new network infrastructure. ${ }^{363}$ The inherently scarce nature of spectrum has resulted in this resource being viewed as a valuable commodity. ${ }^{364}$ As such, aggregate bidding in major spectrum auctions often reaches the multibillion dollar level. ${ }^{365}$ Conversely, the opportunity costs associated with failing to successfully auction off spectrum capable of supporting broadband deployment are potentially enormous. For example, several studies suggest that the opportunity costs associated with failing to auction off spectrum in the D-block of the $700 \mathrm{MHz}$ band range from $\$ 1-2$ billion. ${ }^{366}$

Given the complexity and high stakes of reallocation, some have urged for a spectrum inventory to result in a more open approach to spectrum allocation and use. ${ }^{367}$ For example, some stakeholders have advocated in favor of mandating the sharing of underutilized spectrum between the incumbent and other providers. ${ }^{368}$ In particular, proposals to "overlay" or "underlay" multiple uses of spectrum have been put forward as a way to realize the full potential of certain spectrum bands. ${ }^{369}$ These proposals rest partly on the assumption that

362 See, e.g., Chloe Albanesius, House Approves DTV Transition Delay, PC MAG. (Feb. 4, 2009), http://www.pcmag.com/article2/0,2817,2340416,00.asp (reporting on Congress's decision to push the DTV transition date back from Feb. 17 to June 12 in order to increase public awareness of the transition).

363 Id.

364 Wireless Craze, supra note 166, at 566.

365 See Pennsylvania State University, Center for the Study of Auctions, Procurements and Competition Policy, FCC Spectrum Auction Data, http://capcp.psu.edu/FCC ( providing data on each of the 82 spectrum auctions to date). According to this page, the seven auctions that resulted in multi-billion dollar aggregate bidding involved spectrum capable of supporting broadband-type services (e.g., PCS, 3G and 4G, etc.).

366 See Robert W. Hahn et al., The Static and Dynamic Inefficiency of Abandoning Unrestricted Auctions for Spectrum: A Critique of Professor Wilkie's Analysis of the M2Z Proposal 22 (Criterion Economics LLC, Working Paper, 2008), available at http://papers.ssm.com/sol3/papers.cfm?abstract_id=1229782; Value of Unencumbered AWS-III Spectrum, supra note 268. Cf. Simon Wilkie, M2z Networks, Spectrum AuC-

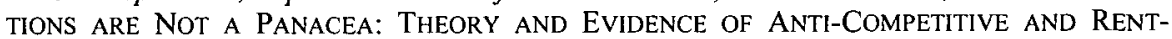
SEEKING BEHAVIOR IN FCC RULEMAKINGS AND AUCTION DESIGN (2007)(arguing in favor of a proposal to assign rather than auction off the D-block of spectrum in the $700 \mathrm{MHz}$ band for use by M2Z Networks).

367 Joelle Tessler, Government Working on Wireless Spectrum Inventory, MSNBC.COM (July 14, 2010, 5:44 PM), http://www.msnbc.msn.com/id/38249699.

368 In its spectrum PN, the FCC asked for comments on the viability of this potential arrangement. FCC Spectrum PN, supra note 281, at 12036.

369 End of Spectrum Scarcity, supra note 309, at 7-8 (distinguishing underutilized spectrum is that which is shared between licensees in certain bands from overlaying spectrum, which involves assigning to a new licensee, band that was originally vacant and used to separate spectrum users). 
commercial mobile providers are inefficient users of spectrum and that alternate providers could leverage underused portions of a network to provide service ${ }^{370}$ However, several studies have found that wireless service providers are in fact very efficient users of their spectrum. ${ }^{371}$ Unlike their international counterparts, commercial wireless network owners in the United States have been forced to develop innovative approaches for making do with less spectrum assets. ${ }^{372}$ In 2009, one analyst estimated that U.S. wireless carriers served three times as many subscribers per $\mathrm{MHz}$ of spectrum than carriers in Britain and twice as many as carriers in Japan. ${ }^{373}$ An approach that gives preference to mandated sharing arrangements over the reallocation of underused spectrum could reduce an incumbent's incentive to innovate by replacing organic experimentation with artificial policy prescriptions.

A more robust reallocation policy could strengthen incentives for licensees to maximize utilization of their particular portion of the airwaves. ${ }^{374}$ Even though commercial mobile service providers are efficient users of spectrum, a number of other private-sector licensees have been accused of under-using spectrum resources. ${ }^{375}$ For example, some have argued that spectrum allocated for broadcast television content is inefficiently used ${ }^{376}$ and potentially impeding billions of dollars in consumer welfare gains. ${ }^{377}$ Indeed, by some estimates, upwards of $174 \mathrm{MHz}$ of spectrum is underutilized in major markets across the

\footnotetext{
370 Marguerite Reardon, Rethinking the Wireless Spectrum Crisis, CNET NEws (May 25, 2010, 4:00 AM), http://news.cnet.com/8301-30686_3-20005831-266.html.

371 See John T. MCDONALd, ILLINOIS INST. OF TECH., A SURVEY OF SPECTRUM UTILIZATION IN CHICAGO 2007), available at http://www.ece.iit.edu/ wemi/publications/spectrum.pdf; see also generally JOHN T. MCDonald \& Dennis A. Roberson, Illinois Inst. Of TeCH., SPECTRUM OCCuPANCy EsTIMATION IN WIRELESS CHANNELS WITH ASYMMETRIC POWER TraNSMITTERS (2007), available at http://www.wemi.ece.iit.edu/publications/crowncom.pdf (describing the process by which cognitive radio systems scan the spectrum to determine where there are new areas of spectra that can be utilized).

372 CUSTOMER-CENTRIC FRAMEWORK, supra note 310 , at 9.

373 Id. at 21 .

374 Id. at $20-21$.

375 Reardon, Rethinking the Wireless Spectrum Crisis, supra note 370.

376 Thomas Hazlett has noted that FCC rules regarding broadcast spectrum limit the ability of licensees to "underutilize spectrum-saving techniques." See Thomas W. Hazlett, Optimal Abolition of FCC Spectrum Allocation, 22 J. ECON. PERSP. 103, 106 (2008).

377 One commentator has observed that "the spectrum dedicated to UHF TV broadcasting has less value as a medium for transmitting TV signals than it does for an array of other uses," including commercial wireless services. See Philip J. Weiser, The Untapped Promise of Wireless Spectrum 20, Brookings Institution Hamilton Project Discussion Paper 08-8 (July 2008), [hereinafter Untapped Promise], available at http://www.brookings.edu/ /media/Files/rc/papers/2008/07_wireless_weiser/07_wireless_w eiser.pdf.
} 
country. ${ }^{378}$ Moreover, it would appear that the evolving television business model militates against generous spectrum arrangements for broadcasters since "the vast majority of programming from over-the-air broadcasters is viewed on subscription services such as cable and satellite," which has resulted in a large amount of spectrum being underutilized. ${ }^{379}$ The FCC has observed that the number of people who receive over-the-air television has decreased by 56 percent over the last decade. ${ }^{380}$ By one estimate, reallocating this spectrum for wireless broadband purposes could result in a consumer surplus exceeding $\$ 1$ trillion. ${ }^{381}$ Others have postulated that the benefits associated with the reallocation of underutilized spectrum by television broadcasters, such as the availability of additional prime spectrum for auction, vastly outweigh the economic and social costs of reclaiming these swaths of the airwaves (e.g., a decrease in free programming available via the traditional over-the-air distribution model). ${ }^{382}$ These swaths of spectrum are especially valuable given their potential robustness for wireless broadband purposes. ${ }^{383}$

The Obama administration, ${ }^{384}$ the $\mathrm{FCC},{ }^{385}$ and many other prominent stake-

378 See Ex Parte Letter from CTIA - The Wireless Association, to Chairman Julius Genachowski, Comm'r Michael J. Copps, \& Comm'r Robert M. McDowell, Fed. Commc'ns Comm. (July 9, 2009), available at http://files.ctia.org/pdf/filings/2009_Wireless_Economic_Contributions.Letter.Final.pdf.

379 See Coleman Bazelon, THE Brattle Group, THE NeEd for additional SPECTRUM FOR Wireless BROADBAND: THE ECONOMIC BENEFITS AND COSTS OF REALlocations 1 (2009), [hereinafter NEED FOR ADDITIONAL SPECTRUM], available at www.brattle.com/documents/uploadlibrary/upload809.pdf

380 See Blair Levin, Exec. Dir., Omnibus Broadband Initiative, Fed. Comm'cns Comm'n, Remains at The Progress \& Frecdom Foundation Congressional Seminar: Let's Make a Deal: Broadcasters, Mobile Broadband, and a Market in Spectrum (Dec. 1, 2009), in ProGRESS \& Freedom Found., Progress ON POINT No. 16.27, at 22 (2009).

381 Id. at 8.

382 See, e.g., Stuart Minor Benjamin, Roasting the Pig to Burn Down the House: A Modest Proposal, 7 J. ON Telecomm. \& High TECH. L. 95, $97-98$ (2009) [hereinafter Burn Down the House]. Benjamin writes that

The value of [broadcast] spectrum is enormous. The revenue generated by selling the spectrum would depend on auction prices, of course, but the estimated range is in the hundreds of billions of dollars. And because service providers could not capture all the value of the spectrum, the value to citizens - the consumer surplus created by the new services - would far exceed the auction revenue.

Id. See also Stuart Minor Benjamin, Evaluating the Federal Communications Commission's National Television Ownership Cap: What's Bad for Broadcasting Is Good for the Country, 46 WM. \& MARY L. REV. 439, 496 (2004) (outlining a way for government to subsidize continued access to free programming to consumers negatively impacted by the reallocation of broadcast spectrum).

383 See Spectrum Analysis: Options for Broadcast Spectrum, FCC OBI Technical Paper No. 3, June 2010, at 1 [hereinafter Spectrum Analysis].

384 Memorandum from Pres. Obama on the Wireless Broadband Revolution to the heads of Executive Departments and Agencies (June 28, 2010), [hereinafter Wireless Broadband 
holders have endorsed a plan that would encourage television broadcasters to "voluntarily clear spectrum through incentive auctions." 386 Under this approach, broadcasters would be able to make their spectrum resources available to wireless broadband innovators via an auction, the proceeds of which would be shared with the U.S. Treasury. ${ }^{387}$ In addition, broadcasters would be provided with additional spectrum resources in order to ensure that they are able to continue providing service and to ensure that the FCC continues to adhere to its commitment to competition, diversity, and localism. ${ }^{388}$ The goal of this approach is to bolster federal efforts to make a total of $500 \mathrm{MHz}$ of additional spectrum available to wireless broadband innovators over the next decade. ${ }^{389}$ The FCC has outlined several different scenarios and incentive auction structures in the hope of spurring broadcasters to voluntarily relinquish existing spectrum assets for auction. ${ }^{390}$ However, the voluntary aspect of this approach may prove to be an impossible barrier to overcome, as could the requirement that broadcasters share only a percentage of auction revenues with the U.S. Treasury. ${ }^{391}$ Moreover, even though there is a spectrum quid pro quo involved in each of the FCC's auction scenarios, many of the more viable approaches would require Congressional action to adjust FCC authority, which could slow the process. ${ }^{392}$

In sum, a robust policy that clearly defines the conditions under which spectrum bands will be reallocated could result in additional spectrum being made available to innovators that need it for new deployments. ${ }^{393}$ In addition, in order to satiate short-term demand for additional spectrum, an approach that favors reallocation over forced sharing, and one that strengthens incentives for

\footnotetext{
Revolution Memo], available at http://www.whitehouse.gov/the-press-office/presidentialmemorandum-unleashing-wireless-broadband-revolution.

385 Spectrum Analysis, supra note 383; NATIONAL BROADBAND PlaN, supra note 11, at 81-82.

386 NATIONAL BROADBAND PLAN, supra note 11, at 81.

387 Spectrum Analysis, supra note 383, at 24.

388 Id. at 25.

389 Wireless Broadband Revolution, supra note 387.

390 Spectrum Analysis, supra note 383, at 25-27.

391 Michael Grotticelli, Vague 'Voluntary Spectrum Auction Bill' introduced in House, Broadcast Engineering (Aug. 2, 2010, 8:00AM), http://broadcastengineering.com/news/voluntary-spectrum-auction-bill-introduced-

House/index.html.

392 Spectrum Analysis, supra note 383, at 25.

393 As opposed to implementing regulations that continue to encourage inefficient uses of spectrum even though those regulations might, on their face, be in the public interest. See, e.g., Burn Down the House, supra note 382, at 100 (arguing against regulations that would entrench broadcasters in their swaths of spectrum and in favor of regulations that would increase the costs associated with keeping the spectrum).
} 
maximizing utilization of existing spectrum resources, would provide innovators with sufficient certainty in their ability to experiment and innovate and the network level. ${ }^{394}$ Such certainty will encourage continued investment, which is critical to further deployment of necessary network infrastructure that can support more bandwidth-intensive uses. ${ }^{395}$

\section{Develop \& Implement Clear Policy Mechanisms for Making Additional Spectrum Available in a Timely Manner: Secondary Markets}

Secondary spectrum markets represent a valuable and efficient way of ensuring that "spectrum will migrate to more efficient uses." 396 Over the course of the $2000 \mathrm{~s}$, the FCC developed a secondary market policy for spectrum that supports a range of leasing arrangements, ${ }^{397}$ including "wholesale access to carriers' infrastructure and spectrum." ${ }^{398}$ Other reforms included a concerted effort to "remove regulatory barriers" and streamline administrative processes for approving license transfers and assignments. ${ }^{399}$ The FCC also recently clarified the rights and responsibilities of incumbent licensees that wish to engage in secondary spectrum market transactions. ${ }^{400}$ For example, incumbent licensees have control over establishing technical parameters of the types of devices that can be used in their "private commons" and are responsible for preventing harmful interference beyond their band. ${ }^{401}$

\footnotetext{
394 See, e.g. Ian Grant, Spectrum Reallocation is Key to Digital Britain, COMPUTER WEEKLY, $\quad$ Oct. $22,2009,2$ available at http://www.computerweekly.com/Articles/2009/10/22/23827i ispectrum-redlocátiôni-is-kcyto-digital-britain.htm (noting that spectrum reallocation is essential to realizing Britain's goal of "guaranteed universal access to a minimum 2Mbps broadband connection by 2012.")

395 NET NEUTRALITY, INVESTMENT \& JOBS, supra note 5, at 20-23.

396 See John W. Mayo \& Scott Wallsten, Georgetown Ctr. For Bus. \& Pub. Pol'y, EnABling EfFicient Wireless COMMUNiCATIONS: ThE ROLE OF SECONDARY SPECTRUm MARKETS 2 (2009), [hereinafter ROLE OF SECONDARY SPECTRUM MARKETS]. available at http://www.gcbpp.org/files/Academic_Papers/EnablingWirelessCommunicationsJuly2009.p df.

397 Id. at $9-11$.

398 Id. at 13. Lessees are known as Mobile Virtual Network Operators (MVNOs). Examples of MVNOs include Tracfone. Id.

399 See Secondary Markets Initiative, FED. CoMmC'NS COMM'N, WIRELESS TELECOMm. BUREAU, http://wireless.fcc.gov/licensing/index.htm?job=secondary_markets (last updated Aug. 13, 2010).

400 Spectrum Bridge, InC., Analysis of FCC Secondary Spectrum Markets PosiTIONS, POLICIES AND COMMENTS 1 (2008), available at http://spectrumbridge.com/web/images/whitepapers/analysisoffccsecondaryspectrummarket s.pdf.

401 See id. at 7.
} 
Secondary spectrum markets are beginning to emerge, but face two key barriers to further development and more robust use. ${ }^{402}$ First, even though the FCC has implemented policies to streamline the administrative aspects of secondary market transactions, ${ }^{403}$ a number of information problems exist. For example, the FCC's database that tracks spectrum licenses, the Universal Licensing System, has been criticized as being frustratingly opaque. ${ }^{404}$ As a result, parties interested in entering into a lease agreement or other such spectrum arrangements may find it difficult to identify suitable partners. ${ }^{405}$ To overcome this impediment, several innovative approaches have been proposed to enhance the quality of information provided to interested parties. For example, Spectrum Bridge has launched an online spectrum trading site to expand the secondary spectrum market by providing more consumer-friendly information regarding available spectrum licenses. ${ }^{406}$ This company also maintains a database of unlicensed spectrum, including white spaces. ${ }^{407}$ In addition, the FCC's Spectrum Dashboard, and a commitment to "implement ongoing improvement to the database," are promising first steps toward lowering current informational barriers. ${ }^{408}$

Second, the range of allowed secondary market transactions is limited. Leasing and transfers are allowed so long as lessees adhere to the same set of usage rules as the incumbent lessee. ${ }^{409}$ Secondary markets do not allow for reallocation. ${ }^{410}$ For example, the current framework does not allow a broadcaster to sell their licenses to interested commercial mobile service providers ${ }^{411}$ even though the estimated market value of "broadcasters' spectrum if it was available for wireless broadband [is] about $\$ 62$ billion." ${ }^{412}$ These types of limitations skew

402 Untapped Promise, supra note 377.

403 NATIONAL BROADBAND PLAN, supra note 11, at 5.

404 Role OF SECONDARY SPECTRUM MARKETS, supra note 396, at 18-19.

405 Untapped Promise, supra note 377, at 12.

406 See Marin Perez, Spectrum Bridge Launches Online Secondary Market, INFO. WEEK

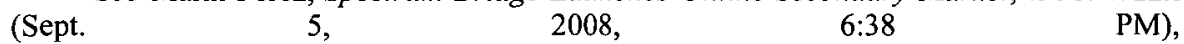
http://www.informationweek.com/news/telecom/regulation/showArticle.jhtml?articleID=21 0500380 .

407 See SpecEx, TV White Spaces, UDIA, and uAccess - Smart Wireless Access, SPECTRUM BRIDGE, http://spectrumbridge.com/products-services.aspx (last visited Jan. 1, 2011 ).

408 NATIONAL BROADBAND PLAN, supra note 11 , at 80.

409 In re Promoting Efficient Use of Spectrum Through Elimination of Barriers to the Development of Secondary Markets, Second Report and Order, 19 F.C.C.R. 17503, ๆף 100108 (July 8, 2004).

410 See, e.g. Thomas W. Hazlett, Property Rights and Wireless License Values, 51 J.L. \& ECON. 563, 566 n.5 (2008).

411 Id. at 566-67 (noting that the current approach "allows trading of existing rights rather than reallocation of spectrum [say, using TV band frequencies for a new wireless broadband service]"').

412 NeEd For AdDITIONAL SPECTRUM, supra note 379, at 2. 
the economic incentives that bolster the efficient allocation of resources in most secondary markets and could be discouraging more robust utilization of and maximally efficient transfers via secondary spectrum markets. ${ }^{413}$ Allowing a broader range of secondary market transactions, including reallocations, might enhance the view among spectrum owners that these types of transactions are "worth the effort."

\section{E. Bolster Policies to Ensure Maximum Utilization of Existing Spectrum Assets}

Since additional spectrum is unlikely to be made available in the immediate near-term, ${ }^{415}$ wireless network operators will require wide latitude to maximize the use of their existing spectrum assets. This section analyzes and assesses a critical component of this strategy, network management.

The spectrum used by wireless carriers is a shared resource, which means that increases in traffic on a network at any one time can cause congestion. ${ }^{416}$ Even though wireless service providers are upgrading their networks to provide higher throughput data speeds, ${ }^{417}$ robust consumer demand for more interactive and real-time wireless services and applications (e.g., streaming radio and video) is beginning to challenge existing traffic management techniques. ${ }^{418}$

As previously discussed, wireless data traffic has increased exponentially

413 As one commentator posits, "The benefits of this [approach] go far beyond efficiency in spectrum use. A major economic benefit is that anywhere suppliers of communications service are overcharging customers, entrants can get the spectrum they need to build new capacity, driving down the prices consumers have to pay for service." See Bruce M. Owen, A Fresh Start in Communications Policy: Two Modest Reforms, in NEw DiREcTIONS IN Communications Policy 2 (R. May ed., 2008).

414 Untapped Promise, supra note 377 , at 12.

415 As previously discussed, CTIA estimates that only $40 \mathrm{MHz}$ of spectrum is expected to be made available in the short-term. See discussion supra note 341.

416 See Roger Entner, Considerations Around Wireless Net Neutrality: The Few Vs. the Many, NIELSEN WIRE BLOG (Oct. http://blog.nielsen.com/nielsenwire/online_mobile/considerations-around-wireless-netneutrality-the-few-vs-the-many/ [hereinafter Considerations Around Wireless Net Neutralityl (noting that wireless network's are increasingly challenged "when we move from bursty traffic to streaming."); see also Michael J. Santorelli, Rationalizing the Municipal Broadband Debate, 3 I/S: J.L. \& POL'Y FOR INFO. SOC'Y 43, 54 (2007) (comparing the various modes of delivering broadband and noting that shared deliver mediums-Wi-Fi, cable broadband, and cellular 3G, among others-"can slow down with an increase in the number of users on an immediate network").

417 See Martin Moylan, Wireless Companies to Roll Out Higher-Speed Data Service,

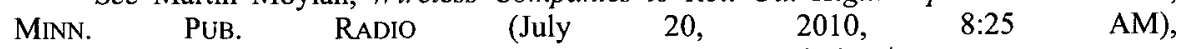
http://minnesota.publicradio.org/display/web/2010/07/20/4g-wireless/.

418 Considerations Around Wireless Net Neutrality, supra note 416 (noting that wireless network's are increasingly challenged "when we move from bursty traffic to streaming."). 
over the last few years as more consumers purchase smartphones and utilize an array of broadband-enabled applications on their handsets. ${ }^{419}$ The variation in the amount of bandwidth consumed by voice calls as compared to more advanced uses (e.g., watching video on a mobile device) is extreme. For example, one study has estimated that "a voice user with a 1,000-minute plan can consume about 100 megabytes of voice data in a month. However, a data user can consume this much data watching just 15 minutes of YouTube." ${ }^{\prime 20}$ Additional examples of the data speeds required by new wireless services and of new usage patterns generally provide insight into the unique challenges facing network managers.

Pandora, a streaming music service, is increasingly popular on smartphones. ${ }^{421}$ To date, some 13 million accounts have been created via mobile handsets. ${ }^{422}$ This type of application "typically uses about $40 \mathrm{~KB} / \mathrm{s}$ and can support around 90 concurrent users (a theoretical best case scenario of 3.6 $\mathrm{MB} / \mathrm{s}$ divided by $40 \mathrm{~KB} / \mathrm{s}$ ) in a cell sector." ${ }^{423}$ Most cell sectors, however, support more than 90 subscribers. ${ }^{424}$

Mobile video continues to gain in popularity among consumers. ${ }^{425}$ For example, uploads to YouTube continue to increase at a rapid pace. In the first half of 2009, YouTube reported a 1,700 percent increase in mobile uploads to its Web site. ${ }^{426}$ Slingbox, another popular streaming video application that allows a user to watch television episodes on their handset, uses approximately

419 See Suzanne Choney, Is 2010 the Year of Wireless Congestion?, MSNBC.COM (Jan. 4, 2010, 3:58 PM), http://www.msnbc.msn.com/id/34634571/ns/technology_and_sciencetech_and_gadgets/.

$42 \overline{0}$ See Rysavy Research, Wireless E-MAIL EFFICIENCY AsSESSMENT 3 (2009), available at www.rysavy.com/Articles/Rysavy_Wireless_EMail.pdf.

421 See Paul Bonanos, Pandora: $24 \%$ of Our Users Signed Up on a Mobile Phone, GIGAOM.COM (Nov. 19, 2009, 4:54 PM), http:/gigaom.com/2009/11/19/pandora-24-of-ourusers-signed-up-on-a-mobile-phone/.

422 Id.

423 Considerations Around Wireless Net Neutrality, supra note 416 (noting the size of a cell sector varies depending on the given geographic area and the number of subscribers in the immediate area - "How big is a cell sector? Anywhere from the size of the city block that houses Madison Square Garden in Manhattan, to the size of Capitol Hill in Washington DC to several square miles of corn fields in rural Nebraska.").

424 Id.

425 Nielsen estimated that mobile video penetration was approximately seven percent in mid-2009 and that it grew by 70 percent between 2008 and 2009. See Nic Covey, The State of Mobile Video: Promise vs. Progress, NIELSEN WIRE BLOG (Sept. 23, 2009), http://blog.nielsen.com/nielsenwire/consumer/the-state-of-mobile-video-promise-vsprogress/.

426 See Mobile Uploads to YouTube Increase Exponentially, YouTUBE BLoG (June 25, 2009), http://youtube-global.blogspot.com/2009/06/mobile-uploads-to-youtubeincrease_5122.html. 
$384 \mathrm{~KB} / \mathrm{s}^{427}$ If a particular cell sector provides for data throughput of 3.8 $\mathrm{MB} / \mathrm{s}$, then nine subscribers simultaneously watching TV via their Slingbox application would dominate that given sector. ${ }^{428}$

An increase in the use of mobile banking services has been linked to an increase in smartphone sales and to the deployment of advanced data networks. ${ }^{429}$ These types of applications require a seamless user experience, which is enabled by robust connectivity to the Internet. ${ }^{430}$

The next generation of mobile applications is increasingly providing realtime services (e.g., telemedicine tools and smart grid applications). ${ }^{431}$ An application available for use with the Android OS allows for GPS-enabled navigation services, including turn-by-turn directions, automatic rerouting, and live traffic updates. ${ }^{432}$

Many mobile devices, including smartphones and netbooks, will leverage cloud computing services to deliver remotely stored content. ${ }^{433}$ For example, Google's Chrome Operating System, which will initially run on netbooks, is "designed to start most data in the cloud with very little local storage." ${ }^{434}$ Under this model, data that is typically stored on a mobile device's hard-drive will instead be accessible via a wireless broadband connection. ${ }^{435}$

Increased mobile data usage also raises security risks for individual endusers and the core network. In recent years, several pernicious attacks on individual users have led to personal e-mail accounts being infiltrated. ${ }^{436}$ In addi-

427 Cf. Considerations Around Wireless Net Neutrality, supra note 416.

428 Id.

429 See Press Release, ComScore, Demand for Mobile Financial Services Poised to Grow with Increased Penetration of Smartphones and 3G Service (July 9, 2009), available at http://www.comscore.com/Press_Events/Press_Releases/2009/7/Demand_for_Mobile_Fina ncial_Services_Poised_to_Grow_with_Increased_Penetration_of_Smartphones_and_3G_Se rvice.

430 Id.

43I See Nadi Kaonga, In Search of Mobile Telemedicine Platform: A Few Open Source Applications, CNET NEws (Apr. 26, 2010), http://mobileactive.org/search-mobiletelemedicine-platform-review-open-source-applications; see also Marguerite Reardon, $T$ Mobile Goes for Smart Grids, CNET NEws (Apr. 23, 2009, 3:43 PM), http://news.cnet.com/8301-1035 3-10226418-94.html.

432 See Announcing Google Maps Navigation for Android 2.0, OfFICIAL Google BLOG (Oct. 28, 2009, 7:01 AM), http://googleblog.blogspot.com/2009/10/announcing-googlemaps-navigation-for.html.

433 See Mobile Cloud Computing Subscribers to Total Nearly One Billion by 2014, ABI RESEARCH (Sept. 4, 2009), http://www.abiresearch.com/press/1484Mobile+Cloud+Computing+Subscribers+to+Total+Nearly+One+Billion+by+2014.

434 See Tom Krazit, Google Has Its Own Plan for Netbooks, CNET NEws (Nov. 19 , 2009, 2:30 PM), http://news.cnet.com/8301-30684_3-10401919-265.html.

435 Tim Anderson, What is Cloud Computing?, GuARDIAN (June 21, 2010, 9:44 AM), http://www.guardian.co.uk/cloud-computing/what-is-cloud-computing.

436 Olga Kharif, Smartphones: A Bigger Target for Security Threats, BLoOMBERG BuSI- 
tion, one in five smartphone users have encountered a phishing scam, which is prevalent via wire-based broadband connections. ${ }^{437}$ Going forward, "as the mobile OS landscape changes, and with devices comprising a huge amount of memory and storing a host of sensitive data," smartphone devices will likely "increase as a popular target for" these types of attacks. ${ }^{438}$

In response to increased traffic on their networks, and in lieu of adding additional spectrum to networks given the looming spectrum gap, wireless service providers have employed a multifaceted approach to enhancing spectral efficiency, ${ }^{439}$ elements of which include:

Hardware. A number of hardware options are available to service providers that wish to maximize throughput speeds and enhance reliability. For example, a carrier could build additional cell sites or "split" these sites to bolster network performance by decreasing the size of cell sectors. ${ }^{440}$ However, such an approach will likely "reach a point of diminishing returns if the task consists solely of cell splitting an operator's existing frequencies." ${ }^{\prime 41}$ Other hardware options for bolstering spectrum include the use of femtocells, which extend the range of wireless service into homes and offices. ${ }^{442}$

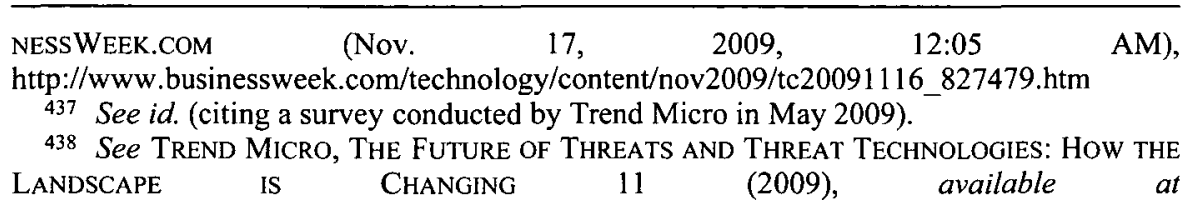
http://us.trendmicro.com/imperia/md/content/us/trendwatch/researchandanalysis/trend_micr o_2010_future_threat_report_final.pdf.

${ }_{439}$ See 3G A A., 3G̈PP TECHNOLOGY APPROACHES For MAXIMIZING Fragmented SPECTRUM ALLOCATIONS 18-19 (2009), http://www.3gamericas.org/documents/3GA Underutilized Spectrum_Final_7_23 092.pdf (discussing observations of one study that when "[c]onfronted with burgeoning demand, mobile network operators have three options for responding: build more cell sites; increase spectral efficiency of existing spectrum assets; and deploy more spectrum into their networks. Operators cannot pick and choose among these options, but must invoke all of them in the hunt for capacity."); In re A National Broadband for Our Future; International Comparison and Consumer Survey Requirements in the Broadband Data Improvement Act; Inquiry Concerning the Deployment of Advanced Telecommunications Capability to All Americans in a Reasonable and Timely Fashion, and Possible Steps to Accelerate Such Deployment Pursuant to Section 706 of the Telecommunications Act of 1996, Comments of CTIA - The Wireless Association, GN Docket No. 0951; GN Docket No. 09-47; GN Docket No. 09-137, at 14 (Sept. 23, 2010) (accessible via FCC Electronic Comment Filing System); In re Preserving the Open Internet Broadband Industry Practices, Reply Comments of AT\&T, Inc., GN Docket No. 09-191, WC Docket No 07-52, at 77-79 (Apr. 26, 2010) (accessible via FCC Electronic Comment Filing System).

440 BRoAdBand Evolution To 4G, supra note 48, at 19.

441 BROADBAND EVOLUTION TO 4G, supra note 48, at 19.

442 See, e.g., $\quad A T \& T \quad 3 G \quad$ MicroCell, AT\&T, http://www.wireless.att.com/learn/why/3gmicrocell/ (last visited Jan. 1, 2011) ("AT\&T 3G MicroCell acts like a mini cellular tower in your home or small business environment. It 
Software. In addition to the hardware that comprises the physical infrastructure of a wireless network, service providers have developed and implemented a range of software solutions for supporting more intensive data uses. ${ }^{443}$ Indeed, the shift towards next-generation wireless network capabilities will involve a number of software upgrades throughout the network, including at the base station level. ${ }^{444}$ For example, components of the Evolved EDGE standard for wireless networks require only software upgrades in order to increase peak data speeds by 100 percent and "[t]o avoid impacts on infrastructure by enabling improvements through a software upgrade." ${ }_{445}$ In addition, carriers are increasingly using subscriber management software to more efficiently track and manage data usage across networks. ${ }^{446}$

Usage policies. Nearly all wireless carriers provide subscribers with a variety of options for using wireless data. ${ }^{447}$ Different phones, data packages, and pricing plans provide customers with a variety of options for purchasing these

connects to AT\&T's network via your existing broadband Internet service (such as DSL or cable) and is designed to support up to four simultaneous users in a home or small business setting.").

${ }_{443}$ See, e.g., Why Is WiMAX Important for Mobile Broadband Wireless?, WIMAX, http://www.wimax.com/general/why-is-wimax-important-for-mobile-broadband-wireless (last visited Jan. 1, 2011) (discussing Verizon, Sprint, AT\&T, and Clearwire are carriers using software solutions to "produce higher-capacity broadband systems"); CiSCO SYS., MaXimizing Use of Mobile Data INFrastructure: THE IMPORTANCE OF SERVICE CONTROL IN MOBILE NETWORKS 1-6 (2005), available at http://www.cisco.com/en/US/prod/collateral/ps7045/ps6129/ps6257/ps6501/prod_white_pa per0900aecd80342822.pdf (explaining service providers' use of Cisco Systems service control technology "include the ability to analyze traffic usage, control bandwidth allocation . . , and secure theire network from malicious traffic as data services increase). See generally Huwaei - Software, HUAWEI, http://www.huawei.com/software.do (Jan. 1, 2011) (discussing Huawei Software services and products usage by " 426 operators in 138 countris" to enhance end-to-end operations); Telecordia - Innovation - Industry Leadership - Research Highlights, TELECORDIA, http://www.telecordia.com/innovation/industry/research.html (last visited Jan. 1, 2011) (demonstrating that through innovative software technologies, Telecordia provides solutions to the telecommunications industry).

444 See generally BROADBAND Evolution to 4G, supra note 48, at 5, 29-30, 55, 68, 87 (discussing the various software upgrades required for transitioning to $4 \mathrm{G}$ network capabilities).

445 Id. at 69.

446 See Olga Kharif, Managing the Wireless Data Deluge, BLOOMBERG BuSINESSWEEK.COM, (Dec. 23, 2009, 8:53 $\quad$ PM), http:/www.businessweek.com/technology/content/dec2009/tc20091223_992099.htm ("Research firm Infonetics expects the market for this type of software to grow from $\$ 145$ million in 2008 to nearly $\$ 800$ million by $2013 \ldots$. .").

447 See, e.g., LOSING THE FOREST, supra note 25, at 11-14 (describing the array of service plans available to consumers). 
services. For example, BlackBerry users typically have an option of purchasing unlimited data plans, whereas purchasers of wireless data cards for netbooks usually have a choice of plans allowing for different levels of data usage per month. ${ }^{448}$ This allows carriers to have some certainty in the amount of traffic it can expect flowing over its network at any given time. These models are still evolving as service providers develop new strategies for more accurately pricing consumption. ${ }^{449}$

Another key component of enhancing spectral efficiency is active network management to prevent against slow-downs and outages. ${ }^{450}$ Indeed, many carriers manage traffic in such a way so that "large downloads can occur with lower priority, thus not affecting other active users." 451 This allows carriers to assure a minimum quality of service for all customers. ${ }^{452}$ Despite the critical role that such techniques play in assuring a reliable user experience across a carrier's subscriber base, some have proposed limiting or eliminating the ability of a wireless service provider to manage traffic. ${ }^{453}$ For example, as part of a

448 For example, via AT\&T, a BlackBerry user can purchase an unlimited data plan for \$30/month. See BlackBerry Personal Plans, AT\&T.COM, http://www.wireless.att.com/cellphone-service/services/services-

list.jsp?catId=cat $1510007 \&$ catName $=$ BlackBerry $\% \mathrm{C} 2 \% \mathrm{AE}+$ Services (last visited Jan. 1, 2011). Also via AT\&T, a customer can purchase a wireless data card for a laptop and choose between two different plans - one that allows for up to $200 \mathrm{MBs}$ in data usage per month and one that allows for up to 5 gigabytes per month. See DataConnect Plans, AT\&T.COM, http:/www.wireless.att.com/cell-phone-service/cell-phone-plans/data-connectplans.jsp (last visited Jan. 1, 2011).

449 For example, in June 2010 AT\&T became the first wireless provider to offer tiered data pricing for iPhone owners. Low-intensity users can purchase a data plan with a relatively modest monthly data cap for less money than previous flat-rate pricing plans, while high-intensity users can purchase a plan with a higher monthly data cap for slightly more than previous flat-rate pricing plans. See David Lieberman, New AT\&T Smartphone Users Won't Get One-Price Net, USA TODAY, June 2, 2010, at $1 \mathrm{~B}$.

450 BROADBAND EVOLUTION TO 4G, supra note 48, at 7, 52 .

451 Id. at 9.

452 Id

453 Cf. Comcast Corp. v. FCC, 600 F.3d 642 (D.C. Cir. 2010) (holding the Commission did not have ancillary authority over the wireline ISP to regulate its network management practices). This decision prompted a debate to reclassify wireline broadband service. See generally In re Framework for Broadband Internet Service, Notice of Inquiry, 25 F.C.C.R. 7866, 92 (June 17, 2010). The NOI seeks comment on whether to classify Internet service as "information service" under Title I, a "telecommunications service" under Title II, or establish a third way in which the FCC would:

(i) reaffirm that Internet information services should remain generally unregulated; (ii) identify the Internet connectivity service that is offered as part of wired broadband Internet service (and only this connectivity service) as a telecommunications service; and (iii) forbear under section 10 of the Communications Act from applying all provisions of Title II other than the small number that are needed to implement the fundamental universal service, competition and small business opportunity, and consumer protection policies. 
broader network neutrality inquiry, the FCC investigated whether and to what extent network management limitations should be placed on wireless carriers. ${ }^{454}$ Others have suggested that such practices may limit consumer ability to choose the type of content they wish to access on their mobile device. ${ }^{455}$

Many arguments in favor of limiting wireless network management practices, however, fail to account for the unique nature of spectrum and the looming spectrum gap. ${ }^{456}$ Moreover, these arguments do not account for the likely costs of imposing restrictive rules on wireless network managers. Indeed, some have suggested that the costs of imposing restrictions on a wireless carrier's ability to manage their network far outweigh any perceived benefit. ${ }^{457} \mathrm{Con}$ versely, the benefits derived from a carefully managed network outweigh any perceived costs because such practices provide end-users with a reliable experience and access to a growing universe of useful content. ${ }^{458}$ In the absence of additional spectrum for use by wireless service providers, network management and other practices that enhance spectral efficiency are essential to meeting consumer demand for advanced applications and to fostering continued innovation across the wireless market. ${ }^{459}$

Indeed, the current wireless ecosystem has been supported, in part, by careful network management. ${ }^{460}$ Rather than allow the rising tide of data usage to

Id.

A Public Notice released by the FCC in September 2010 sought additional information regarding whether new regulations (e.g., network neutrality rules) were appropriate in light of the "unique" nature of wireless broadband networks. The "unique characteristics" of mobile wireless Internet access services are "related to technology, associated application and device markets, and consumer usage." See Further Inquiry Into Two Under-Developed Issues in the Open Internet Proceeding, GN Docket No. 09-191, WC Docket No. 07-52 (rel. Sept. 1, 2010). The FCC closed this docket and adopted formal net neutrality rules in December 2010. See In re Preserving the Open Internet, Report and Order, GN Docket No. 09191 (rel. Dec. 23, 2010). Many provisions of the final set of rules extend to wireless services. See, e.g., Declan McCullagh, FCC Net Neutrality Rules Reach Mobile Apps, CNET News (Dec. 23, 2010, 7:06 PM), http://news.cnet.com/8301-13578_3-20026581-38.html.

454 In re Preserving the Open Internet Broadband Industry Practices, Notice of Proposed Rulemaking, 24 F.C.C.R. 13064, ๆ 135, 137, at 13113, ๆ 154, at 13117-18 (Oct. 22, 2009).

455 See, e.g., Tim Wu, Wireless Carterfone, I INT'L J. OF COMM. 389, 417 (2009), available at http://ijoc.org/ojs/index.php/ijoc/article/view/152/96 (supporting the imposition of network neutrality requirements on wireless service providers).

456 See In re Preserving the Open Internet; Broadband Industry Practices, Reply Comments of AT\&T Inc., GN Docket No. 09-191, WC Docket No. 07-52, at 10-11 (Apr. 26, 2010) (accessible via FCC Electronic Comment Filing System).

457 See Robert W. Hahn, et al., The Economics of 'Wireless Network Neutrality' 7 (AEIBrookings Joint Ctr. for Regulatory Studies, Working Paper No. RP07-10, 2007), available at http://papers.ssrn.com/sol3/papers.cfm?abstract_id=983111.

$458 I$ Id.

459 See Reply Comments of AT\&T Inc., supra note 439, at 10-11, 104-14.

460 Yochai Benkler, Overcoming Agoraphobia: Building the Commons of the Digitally 
overwhelm networks and suffocate further innovation, wireless network managers have been largely successful in navigating the swell in consumer demand for mobile broadband services by adapting management techniques to new uses. ${ }^{461}$ Such a flexible approach to network management is required as wireless networks and consumer demand continue to mature and evolve. ${ }^{462}$ But for such flexibility, various components of the wireless ecosystem may not have been able to emerge and flourish. For example, the market for add-on applications has evolved from nonexistent in early 2007 to being a multibillion dollar a year market that has made available hundreds of thousands of applications via portals like the App Store and Android Marketplace. ${ }^{463}$ The rapid development of this segment of the wireless marketplace has lowered the barriers to entry into the market for mobile applications and has had important spillover effects on stakeholders across the wireless ecosystem. ${ }^{464}$ Thus, careful network management that is adaptable to new services and applications is essential to nurturing a vibrant wireless ecosystem.

\section{CONCLUSION}

The analyses provided in this article support three general conclusions.

First, wireless broadband has emerged as a vital platform for the delivery of critical new services. ${ }^{465}$ Key innovations in many sectors, including the healthcare, energy, public safety, and education spaces, increasingly rely on wireless broadband networks for the transmission of robust, interactive, and real-time services. As consumer demand for these types of services continues to increase, innovators across the wireless ecosystem have responded by deploying

Networked Environment, 11 HARV. J.L. \& TECH. 287, 323 (1998).

461 See Kevin J. Martin, Balancing Deregulation and Consumer Protection, 17 CoMMLAW CONSPECTUS i, v (2008).

462 See e.g., Robert Hahn \& Peter Passell, Why the FCC Should Stay Out of Data Plan Pricing, CNET NEwS (June 3, 2010, 2:14 PM), http://news.cnet.com/8301-1035_320006760-94.html?tag=mncol;title; Mark Sullivan, AT\&T Wireless CEO Hints at 'Managing' iPhone Data Usage, PCWORLD (Oct. 7, 2009, 7:11 PM), http://www.pcworld.com/article/173320/atandt_wireless_ceo_hints_at_managing_ipone_dat a_usage.html; Ken Denman, Solving Network Congestion Requires Traffic and Demand Management, OPENWAVE BLOG (Aug. 19, 2010), http://www.openwave.com/blog/10-0819/solving-network-congestion-requires-traffic-and-demand-management.

463 App Economy, supra note 70.

464 Apple's Game Changer, supra note 74 (observing that the new market for add-on applications has been a boon to a diverse array of large and small content developers and noting that this new market has forced Apple, a notoriously secretive and closed company, to be more open regarding its application review process and other aspects of its App Store).

465 See supra Part II.B. 
next-generation networks and developing cutting-edge new services. ${ }^{466}$ As a result, wireless service providers require additional spectrum to support continued innovation across the wireless value chain.

Second, the FCC has consistently demonstrated support for the wireless market and for the limitless potential of wireless broadband. To this end, it has adjusted its policies to reflect the growing importance of wireless services like mobile broadband and to facilitate continued network deployments and innovation across the ecosystem. ${ }^{467}$ Moreover, the analysis of the FCC's general approach to spectrum allocation provided in this article reveals that the Commission has historically been responsive to market forces by making additional spectrum available and otherwise adjusting its policies to reflect actual consumer demand. ${ }^{468}$ Perhaps most critically, consumer welfare is maximized when the FCC foregoes the imposition of encumbrances or other usage limitations on the spectrum that it makes available. ${ }^{469}$

Third, the FCC's spectrum allocation policy is comprised of a number of component parts, which include regulations related to spectrum auctions, reallocation of underused or unused portions of the airwaves, the development of a robust secondary spectrum market, and the ability of network engineers to manage traffic congestion. ${ }^{470}$ Changes to one of these policies will likely impact spectrum allocation and utilization across the entire sector. ${ }^{471}$ As such, the FCC and other policymakers should endeavor to understand the full range of costs and benefits associated with spectrum allocation policy reforms.

In order to provide innovators with the spectrum resources and regulatory certainty they need to continue producing and providing cutting-edge services,

466 See supra Part II.B.

467 See, e.g., In re Petition for Declaratory Ruling to Clarify Provisions of Section 332(c)(7)(B) to Ensure Timely Siting Review and Preempt Under Section 253 State and Local Ordinances that Classify All Wireless Siting Proposals as Requiring a Variance, Declaratory Ruling, 24 F.C.C.R. 13994, I 1 (Nov. 18, 2009). The ruling "promotes the deployment of broadband and other wireless services by reducing delays in the construction and improvement of wireless networks." Id.

468 See discussion supra Part II.C.

469 NATIONAL BROADBAND Plan, supra note 11, at 79; See, e.g., Gregory L. Rosston, The Long and Winding Road: the FCC Paves the Path with Good Intentions, 27 TELECOMMS. POL'y 501, 513 (2003); Coleman Bazelon, The Need for Additional Spectrum for Wireless Broadband: The Economic Benefits and Costs of Reallocations, attached to In re Spectrum for Broadband, Comments, GN Docket No. 09-47, GN Docket No. 09-51, GN Docket No. 09-137, at 2 (Oct. 23, 2009); Thomas W. HazletT \& Roberto E. Munoz, What Really Matters In SPECTRUM Allocation Design (2009), available at http://businessinnovation.berkeley.edu/Mobile_Impact/Hazlett-

Munoz_Spectrum_Matters.pdf.

470 See discussion supra Part III.B-C.

471 See supra Part II.D. 
the FCC and other policymakers must:

Appreciate the scope of the looming spectrum gap and the negative impacts on innovation, competition, and consumer welfare that a spectrum shortage would have on consumers, service providers, and all other stakeholders in the wireless ecosystem;

Undertake a comprehensive and rapid spectrum inventory in order to determine which swaths are being underused or unused;

Articulate a more robust policy for reallocating, in a timely manner, those unused or underused portions of the airwaves that are able to support wireless broadband;

Develop policies that support a more robust secondary market for spectrum licenses; and

Allow wireless service providers to carefully manage their networks in order to maximize usage of existing spectrum assets and to provide all consumers with a consistent and reliable user experience.

Policymakers have an opportunity to foster continued experimentation and innovation across the wireless sector by adopting a forward-looking and adaptable framework for spectrum allocation policy that includes mechanisms for providing service providers with the spectrum assets they need to deploy the networks that can support cutting-edge tools and applications. Without a sufficiently flexible policy that can adjust to disruptive innovations and new business models, the vibrant wireless ecosystem that has evolved over the last several years could collapse. 